\title{
COMMENT
}

\section{COURT AWARDED ATTORNEY'S FEES AND EQUAL ACCESS TO THE COURTS \\ TABLE OF CONTENTS}

I. The American Rule of Attorney's Fees: Private Litigation ................... 637

A. Introduction ......................... 637

B. Attorney's Fee Awards in Other Jurisdictions ...... 639

C. American Development ................... 640

D. Exceptions to the American Rule ............ 645

E. An Argument for a New American Rule........ 648

1. Makeweight Opposition .............. 648

2. Likelihood of Penalizing Innocents ....... 649

3. Effect on Litigation ............... 650

a. The Small Claimant ............... 650

b. The Poor Litigant................ 651

4. A Modest Proposal ................ 652

5. Fear of Abuse ................... 654

F. Conclusion .......................... 654

II. Public Interest Litigation and the Private

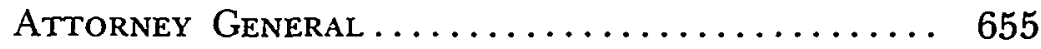

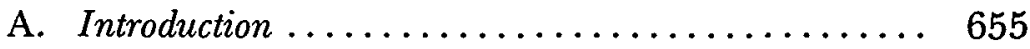

B. Background of Fee Award Theories .......... 658

1. Factors Influencing Their Development ... 658

2. Evolution of Traditional Equitable Grounds 660

C. Development of the Private Attorney General

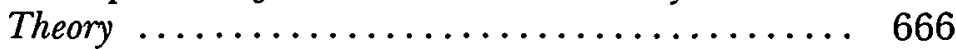

D. Analysis of the Theory ....................670

1. When Is Its Application Appropriate? .... 670

2. Proposed Criteria for Fee Shifting ...... 674

E. Conclusion ...................... 680

III. Fee Awards to Legal Services ............ 681

A. Legal Services' Financial Need ............. 682

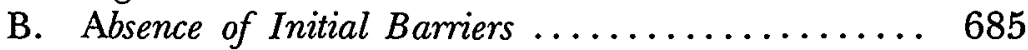

1. Proper Recipient................ 685

2. Competition with the Private Bar...... 686

3. The Client's Obligation to Pay His Attorney ................... 688 
C. Effectuation of Purposes Underlying Fee Awards 689

1. Bad Faith and Obstinacy .............. 689

2. Private Attorney General ............ 692

3. Common Fund ................... 694

4. A Solution ..................... 696

D. Should It Be a Two Way Street? ........... 697

E. Conclusion ........................ 700

IV. Calculating the Fee Award ............ 701

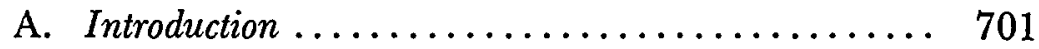

B. The Vagaries of "Reasonableness" ........... 702

C. A Suggested Change .................. 706

1. The Contingency Element ........... 708

2. A Public Interest Factor ............ 711

V. Conclusion ....................... 712

\section{The American Rule of Attorney's Fees: Private Litigation}

\section{A. Introduction}

For generations of American lawyers it has been boldfaced black letter law that in the absence of contrary statutory authority a litigant must, with few exceptions, bear the single greatest cost of asserting his legal rights-his attorney's fees-regardless of the outcome of his action. ${ }^{1}$ This so-called "American Rule"2 of attorney's fees is almost unique in the jurisprudential world. ${ }^{3}$ Indeed, Professor Ehrenzweig has suggested, ${ }^{4}$ a stranger newlyarrived in this country, faced with a small claim, is likely to be astonished when asked by a lawyer for an advance retainer;

${ }^{1}$ See C. McCormick, Handbook on the Law of Damages $\$ \S 60-71$ (1935).

2 The term "American Rule" is used throughout this Comment in the sense just described. The contrasting rule-allowing attorney's fees to be recovered by a successful litigant in the ordinary course-will sometimes be referred to as the "English Rule" for the sake of convenience.

${ }^{3}$ See generally, Report of the Committee on Comparative Jurisprudence, Proceedings ABA International and Comparative Law Section 125 (1953); A. Engelmann, A History of Continental Civil Procedure (7th ed. R. Millar transl. 1927).

In many civil law countries, attorney's fees are today awarded to a prevailing party as a matter of right and are controlled by sets of tariff schedules. For an analysis of the law of Germany, see Shartel \& Wolff, Civil Justice in Germany, 42 Mich. L. REv. (1944). For a discussion of the award of fees in South Africa, see Rubin \& Stanford, The Sources of South-African Law of Costs, 65 S. AFr. L.J. 387 (1948). For Swiss and pre-communist Hungarian provisions, see Baeck, Imposition of Legal Fees and Disbursement of Prevailing Party upon the Losing Party-Under the Laws of Switzerland, REPORT OF THE CoMmitTeE on Comparative Procedure and Practice, Proceedings aba International and Comparative Law Section 117, 124. (1962); Dietz, Payment of Court Costs by the Losing Party Under the Laws of Hungary, id. 131. (1966).

${ }^{4}$ Ehrenzweig, Reimbursement of Counsel Fees and the Great Society, 54 CAL. L. Rev. 792 
anywhere else in the world the lawyer would expect to obtain his fees from the defendant. ${ }^{5}$

Legal commentators have in recent years expressed amazement, disappointment and outrage at the American system's persistence in its eccentricity, despite voluminous collected evidence of the inequities and shortcomings inherent in its approach to attorney's fees. ${ }^{6}$ Most scholarly criticisms have pointed to the English system, which generally awards reasonable attorney's fees to a prevailing litigant, ${ }^{7}$ and have compared the relative success of our own to make whole the wronged litigant; 8

${ }^{5} I d .792$.

${ }^{6}$ For a good analysis of the inequities of the American Rule, especially in reference to the small claim, see Ehrenzweig, supra note 4. See also Avilla, Shall Counsel Fees Be Allowed?, 13 CAL. ST. B.J., Mar., 1938, at 42; Goodhart, Costs, 38 YAlE L.J. 849 (1929); Kuenzel, The Attorney's Fee: Why Not a Cost of Litigation?, 49 Iowa L. REv. 75 (1963); Mause, Winner Takes All: A Re-Examination of the Indemnity System, 55 IowA L. REv. 26 (1969); McCormick, Counsel Fees and Other Expenses of Litigation as an Element of Damages, 15 Minn. L. Rev. 691 (1931); Stirling, Attorney's Fees: Who Should Bear the Burden?, 41 CAL. ST. B.J. 874 (1966); Stoebuck, Counsel Fees Included in Costs: A Logical Development, 38 U. Colo. L. Rev. 202 (1966); Note, Attorney's Fees, 43 Miss. L.J. 238 (1972); Note, Attorney's Fees as an Element of Damage, 15 U. CinN. L. Rev. 313 (1941); Note, Attorney's Fees: Where Shall the Ultimate Burden Lie?, 20 VAND. L. REv. 1216 (1967) [hereinafter cited as Burden]; Note, Distribution of Legal Expense Among Litigants, 49 YALE L.J. 699 (1940) [hereinafter cited as Distribution].

${ }^{7}$ Today costs and counsel fees are essentially governed by The Supreme Court Costs Rules of 1959 and attached appendices. 1 I. JACOB, P. ADAMS, J. NEAVE, \& K. MCGUfFIE, The Annual Practice 1999/210-2000 (1966) [hereinafter cited as Rules].

An exhaustive schedule of cost items is attached to the Rules. Id., app. 2 at 1999/3 19-46. Although there has been some litigation over questions arising from the Rules and schedules and particular items omitted or included, see, e.g., In re Breeden's Settlement Trusts, [1964] I W.L.R. 901 (concerning awards of fees for leading counsel); Simpsons Motor Sales Ltd. v. Hendon Corp., [1965] 1 W.L.R. 112 (on calculating a proper fee for preparation of a brief); Lawson v. Tiger, [1953] 1 W.L.R. 503 (defining time spent at trial), there is little doubt that counsel fees are generally awarded to the prevailing party unless considerations of equity require otherwise.

Costs in the Supreme Court are taxed by three kinds of officers, a taxing master, a registrar of the principal probate registry and the Admiralty registrar, RuLEs 12-(1), who are empowered to tax "the costs of or arising out of any cause or matter in the Supreme Court." Id. 12-(1)-(a). The discretion of the taxing master in awarding costs is considera. ble, although limited to "necessary or proper" items, id. 28-(2). "Proper" has been interpreted to include not only strictly necessary costs, but also those which are reasonably incurred for the purpose of the litigation. See Societe Anonyme Pecheries Ostendaises v. Merchants Marine Ins. Co., [1928] 1 K.B.750.

To receive the appropriate amount of cost recovery, the winning solicitor sends his bill to the losing solicitor. If a dispute arises and no agreement can be reached, the bill is then sent to a master, who "taxes" it, disallowing or reducing any items he considers unnecessary or excessive under the circumstances. The cost of taxing the bill is also covered by a rule: if less than one-sixth of the bill is disallowed, the party challenging the bill must bear that cost. If, however, the bill is reduced by more than one-sixth, the party offering the bill must pay.

For a complete discussion of the inner workings of the English practice see $R$. Jackson, The Machinery of Justice in ENGland (5th ed. 1967).

${ }^{8}$ One commentator persuasively reasons that "a legal system which refuses an innocent party full compensation for expenses incurred in asserting his right necessarily denies him full redress for the injury he has suffered." Burden supra note 6, at 1216. Similarly, the Massachusetts Judicial Council has posed a provocative question:

On what principle of justice can a plaintiff wrongfully run down on a public highway recover his doctor's bill but not his lawyer's bill? And on what principle of justice is a defendant who has been wrongfully haled into court made to pay out of his own pocket the expense of showing that he was wrongfully sued? 
to enable lower- and middle-class litigants to bring meritorious small claims; ${ }^{9}$ or to prevent wealthier litigants from manipulating harassment and delay to threaten spiraling costs and force opponents-even those with just claims or defenses-into submission. ${ }^{10}$

The American Rule for the recovery of attorney's fees has been challenged unavailingly on numerous occasions in both state and federal courts. ${ }^{11}$ The courts, while adamantly adhering to the Rule, have continually failed to critically evaluate the justifications for its perpetuation. Since some writers have described the American Rule as merely a "historical accident,"12 this tendency to regard it uncritically as a universal truth is particularly unfortunate.

\section{B. Attorney's Fee Awards in Other Jurisdictions}

In virtually every country outside the United States, courts have awarded and continue to award attorney's fees to the prevailing party in ordinary lawsuits as an item of compensatory damage or cost necessary to a full and just recovery. In late Roman law, under the guiding hand of Justinian, the duty of paying legal costs, including even such extrajudicial expenses as traveling costs and advocate's fees, ${ }^{13}$ functioned as a penalty for groundless litigation. In French civil practice the "general principle" was early established that a losing litigant should "be adjudged to pay all costs, without exception." 14 And according to the ancient Sea Law in Sweden, a losing party was required to reimburse a successful litigant for his reasonable outlays in the action. A judgment was, in fact, deemed incomplete without a determination of the award of costs; none was to be denied "his reasonable expenses."15

According to Pollock and Maitland, before the time of Edward I, although it was "highly probable" that in some cases a successful plaintiff "might often under the name of 'damages' obtain a compensation which would cover the costs of litigation as well as all other harm that he had sustained,"16 this was usually not the case in an action for land, in which neither

First Report Of The Judicial Council of Massachusetts, 11 Mass. L.Q. 1, 64 (1925).

See also Kuenzel, supra note 6; Stoebuck, supra note 6.

${ }^{9}$ See, e.g., Cheatham, A Lauyer When Needed: Legal Services For The Middle Classes, 63 Colum. L. REv. 973 (1963); Ehrenzweig, supra note 4; Note, Providing Legal Services For the Middle Class In Civil Matters, 26 U. PITT. L. REv. 811 (1965).

${ }^{10}$ See, e.g., Avilla, supra note 6.

11 See notes 30-46 infra \& accompanying text.

${ }^{12}$ E.g., Goodhart, supra note 6.

${ }^{13}$ A. Engelmann, supra note 3, at 403.

${ }^{14}$ Id. 726 (emphasis in original).

${ }^{15}$ Id. 859-60.

${ }^{16} 2$ F. Pollock \& F. Maitland, The History of English Law 597 (2d ed. 1968). 
damages nor costs could be gotten. It was thus only under statute that a victorious defendant could claim costs. ${ }^{17}$ Indeed, no costs were allowed to either party at common law. If the plaintiff failed to recover, he was amerced (punished by a fine) for his false complaint (pro falso clamore). If the plaintiff did recover, the defendant-though in misericordia for unjustly detaining the plaintiff's debt-was not additionally taxed with the expenses of litigation. ${ }^{18}$ Public opinion, however, gradually stirred by the consequent hardships of litigation, resulted in enactment of the Statute of Gloucester, ${ }^{19}$ a 1278 legislative fiat grounded in the theory that the damages allowed against a defendant in misericordia were insufficient either to discourage the bringing of improvident defenses or to make the plaintiff whole. Although the statute dealt specifically only with the cost of the writ in actions for land, it was liberally interpreted to provide for all reasonable legal expenditures of plaintiffs, including their attorney's fees. ${ }^{20}$ Provision for awarding attorney's fees to prevailing defendants came more slowly, but was accomplished by $1606 .{ }^{21}$

\section{American Development}

The English practice of allowing fee awards to a prevailing litigant, one option clearly available to the legal establishment in colonial America, was quickly rejected. Curiously enough, it appears that early courts in colonial America routinely awarded all costs, including the fees of counsel, to the successful litigant. ${ }^{22}$ One explanation offered for the historic abandonment of this practice is that later settlers soon developed hostility and distrust for legal practitioners. This colonial attitude, toward lawyers has been well described:

In every one of the Colonies, practically throughout the Seventeenth Century, a lawyer or attorney was a character of disrepute and of suspicion, of whose standing

\footnotetext{
${ }^{17}$ Id.

${ }^{18}$ Day v. Woodworth, 54 U.S. (13 How.) 363, 372 (1851). See also Hullock, THE LAw of Costs 1 (1793).

${ }_{19}$ Watson, A Rationale of The Law Of Costs, 16 CENT. L.J. 306 (1883) (citing 6 Edw. I, ch. 1 (1278)).

${ }^{20}$ Id. 307.

214 Jac. I, ch. 3 (1606). For an excellent, insightful history of the development of modern English practice in taxing costs against a losing litigant, see Goodhart, supra note 6 , at 851-54. Much historical material contained in this Comment has been liberally borrowed from this widely cited source.

For a brief overview of the mechanics of modern British practice in awarding attorney's fees, see note 7 supra.

${ }_{22}$ See, e.g., Evrell v. Bradstret, 3 Records Of The Court Of Assistants, Colony OF The Massachusetts Bay 163 (1666) (published in 1928); Clarke v. Davis, $i d$. at 130 (1662); Hakins v. Gooden, id. at 86 (1660). There appears, however, some split in opinion whether such practice was typical of even the mid-seventeenth century. Compare Distribution, supra note 6, with Ehrenzweig, supra note 4.
} 
or power in the community the ruling class... was extremely jealous. In many of the Colonies, persons acting as attorneys were forbidden to receive any fee .....23

Since lawyers were regarded with such disdain, it is not altogether surprising that early colonists did not choose to promote the economic health of the profession by allowing courts to award attorney's fees to a prevailing party. Distrust of the American bár was aggravated by the belief that the corpus of law was composed not of technical elegances, but of simple rules easily comprehensible by anyone, and the suspicion that a lawyer was an unnecessary luxury.

The frontier experience was, moreover, extraordinarily influential in the development of early American jurisprudence; ${ }^{24}$ as Dean Pound explained, the spirit of the American pioneer, who scorned the notion of scientific law and a learned bar, left an indelible mark on the development of both procedural and substantive law. ${ }^{25}$ The popular view of the solitary folk-hero fighting for his rights ${ }^{26}$ played a significant role in the emergence of the unique American Rule.

Furthermore, in the years immediately following the Revolution, resentment developed in this country for anything English. In fact, the legal system so reacted against John Bull that in the courts of New Hampshire there arose a rule against English citations. ${ }^{27}$ This conscious attempt to purge English traditions from the American legal system, taken with fierce frontier individualism, made it unlikely that America would adopt a rule which routinely awarded attorney's fees.

Professor Ehrenzweig has, however, suggested that the American departure from English fee practice may have occurred for less rational reasons than those suggested above. As the frontier moved westward, he notes, American life became increasingly centralized, and less and less emphasis was placed on individualism. As uniformity and consistency of law became a major goal of reformers, disrespect for legal practitioners diminished; as the law grew more complex, their services were recognized as a necessity and not a luxury. The complete rejection of English jurisprudence which marked the early postRevolutionary years abated as the wounds of war healed.

${ }^{23}$ C. WARREN, A History of the AMerican Bar 4 (1911).

${ }^{24}$ R. Pound, The Spirit of The Common Law 112-38 (1921).

${ }^{25}$ Id. 124.

${ }^{26}$ Id. 145 .

${ }^{27}$ Id. 117. Dean Pound explains: "The citation of English decisions in the opinions of the courts ... greatly exasperated the radical element. What were these precedents but the rags of despotism, who were the judges that rendered them but tyrants, sycophants, oppressors of the people and enemies of liberty." Id. 116-17. 
Reflecting these societal changes, the early nineteenth-century legal community, according to Ehrenzweig, tried the British rule. In many states, legal fees were-under statutory authority ${ }^{28}$ - awarded to the prevailing party as an item of cost. Such fees were, however, strictly controlled, never adjusted to meet realistic needs, and, even when first adopted, never more than nominal in amount. Consequently, Professor Ehrenzweig suggests, it is legislative abandonment which has, over time, resulted in the American Rule, a rule therefore best described as merely a "historical accident." 9

Often taken for a maxim graven in stone, the American Rule may not only be an historical legislative accident, but may as well owe its continued existence to a fundamental error in the judicial process. For judicial preoccupation with stare decisis, not judicial acceptance of the Rule itself, is primarily responsible for the present American Rule of attorney's fees.

In what appears to be the first Supreme Court statement on the subject, the Court in Arcambel v. Wiseman ${ }^{30}$ rejected an argument that a requested $\$ 1600$ attorney's fee ought to be included as part of the recovery as a legitimate item of damage necessary to make the prevailing litigant whole. While admitting that its decision was not wholly satisfactory, the Court chose precedent over policy, asserting: "The general practice of the United States is in oposition [sic] to [the allowance of attorney's fees] ... . and even if that practice were not strictly correct in principle, it is entitled to the respect of the court, till it is changed, or modified, by statute."31

This conservative reasoning typifies the judicial analysis which has followed, to justify adherence down to the present to a rule of law that was arguably "not strictly correct in principle" nearly two hundred years ago.

In 1851 the Supreme Court was again, in Day v. Woodworth, ${ }^{32}$ given an opportunity to pass on the legitimacy of awarding attorney's fees as an item of compensatory damages. Again it failed to amend, overturn or even explore the wisdom of

${ }_{28}^{28}$ See, e.g., Act of Dec. 23, 1820, ch. 48, § 2, 8 N.H. Laws 1003, 1006; Act of May 14, 1840 , ch. 386, §§ 2, 3, [1840] N.Y. Laws 327-30; Act of Feb. 22, 1821, ch. 4954, § 2, [1821] Pa. Laws 367.

${ }_{29}$ Ehrenzweig, supra note 4, at 799. Professor Ehrenzweig insists that:

It was this mistake probably that caused lawyers and courts, when rising living costs began to obscure the real purpose of the statutory amounts of "costs," gradually to forget the meaning of those amounts. And it was this process of gradual forgetting rather than a deep-seated moral argument that has apparently caused the abolition of the prevailing party's right to the recovery of his

Id. 799 . counsel fees.

${ }^{30} 3$ U.S. (3 Dall.) 306 (1796)

31 Id. at 306.

${ }^{32} 54$ U.S. (13 How.) 363 (1851). 
the American Rule. Admitting that there was "no doubt" that in America "legal taxed costs are far below the real expenses incurred by the litigant," the Court simply concluded that such expenses were "all the law allows." 33

By 1872, although continuing to cite to Arcambel and Day when denying attorney's fee awards, specifically in the patent area, ${ }^{34}$ the Court seems to have felt compelled to justify maintaining the American Rule. Apparently adopting Dean Wigmore's "sporting theory" of early American justice, ${ }^{35}$ the Court asserted that the Rule placed " $[t]$ he parties ... upon a footing of equality." 36 The Court also suggested that the lack of any "fixed standard by which the honorarium can be measured"37 justified the American Rule; the Court foresaw a possibility of "animated and protracted" litigation over the question of the "proper amount" and noted the "delicacy" required in "scal[ing] down the charges." 38 Furthermore, fear of abuse seemed to the Court to justify disallowance of all fee awards. It noted with apparent alarm that "[s]ome counsel demand much more," that "[s]ome clients are willing to pay much more," and that "[m]ore counsel may be employed than necessary." 39 For all of these reasons, the Court concluded that the "principle of disallowance rest[ed] on a solid foundation," and that a contrary rule would be "forbidden by the analogies of the law and sound public policy." 40

Just six years later, the Court again spoke directly to the issue of fee awards. ${ }^{41}$ This time it offered a novel defense of the American Rule in an action for malicious prosecution: attorney's fees could not be included as normal items of damages since they were not, the Court suggested, proximately caused by the actions of the defendant; it was not foreseeable that one would obtain the aid of a lawyer when criminally prosecuted. ${ }^{42}$

More recently the Court has continued to embrace the rule first announced in Arcambel. Some additional justifications for its perpetuation were suggested in Fleischmann Distilling Corp. $v$.

${ }^{33} I d$. at 372 (emphasis added).

${ }^{34}$ Oelrichs v. Spain, 82 U.S. (15 Wall.) 211, 230, 231 (1872).

${ }^{35}$ See R. Pound, supra note 24 , at 127 . Dean Pound describes the sporting theory as the idea that "justice is a game to be played to the bitter end," in which the combatants should be put on an entirely equal basis. See also Saint Peter's Church v. Beach, 26 Conn. 355 (1857).

${ }^{36}$ Oelrichs v. Spain, 82 U.S. (15 Wall.) 211, 231 (1872).

${ }^{37} I d$.

${ }^{38} I d$.

${ }^{39} I d$.

${ }^{40} I d$.

${ }^{41}$ Stewart v. Sonneborn, 98 U.S. 187 (1878).

${ }^{42}$ The Court explained that "[t]he fees of counsel in prosecuting this case" were not natural consequences of the defendants' actions "in suing out the decree and warrant in bankruptcy. They were not what the defendants ought to have foreseen." Id. at 197. 
Maier Brewing Co. ${ }^{43}$ In an 8-1 decision ${ }^{44}$ delivered by Chief Justice Warren, the Court asserted, in support of the American Rule, that "since litigation is at best uncertain one should not be penalized for merely defending or prosecuting a lawsuit," that "the poor might be unjustly discouraged from instituting actions to vindicate their rights if the penalty for losing included the fees of their opponents' counsel," and that "the time, expense, and difficulties of proof inherent in litigating the question of ... reasonable attorney's fees would pose substantial burdens for judicial administration." 45 In an even more recent Court statement on attorneys' fees Mr. Justice Brennan cited the American Rule almost offhandedly, merely stating that "the traditional American rule ordinarily disfavors the allowance of attorneys' fees ...." 46

Thus the Supreme Court has fully adopted a rule first announced in 1796 by a Court which admitted the possible unsoundness of its own position. While justifications have concededly been offered-in its continued support over the years, the courts have tended to rely heavily on early cases as compelling and authoritative support for the rule, without ever examining frontally its essential underpinnings. ${ }^{47}$

\footnotetext{
43386 U.S. 714 (1967).

${ }^{44} \mathrm{Mr}$. Justice Stewart dissented on a separate ground.

45386 U.S. at 718 (citations omitted).

${ }^{46}$ Hall v. Cole, 412 U.S. 1, 4 (1973).
}

${ }^{47}$ The state courts too have examined the attorney's fee issue through somewhat darkened lenses. For randomly selected examples of instances of state court denials of fee awards either as an item of compensatory damage or as an item of cost in the absence of statutory or equitable authority, see Penney v. Pritchard, 255 Ala. 13, 49 So. 2d 782 (1950); Le Favve v. Dimond, 46 Cal. 2d 868, 299 P.2d 858 (1956); Reter v. Davenport, R.I. \& N.W. Ry., 243 Iowa 1112, 54 N.W.2d 863 (1952); Ablah v. Eyman, 188 Kan. 665, 365 P.2d 181 (1961); Winkler v. Roeder, 23 Neb. 706, 37 N.W. 607 (1858).

Pennsylvania experience seems for the most part to reflect the judicial history of other states which have passed upon the question. In one early and aberrational Pennsylvania action on the case, in which a father sued for the loss of his son's services caused by the youth's broken leg, Wilt v. Vickers, 8 Watts 227 (Pa. 1839), the court reasoned that the plaintiff should "recover in damages whatever sum may be requisite to compensate him for his loss occasioned by the conduct of the defendant," and that "compensation cannot be made without taking into the estimate the trouble and expense incurred by the plaintiff in prosecuting his suit," since if the plaintiff were allowed only damages equal to the actual loss of service, "he, instead of being compensated, would be a loser, notwithstanding his right to a recovery." Id. at 235-36. Such analysis, reflecting the theory that one ought to be made whole through the judicial process, see, e.g., Stoebuck, supra note 6 , was overruled just nine years later by a case bottomed in what might best be termed judicial cynicism, Good v. Mylin, $8 \mathrm{~Pa}$. 51 (1848), with Chief Justice Gibson asserting that it was a "fallacy to suppose that every successful plaintiff has a right to be made whole by a verdict which is, at best, only an approximation to perfect justice." The Chief Justice was not troubled by the recognition that " $[t]$ here is many a right . . not worth the trouble and expense of enforcing it," since " $[t]$ o pay for expenses and trouble, in order to make it valuable, would open a field of inquiry often more extensive than the issue raised by the pleadings, and make it the principal battleground." Id. at 56. Additionally Chief Justice Gibson expressed a fear of possibly protracted litigation in much the manner of the Supreme Court some three years later, see text accompanying note 37 supra.

In another noteworthy case, Chief Justice Gibson addressed the possible abuses of a system in which attorney's fees might be routinely awarded, $c f$. text accompanying note 


\section{Exceptions to the American Rule}

Though black lettered and enduring, the American Rule is not without its exceptions. Even absent express statutory authority, for example, there exists in equity judicial license to grant attorney's fees in particular cases. In one early twentieth-century Eighth Circuit case, Guardian Trust Co. v. Kansas City Southern Railway Co., ${ }^{48}$ Judge Booth found this equity power to have originated in early English statutory law, ${ }^{49}$ and to extend to cases in which "gross charges of fraud and misconduct have been made and not sustained"; in which "the main ground of the suit is false, unjust, vexatious, wanton, or oppressive" or in which "a fiduciary relationship exists."50

In this country, the Supreme Court followed the English practice in promulgating the Rules of Practice for the Courts of Equity of the United States, ${ }^{51}$ which provide that: "In all cases where the rules prescribed by this Court, or by the Circuit Court, do not apply, the practice of the Circuit Courts shall be regulated by the practice of the High Court of Chancery in England."52 Thus the federal courts have since their inception ${ }^{53}$ been empowered to award costs. Probably in deference to the American Rule, however, courts of equity have been conservative in the exercise of that inherent power in private litigation. Current experience indicates that fee awards will be granted "only in exceptional cases and for dominating reasons of justice."54 Thus equity has-except in admiralty suits in which attorney's fees have historically been viewed as an item of compensatory damages ${ }^{55}$ - typically awarded attorney's fees only in extraor-

38 supra, expressing concern that if fees were allowed, "[c]lients would pay liberally out of the pockets of their adversaries ...." Alexander v. Herr's Ex'rs, 11 Pa. 537, 539 (1849). See also Winton v. Morrs, $87 \mathrm{~Pa} .77$ (1878).

Like the United States Supreme Court, moreover, Pennsylvania courts over time neglected to provide reasons for the existence of their rule regarding attorney's fees; subsequent cases began to depend purely on hoary precedents. In one not atypical late 19th century case, the court cited Alexander as having so "fully discuss[ed] this question," that it felt "nothing further" needed be added. Commonwealth v. Meyer, $170 \mathrm{~Pa} .380$, 384, 32 A. 1044, 1045 (1895). As time passed, decisions adverted to the settled rule denying counsel fees. See, e.g., Kling Appeal, 433 Pa. 118, 249 A.2d 552 (1969); Drummond v. Drummond, 414 Pa. 548, 200 A.2d 887 (1964); Smith v. Equitable Trust Co., 215 Pa. 413, 64 A. 591 (1906).

4828 F.2d 233 (8th Cir. 1928).

${ }^{49} I d$. at 240 .

${ }^{30} I d$. at 241 .

5120 U.S. (7 Wheat.) v (1822).

52 Equity R. 33 , id. at xiii.

${ }^{53}$ For a compilation of authorities in which the equity power has been approved and followed by early federal courts, see Guardian Trust Co. v. Kansas City S. Ry. Co., 28 F.2d 233, 241 n.2 (8th Cir. 1928).

${ }^{54}$ Sprague v. Ticonic Nat'l Bank, 307 U.S. 161, 167 (1939). See also Hall v. Cole, 412 U.S. 1, 5 (1973); Mills v. Electric Auto-Lite Co., 396 U.S. 375, $391-92$ (1970); Fleischmann Distilling Corp. v. Maier Brewing Co., 386 U.S. 714, 718 (1967) (overriding considerations of justice may compel such a result).

${ }^{55}$ See, e.g., Vaughan v. Atkinson, 369 U.S. 527, 530-31 (1962) (due to respondent's "willful and persistent" recalcitrance). 
dinary cases, such as a civil contempt action for willful disobedience to a court order, ${ }^{56}$ or cases in which a party's actions can be characterized as clearly oppressive or vexatious. ${ }^{57}$ The underlying theory behind the award of fees in equity is, in any event, "punitive."58

As a corollary to the award of attorney's fees in exceptional cases in equity, the courts have created a "common fund" exception to the American Rule and awarded fees to a single party acting on behalf of a larger class. Courts have found it fundamentally unjust to tax the representative of the class, who has worked for others as well as himself, with an attorney's fee which has benefited others who have incurred no such expense, ${ }^{59}$ and have thus awarded the prevailing party his reasonable costs.

In addition, Congress has given specific statutory authorization for awarding "reasonable" attorney's fees in certain classes of private litigation to assist the enforcement of certain laws, encouraging the bringing of particular types of claims and discouraging unjust and unfounded defenses. Reasonable fees are thus awarded in antitrust cases, ${ }^{60}$ under the Communications Act, ${ }^{61}$ for violations of the copyright laws, ${ }^{62}$ under the Fair Labor Standards Act, ${ }^{63}$ for certain violations of the interstate commerce laws ${ }^{64}$ under the Merchant Marine Act, ${ }^{65}$ in cases brought under the Packers and Stockyards Act, ${ }^{66}$ under the patent laws, ${ }^{67}$ for

${ }^{56}$ See, e.g., Toledo Scale Co. v. Computing Scale Co., 261 U.S. 399, 426 (1923). But see Lichtenstein v. Lichtenstein, 481 F.2d 682 (3d Cir. 1973).

${ }^{57}$ See, e.g., Universal Oil Prods. Co. v. Root Ref. Co., 328 U.S. 575 (1946); Schlein v. Smith, 160 F.2d 22 (D.C. Cir. 1947) (gross fraud); Cleveland v. Second Nat'l Bank \& Trust Co., 149 F.2d 466 (6th Cir.), cert. denied, 326 U.S. 775 (1945); In re Swartz, 130 F.2d 229 (7th Cir. 1942) (oppressive motions). For fees awarded as compensatory damages in trademark cases against parties guilty of bad faith, fraud or unconscionable conduct, see Admiral Corp. v. Penco, Inc., 203 F.2d 517 (2d Cir. 1953); Aladdin Mfg. Co. v. Mantle Lamp Co., I 16 F.2d 708 (7th Cir. 1941). For a depiction of the broad expansion of this "bad faith" exception in public interest litigation, see notes 157-63 infra \& accompanying text.

${ }^{58}$ Hall v. Cole, 412 U.S. 1, 5 (1973). For an analysis of a unique stance taken by New Jersey courts, see Lynch, The New Jersey Supreme Court And The Counsel Fees Rule, 4 SETON Hall L. Rev. 19 (1972).

${ }^{59}$ Trustees v. Greenough, 105 U.S. 527, $533-37$ (1882). See also Rude v. Buchhalter, 286 U.S. 451 (1932) (suit to preserve a trust fund); Harrison v. Perea, 168 U.S. 311 (1897) (suit to recover assets of decedent's estate); Angoff v. Goldfine, $270 \mathrm{~F} .2 \mathrm{~d} 85$ (1st Cir. 1959) (stockholder's suit); Washington Gas Light Co. v. Baker, 195 F.2d 29 (D.C. Cir. 1951) (consumer's suit). The notion of what defines a common fund was extended in Mills v. Electric Auto-Lite Co., 396 U.S. 375, 392-97 (1970); Sprague v. Ticonic Nat'l Bank, 307 U.S. 161, 166-67 (1939). See also Note, The Allocation Of Attorney's Fees After Mills v. Electric Auto-Lite Co., 38 U. CHI. L. Rev. 316 (1971); notes 217-25 infra \& accompanying text.

${ }^{60} 15$ U.S.C. $\S 15(1970)$.

${ }^{61} 47$ U.S.C. $\S 206(1970)$.

6217 U.S.C. \& $116(1970)$.

6329 U.S.C. $\$ 216(\mathrm{~b})(1970)$.

6449 U.S.C. $\$ \S 8,908(b)(1970)$.

6546 U.S.C. \& 1227 (1970).

${ }^{66} 7$ U.S.C. $\$ 210(\mathrm{f})(1970)$.

${ }^{67} 35$ U.S.C. $\S 285$ (1970). 
actions under the Perishable Agricultural Commodities Act, ${ }^{68}$ under the Railway Labor Act, ${ }^{69}$ for violations of the Securities Exchange Act, ${ }^{70}$ under the Servicemen's Readjustment Act, ${ }^{71}$ and the Trust Indenture Act. ${ }^{72}$ A twenty dollar docket fee also is generally awarded to the prevailing party. ${ }^{73}$

In state courts, attorney's fees may be awarded to a wife, whether or not successful, in a divorce action, in the discretion of the trial court. ${ }^{74}$ Attorney's fees have also been awarded to a litigant forced to defend an action as the result of the wrongful conduct of others. For example, a land purchaser with covenants of title whose title is successfully challenged by holders of adverse interests may recover fees in a subsequent action against his warrantor. ${ }^{75}$ Similarly, at tort law, fees are recoverable by an innocent maliciously prosecuted. ${ }^{76}$ These latter state common law exceptions to the American Rule appear-unlike the divorce exception-to be grounded in the concepts of punishment and deterrence of misconduct and oppressiveness.

In Alaska, recovery of attorney's fees is allowed generally by statute. This unique practice arises from a statute enacted by Congress in 1900, ${ }^{77}$ for which there is a dearth of available legislative history. One can at best surmise that Congress may have wished to encourage attorneys to relocate to the Alaskan territory, or that it felt that the law could best be enforced if attorney's fees were routinely awarded. For whatever historic reason the unique Alaskan rule was born, Alaska has preserved the rule upon attaining statehood, and Alaskan courts continue to authorize attorney's fees ${ }^{78}$ according to an official schedule. ${ }^{79}$

\footnotetext{
687 U.S.C. $\$ 499 \mathrm{~g}(\mathrm{~b})$ (1970).

6945 U.S.C. \& $153(\mathrm{p})(1970)$.

${ }^{70} 15$ U.S.C. $\$ \S 78 \mathrm{i}(\mathrm{e}), 78 \mathrm{r}(\mathrm{a})(1970)$.

7138 U.S.C. \& 1822 (b) (1970).

7215 U.S.C. \& 77www(a) (1970).

7328 U.S.C. \& 1923(a) (1970).
}

${ }^{74}$ Cf. Brandel v. Brandel, 69 Ill. App. 2d 264, 216 N.E.2d 21 (1966) (dictum); Bahre v. Bahre, 140 Ind. App. 246, 211 N.E.2d 627 (1965) (dictum); Clifford v. Clifford, 354 Mass. 545, 238 N.E.2d 522 (1968) (dictum); Hammond v. Hammond, 210 Pa. Super. 386, 233 A.2d 628 (1967) (dictum). See also Shima v. Shima, 139 F.2d 533 (D.C. Cir. 1943).

${ }_{75}$ See, e.g., Seitz v. People's Sav. Bank, 140 Mich. 106, 103 N.W. 545 (1905).

${ }^{76} C f$. Biggans v. Hajoca Corp., 94 F. Supp. 593 (E.D. Pa.), aff', 185 F.2d 982 (3d Cir. 1950).

77 Act of June 6, 1900, ch. 786, §509, 31 Stat. 415.

${ }^{78}$ Al.ASKA STAT. $\S 09.60 .010$ (1972) reads: "Except as otherwise provided by statute, the supreme court shall determine by rule or order what costs, if any, including attorney fees, shall be allowed the prevailing party in any case.

${ }^{79}$ Alas. R. Crv. P. 82(a) provides:

(1) Unless the court, in its discretion, otherwise directs, the following schedule of attorney's fees will be adhered to in fixing such fees for the party recovering any money judgment therein, as part of the costs of the action allowed by law: 
Nevada authorizes the award of counsel fees in cases in which the plaintiff has sought a recovery of under $\$ 10,000.00 .^{80}$ The legislative history of this rule is lacking, although it appears to have its origins in a belief that larger claims are likely brought by litigants more able to afford litigation and to pay their own attorneys. ${ }^{81}$

\section{E. An Argument for a New American Rule}

Taken one by one, the purported justifications for the continued existence of the American Rule add up to little in today's world, in which rugged individualism is a dwindling commodity, law is no longer-if it ever was-a collection of simple rules for judges to administer "according to their common sense and the light of nature,"82 and an attorney is not a luxury but a necessity for the successful maintenance of a cause of action or defense. ${ }^{83}$

\section{Makeweight Opposition}

Certain historical objections to implementation of a system of universal indemnity for attorney's fees seem little more than frivolous in 1974. The objection that the expense of counsel is too remote and unforeseeable to be includible as an item of damage ${ }^{84}$ for example, seems easily dispensed with as as best

Attorney's Fees in Average Cases

$\begin{array}{lllll}\text { First } & \$ 2,000 & 25 \% & 20 \% & 15 \% \\ \text { Next } & 3,000 & 20 \% & 15 \% & 12.5 \% \\ \text { Next } & \$ 5,000 & 15 \% & 12.5 \% & 10 \% \\ \text { Over } & \$ 10,000 & 10 \% & 7.5 \% & 5 \%\end{array}$

Should no recovery be had, attorney's fees for the prevailing party may be fixed by the court as a part of the costs of the action in its discretion, in a reasonable amount.

(2) In actions where the money judgement is not an accurate criteria for determining the fee to be allowed to the prevailing side, the court shall award a fee commensurate with the amount and value of legal services rendered.

See also Alaska STat. § 09.60 .015 (1972).

${ }^{80}$ NEV. REv. STAT. $\$ 18.010(3)$ (1971) provides:

The court may make an allowance of attorney's fees to:

(a) The plaintiff as prevailing party when the plaintiff has not recovered more than $\$ 10,000$; or

(b) The counterclaimant as prevailing party when he has not recovered more than $\$ 10,000$; or

(c) The defendant as prevailing party when the plaintiff has not sought recovery in excess of $\$ 10,000$.

${ }_{81}$ Letter from Melvin D. Close, Jr., member of the Nevada bar, to the University of Pennsylvania Law Review, Aug. 24, 1973, on file in Biddle Law Library, University of Pennsylvania.

${ }_{82}$ R. Pound, supra note 24 , at 113.

${ }^{83}$ The Supreme Court has confirmed this necessity with regard to the criminal defendant, for whom access to the assistance of counsel is required by the Constitution. Gideon v. Wainright, 372 U.S. 335 (1963).

${ }^{84}$ See note 42 supra \& accompanying text. 
based upon antiquated assumptions. Today, when an attorney is a basic necessity to the pursuit of legal redress, it would--for better or for worse-require rare myopia for anyone to fail to foresee that a litigant will be represented by an attorney, even if the cost of the latter's services may be less than precisely foreseeable.

Another assertion, that to allow judges wide discretion in awarding fees is contrary to the "general American conception of a judiciary bound by fixed rules," 85 seems undeserving of detailed exposition and palpably incorrect, for our judicial system is replete with examples of important judicial discretion, particularly in equity where discretion is the rule. ${ }^{86}$

Similarly, the attitude that the legal system can only remotely approach perfect justice ${ }^{87}$ seems flimsy modern support for the American Rule. While verdicts may be only approximations of ideal justice, it does not logically follow that their correctness will be increased by in effect adjusting them uniformly downward; nor that it is acceptable for valid legal rights not to be worth the expense of their vindication. As Dean Pound has suggested, a law which measures compensation in purely monetary terms must almost by definition operate imperfectly as to matters not easily measured in dollars. ${ }^{88}$ In matters which lend themselves to precise monetary measurement, however, the law can approach and should strive toward the nearly perfect result. Since attorney's fees are for the most part easily measurable, there is no basis in reason for the law to abandon all attempts at full compensation in regard to this aspect of damages.

\section{Likelihood of Penalizing Innocents}

The notion that no one should be penalized simply for defending or prosecuting an action ${ }^{89}$ is superficially attractive but not in itself a compelling defense of the American Rule. The burden of paying a fee award would, after all, be borne only by the losing litigant. We are committed to the conclusion that the courtroom loser is more often a wrongdoer than an innocent, and that it would be unworkable or prohibitively expensive to fix responsibility more carefully case by case. ${ }^{90}$ One commentator -suggesting that a judge is "as like as not to do injustice when

85 Goodhart, supra note 6 , at 877 .

${ }^{86}$ See, e.g., Gordon v. Hartford Sterling Co., 350 Pa. 277, 38 A.2d 229 (1944); Barndollar v. Groszkiewicz, 178 Pa. Super. 110, 113 A.2d. 154 (1955). See also text accompanying notes 48,74 supra.

87 See note 53 supra.

88 R. Pound, Social Control. Through Law 59 (1942).

${ }^{89}$ See text accompanying note 45 supra.

${ }^{90}$ See Ehrenzweig, supra note 4, at 797. 
he seeks to do justice,"91 would apparently deny the courts' ability to arrive at a correct result in a given case, and thus find justice to require that fees be borne by each litigant as in the past. This essentially pessimistic assertion, however, was wellanswered by Professor Goodhart, who suggested that if justice were indeed so much a matter of luck it might be advisable to dispense with courts and lawyers altogether, since it would be "cheaper, and certainly less dilatory, to spin a coin."92

\section{Effect on Litigation}

The argument that the American Rule is necessary to encourage individuals to vindicate their legal rights ${ }^{93}$ is not so easily dispensed with, for it directly contradicts one major argument for abandoning the Rule. Although it has been said that the "need to provide the individual with private law enforcing power" makes rejection of the American Rule a "practical necessity," ${ }^{44}$ studies suggest that the English Rule does not invariably encourage the disadvantaged to pursue their rights. ${ }^{95}$

\section{a. The Small Claimant}

Rejection of the American Rule clearly should have the effect of encouraging the person with a just but monetarily small claim to seek redress. Current practice tends to deter the prosecution of even clearly meritorious small claims by litigants who could at best recover less than the often high expenses of counsel; the contingent fee, moreover, fails to promote such claims, for even a fifty percent fee is unlikely to interest an attorney if the claim is truly a small one. And what is true for plaintiffs also holds for defendants: the cost of defending against an unjust small claim may easily exceed the cost of simply paying what is demanded. This result is distasteful, for it ranks legal rights by dollar values, ignoring rights of unquestioned importance simply because they are monetarily small ${ }^{96}$ or incapable of precise measurement. ${ }^{97}$ Were attorneys assured of recompense for their time and service, emphasis would be placed on the

91 Satterthwaite, Increasing Costs to be Paid by the Losing Party, 46 N.J.L.J. 133 (1923).

${ }^{92}$ Goodhart, supra note 6, at 877. See also Ehrenzweig, supra note 4, at 796 .

${ }^{93} \mathrm{See}$ text accompanying note 45 supra; see also Kuenzel, supra note 6 , at 82 (citing a statement by the Judicial Council of California on the need to promote litigation).

${ }^{94}$ Note, supra note 59 , at 328 .

95 See generally Final Report of the Commission on Supreme Court Practice \& Procedure, July, 1953, Cmd. 8878, at 236, 246, 337 [hereinafter cited as Evershed REPORT].

${ }^{96}$ Cf. Christensen, Aids in Meeting Legal Expenses, 37 Ford. L. REv. 383 (1969).

97 Injunctive relief in civil rights litigation may be as vital as its monetary value is incalculable. See Note, Allowance of Attorney's Fees in Civil Rights Litigation, 7 CoLUm. J.L. \& Soc. Prob. 381 (1971). 
merits of these small claims, which would almost inevitably be promoted.

It must be remembered, however, that not all small claims are clearly meritorious, and the impact of an English Rule of attorney's fees might well be to discourage litigation of these claims. ${ }^{98}$ Similarly, the fear of a penalty upon loss of a small claim may induce premature or unjust settlement where the claimant is poor and the claim is less than open-and-shut. ${ }^{99}$

Moreover, flooding the courts with even meritorious small claims is not a goal for which there is broad support. Although in frontier America it may have been national policy to encourage individuals to submit disputes to the judicial process, ${ }^{100}$ current public policy favors settlement of disputes outside the courtroom. ${ }^{101}$ One of the greatest contemporary legal problems, in fact, is that of monumental court congestion, ${ }^{102}$ a congestion often manipulated to force unjust settlements or to exact the so-called nuisance value of frivolous claims. ${ }^{103}$

Given the growing availability of small claims courts ${ }^{104}$ it may be not only acceptable but the course of wisdom to continue a rule which in most cases deters small claimants from the ordinary courts.

\section{b. The Poor Litigant}

It is generally less than clear what effect adoption of a system of assessing attorney's fees against losing litigants ("universal indemnity") would have upon the poor litigant. As it is, the American Rule hardly seems to encourage him to vindicate his legal rights. ${ }^{105}$ Rejection of the American Rule would likely encourage assertion of clear legal rights with a high probability of success but would add to the deterrence of the present system in cases where the litigant's claim was novel or of arguable worth. ${ }^{106}$ Since a poor man is likely to fear the prospect of

${ }^{98}$ See Mause, supra note 6 , at 33-34.

${ }^{99}$ Id. 31 n.23, 33-34. Cf. Letter from Melvin D. Close, Jr., member of the Nevada bar, to the University of Pennsylvania Law Review, Aug. 24, 1973, on file in Biddle Law Library, University of Pennsylvania (noting divergence of opinion among Nevada legislators on the effects upon litigation which would result from a system indemnifying the winning litigant).

${ }_{100}$ R. POund, supra note 88.

${ }^{101}$ See Note, Use Of Taxable Costs To Regulate The Conduct Of Litigants, 53 Colum. L. REv. 78, 86-92 (1953) \& sources cited. See also Kuenzel, supra note 6.

${ }^{102}$ See ABA Spectal Committee on Court Congestion, Ten Cures for Court Congestion (1959).

${ }_{103}$ Kuenzel, supra note 6 , at 78 .

104 For a recent study of the operations of one such court, see Steadman \& Rosenstein, "Small Claims" Consumer Plaintiffs In the Philadelphia Municipal Court: An Empirical Study, 121 U. Pa. L. REv. 1309 (1973). at 238 .

${ }^{105}$ See note 94 supra \& accompanying text. But see Evershed RePORT, supra note 95,

${ }^{106}$ See Mause, supra note 6, at 31-33, 36. 
paying both counsel more than a wealthy one, ${ }^{107}$ it would seem likely that-except where completely judgment-proof-he would often be manipulated into premature settlement.

It cannot be said confidently that the disadvantaged litigant's rights are often well enough defined, either as to fact or law, that the risk of such deterrence is acceptable. On the other hand, in many cases in which the poor litigant's rights are clear, legal representation is currently available thanks to the indigenously American "contingent fee arrangement."108 Though illegal as champertous at common law and in England today, ${ }^{109}$ and though tightly controlled and much maligned even in America, ${ }^{110}$ the contingent fee arrangement has been "summed up in one phrase, '[t]he poor man's fee' "111 and felt to give the poor man the keys to the courthouse door.

\section{A Modest Proposal}

A system of universal indemnity would, it appears, discourage not only the small claimant and the poor litigant, but also the bringing of suits or the imposition of defenses in new or complex and largely unpredictable areas of law. In an essentially common law country like ours, such a system would frustrate the vitality and continued development of the law.

On balance, then, a system properly responding to the evils of the present should focus squarely upon the elimination of wrongful conduct, and seek to discourage abuse of existing legal apparatus. This goal can best be achieved by judicial or legislative expansion of the existing bad faith exception to the Ameri-

${ }^{107}$ Id. 36.

${ }^{108}$ For an exhaustive analysis of the role of the contingent fee in American jurisprudence, see F. Mackinnon, Contingent Fees for Legal Services (1964).

${ }^{109}$ Id. 38. The Solicitor's Act of 1957,5 \& 6 Eliz. 2, c. 27, provides that:

Nothing in [the Act] "shall give validity to-(a) any purchase by a solicitor of the interest, or any part of the interest, of his client in any action, suit or other contentious proceeding; or (b) any agreement by which a solicitor retained or employed to prosecute any action, suit or other contentious proceeding stipulates for payment only in the event of success ...."

${ }_{110}$ The contingent fee is, in fact, illegal in one state. F. MacKinnon, supra note 108, at $39-41$.

Major objections to such fee arrangements have been ethical ones. "The temptation to make improper bargains," id. 160, has been specifically cited as one danger of the contingent fee; likewise, the often exorbitant size of such fee recoveries has been pointed to with an accusatory finger. Id. 160-67.

Some critics have noted the inherent conflcits of a system in which an attorney has simultaneously a vested financial interest in the size and speed of the recovery, and near complete control over the settlement of a suit, $i d$. 196-98, and over potentially dilatory trial tactics. Id. 200. Others have suggested that the contingent fee system may have greatly contributed to the enormous court backlogs that exist today. Id. 201-02. Finally, some have pointed to the ugly incentive to ambulance chasing, $i d$. 203, heightened by potentially enormous contingent awards. 15 (1972).

${ }^{111}$ Id. 160. See also Note, Contingent Fee, Champerty or Champion?, 21 Crev. ST. L. Rev. 
can Rule. ${ }^{12}$ Current practice, awarding fees only against the most flagrant and obstinate violators of the law, fails to discourage wholly unfounded and entirely vexatious actions and defenses, which even a system favoring litigation over settlement would abhor. It seems clear that, as the Massachusetts Judicial Council has suggested, "[t]he possibility of having to pay the lawyer's bills of both parties to the action makes a plaintiff think twice before he sues out a writ and a defendant think twice before he defends an action which ought not to be defended."113

If litigants were made to know that all unnecessary delays cost money-money that will be charged to their account should they be shown to have litigated in bad faith-it can be confidently predicted that dilatory tactics would lose favor, and that respect for our legal apparatus would grow. ${ }^{114}$ Furthermore, it seems not unlikely that litigation techniques would tend to become streamlined, as each side in a contested action would be encouraged, contrary to present practice, to minimize the opposition's expenses. While our judicial system must seek to encourage the just claim and the just defense, it need not do so with maximum inefficiency. The wise employment of a system of penalties upon unreasonable conduct is likely to open wider the narrow gates of the law ${ }^{115}$ by deterring frivolous litigation and spurring just settlement.

Although it is difficult to draw a bright line between reasonable and unreasonable courtroom conduct, there are sufficient guidelines for legislatures to design a workable plan which can be refined by the courts. In essence, it would seem that, as Professor Mause suggests, the "key element" in determining a litigant's reasonableness would be the "predictability of the outcome"116 of litigation undertaken or defenses interposed. In

\footnotetext{
${ }^{112}$ See notes 48-58 supra \& accompanying text.

${ }^{113}$ First Report of the Judicial Council of Massachusetts, 11 Mass. L.Q. 1, 63 (1925).

114 Former Chief Justice Warren explained:

Today, because the legal remedies of many of our people can be realized only after they have sallowed with the passage of time, they are mere forms of justice.

And, to the extent that this is so, there is created a disrespect for the law. ...
} aba Special. Commission on Court Congestion: Ten Cures for Court Congestion 7 (1959). note 9 .

${ }^{115}$ See R. Pound, supra note 88, at 58; Note, supra note 101. See also Cheatham, supra

Cf. F. Kafka, Before the Law, in The Penal Colony 148 (1948). The position of the disadvantaged litigant bears striking resemblance to Kafka's "man from the country" who "prays for admittance to the Law." Though in time made aware of "a radiance that streams inextinguishably from the gateway of the Law," fear, ignorance and intimidation result in his coming to know only "the fleas in ... [the] fur collar" of the gatekeeper, and in his reaching his end without ever having been admitted through a gateway reserved only for him. Id. 148-50.

${ }^{116}$ Mause, supra note 6, at 29. Professor Mause also analyzes an indemnity plan structured upon the relative reasonableness of the loser's position; Mause examines English, Swedish and German systems in considerable detail. Id. 46-50. 
designing legislation to codify such a principle, new attention to a model statute proposed by Professor Stoebuck-premised upon a broad conception of bad faith-would be desirable. ${ }^{117}$

\section{Fear of Abuse}

One fear frequently voiced in defense of the status quo is that a contrary rule would lend itself to rampant abuse. ${ }^{118}$ While it is indisputably true that some counsel demand more and some clients pay more, ${ }^{119}$ a system which awards fees clearly need not unquestioningly reimburse all actual out-of-pocket costs. Just as the English system has developed a rule whereby-regardless of the outlays by a litigant for counsel-only costs determined to have been necessary and proper for the successful completion of litigation are allowed, ${ }^{120}$ the American system can presumably interpose sufficient review of fee awards to allay fears that attorneys would indulge in profiteering. ${ }^{121}$

The fear of protracted litigation over the reasonableness of attorney's fees ${ }^{122}$ seems similarly unfounded. While some litigation certainly may ensue, the fact that the losing party in such litigation must bear its costs will act as a deterrent to excessively prolonged controversy. Litigating the adequacy of an award of attorney's fees is, after all, inherently self-defeating for at least one party. Should the system of fee calculations proposed in this Comment ${ }^{123}$ give rise to abuse, moreover, the English mechanism ${ }^{124}$ or an even simpler system of fee schedules ${ }^{125}$ could be adopted to minimize litigation over fees. At any rate, the benefit resulting from a system of reasonable awards would outweigh the cost of the technical problems which would attend its adoption.

\section{F. Conclusion}

The reasons which may once have justified the "historical accident" which is the American Rule for private litigation no

117 Stoebuck, supra note 6, at 211. Professor Stoebuck would favor a system which routinely awards fee except when an action turns upon a question of law not previously decided. When the prevailing party is adjudged to have prosecuted or defended an action in bad faith, obstinately refused to settle, or otherwise abused the legal apparatus, he would allow a judge to diminish or eliminate the award to that party.

${ }^{118}$ See text accompanying notes 37-39 supra.

$119 \mathrm{Id}$.

${ }^{120}$ See note 7 supra.

121 For a discussion of the difficulties of determining a "reasonable" fee award, see Section IV, infra.

${ }^{122}$ See text accompanying notes $37-38$ supra.

${ }^{123}$ See notes $387-423$ infra \& accompanying text.

124 See note 7 supra.

125 Stoebuck, supra note 6, at 211-18. See also Geller, Unreasonable Refusal To Settle and Calendar Congestion - Suggested Remedy, Committee RePorts of Comparative Law Division, Proceedings abA International and Comparative Law Section 134 (1962). 
longer carry persuasive weight. The present American Rule has no compelling justifications; it breeds abuse and harbors rank inequity. A contrary rule broadening the scope of the currently narrow bad faith exception would foster out of court settlement, relieve court congestion, discourage expensive and dilatory courtroom tactics, discourage nuisance suits and meritless defenses, and encourage the pursuit of claims which are small but clearly just. Since needed change is not likely to come from the courts, which have proved themselves for over two centuries to be predisposed to perpetuate "a lingering remnant of the old barbaric dispensation," sacrificing "philosophy, justice and common sense ... to formal and senseless precedents," 126 it would appear that legislative action has become necessary.

\section{Public Interest Litigation and the Private AtTorney GENERAL}

\section{A. Introduction}

The recent increase in public interest litigation has brought to the attention of the legal community as never before the problem of equal access to the judicial system. ${ }^{127}$ Implicit in the concept of due process, equality before the courts and under the law is a value basic to our Constitution, ${ }^{128}$ and equal access to the courts is a prerequisite to achieving this goal. It is therefore surprising to find that only in recent years has there been

${ }^{126}$ Watson, A Rationale of The Law Of Costs, 16 CENT. L.J. 306, 307 (1883).

${ }^{127}$ With startling suddenness the legal profession has recently come to realize that a society can guarantee equal justice only by providing all citizens with effective access to the institutions by which justice is obtained and that for millions of Americans the unavailability of lawyers' services has made justice inaccessible.

Note, Neighborhood Law Offices: The New Wave in Legal Services for the Poor, 80 Harv. L. REv. 805 (1967).

The democratic promise of "Equal Justice Under Law" necessarily requires equal access to legal institutions. In this Nation, perhaps more than in any other, access to legal institutions presupposes access to lawyers.

Hearings on Attorney's Fees Before the Subcomm. on Representation of Citizen Interests of the Senate Comm. on the Judiciary, 93d Cong., 1st Sess. at 798 (Oct. 4, 1973) (Testimony of J. Kline, Esq., of Public Advocates, Inc.) [hereinafter cited as Hearings].

See generally Boddie v. Connecticut, 401 U.S. 371 (1971); ABA Section on Individual. Rights \& Responsibilities, The Private Law Firm and Pro Bono Public Programs: A Responsive Merger (1971); Cahn \& Cahn, Power to the People or the Profession? - The Public Interest in Public Interest Law, 79 Y ALE L.J. 1005 (1970); Halpern \& Cunningham, Reflections on the New Public Interest Law: Theory and Practice at the Center for Law and Social Policy, 59 GEo. L. Rev. 1095 (1971).

${ }^{128}$ Equality before the courts is a necessary condition for impartial adjudication, a central element in the achievement of "fairness" in due process.

[A] just and correct result-which is precisely what the adversary system is designed to produce-is least likely when there is a marked difference in the quality of legal representation available to respective adversaries or in the financial resources that the respective adversaries can devote to the presentation of their side of the case.

Hearings, supra note 127, at 841 (Testimony of D. Flannery, Esq.). 
widespread recognition of the economic barriers to gaining access to the courts for the plaintiff of moderate or limited means, seeking to vindicate or challenge public policy goals. ${ }^{129}$ Foremost among the issues raised by this circumstance is the propriety of court awarded attorney's fees.

Although traditional equitable exceptions to the American Rule against the award of counsel fees ${ }^{\mathbf{1 3 0}}$ to the successful plaintiff are well established, ${ }^{131}$ pressure for more liberal fee shifting has been mounting since the 1968 Supreme Court decision in Newman v. Piggie Park Enterprises, Inc. ${ }^{132}$ a suit challenging racial discrimination in a chain of restaurants. The Court there adopted a new theory for awarding fees under Title II (public accommodations) of the Civil Rights Act of $1964 .{ }^{133}$ The statute provided for an award of fees within the discretion of the court, ${ }^{134}$ but the Supreme Court used reasoning that was to prove more far-reaching.

When a plaintiff brings an action under [Title II], he cannot recover damages. If he obtains an injunction, he does so not for himself alone but also as a "private attorney general," vindicating a policy that Congress considered of the highest priority. If successful plaintiffs were routinely forced to bear their own attorneys' fees, few aggrieved parties would be in a position to advance the public interest by invoking the injunctive powers of the federal courts. Congress therefore enacted the provsion for counsel fees-not simply to penalize litigants who deliberately advance arguments they know to be untenable but, more broadly, to en-

${ }^{129}$ See, e.g., Boddie v. Connecticut, 401 U.S. 371, 375 (1971) ("[T]his court has seldom been asked to view access to the courts as an element of due process.").

It is important to note that the impact of fee awards in public interest litigation is by no means limited to the poor. As J. Kline testified at the Senate Hearings:

But it is not simply the poor who are without legal assistance in public interest cases, and this is a fact not widely recognized. ... [O]ne of the central features that distinguishes public interest litigation from other suits is that the final judgment will affect not only the parties, but a broad segment of the public at large. Furthermore, such litigation normally seeks only injunctive and declaratory relief, not damages. Therefore, rarely will an individual-even a wealthy individual-be likely to seek out and pay counsel to commence costly litigation to vindicate, not his own private rights, but widely shared public rights. In other words, any single individual's interest in the enforcement of broad public rights is normally diffused in the public interest. In these circumstances it is not rational for any person to attempt to capture his or her minute portion of the aggregate good by using personal funds to pay the full cost of enforcing the mutual right.

Hearings, supra note 127, at 801 (footnote omitted). text.

${ }^{130}$ For an extended discussion of the Rule, see notes $1-47$ supra \& accompanying

${ }^{131}$ See notes 157-63 infra \& accompanying text.

132390 U.S. 400 (1968) (per curiam).

${ }^{133} 42$ U.S.C. $\$ \$ 2000$ a to $2000 \mathrm{a}-6$ (1970).

${ }^{134} \mathrm{Id}$. $\S 2000 \mathrm{a}-3(\mathrm{~b})$ (quoted in note 21 infra). 
courage individuals injured by racial discrimination to seek judicial relief under Title II.

It follows that one who succeeds in obtaining an injunction under that Title should ordinarily recover an attorney's fee unless special circumstances would render such an award unjust. ${ }^{135}$

The lower federal courts have applied this relatively new rationale for awarding attorney's fees to an increasingly broad range of cases, including lawsuits in which no statutory provision for award of counsel fees existed, ${ }^{136}$ the plaintiff was not obligated to pay counsel, ${ }^{137}$ where the suit was for damages, ${ }^{138}$ or the award was to a successful defendant. ${ }^{139}$ Some courts have even awarded fees to an unsuccessful plaintiff. ${ }^{140}$ At the present time, then, the private attorney general rationale for awarding fees is rapidly gaining acceptance in the federal courts. In fact, since the decision in Piggie Park, few federal appellate decisions have reversed lower court rulings awarding fees based on the private attorney general theory, and some have reversed, or remanded for further consideration, the failure of a lower court to award fees. ${ }^{141}$ The Supreme Court has granted certiorari in one such case, Bradley $v$. School Board, ${ }^{142}$ which is apparently the only recent decision reversing a lower court award of fees.

Because it provides a means of helping to equalize access to the courts for groups seeking to litigate issues of importance to the public, the private attorney general theory of fee shifting seems especially attractive. However, there are conceptual difficulties that threaten the continued vitality of this new theory. ${ }^{143}$ Before discussing these problems, it will be helpful to review the background and development of the theory.

135390 U.S. at 402 (footnotes omitted).

${ }^{136}$ See Lee v. Southern Home Sites Corp., 444 F.2d 143 (5th Cir. 1971) (action for racial discrimination in the sale of real estate brought under 42 U.S.C. $\$ 1982$ (1970)).

${ }^{137}$ See La Raza Unida v. Volpe, 57 F.R.D. 94 (N.D. Cal. 1972) (plaintiffs represented by foundation-funded public interest law firm and by government-funded Legal Services attorneys).

${ }^{138}$ See Lyle v. Teresi, 327 F. Supp. 683 (D. Minn. 1971) (damages awarded in action against police alleging a conspiracy to deprive plaintiff of his civil rights).

${ }_{139}$ See United States v. Gray, 319 F. Supp. 871 (D.R.I. 1970) (successful defendant was subjected to a meritless prosecution brought by the United States under the public accommodations section (Title II) of the Civil Rights Act of 1964).

${ }_{140}$ See McEnteggart v. Cataldo, 451 F.2d 1109 (1st Cir. 1971) (fees assessed against defendants who prevailed on appeal, where plaintiff was forced to go to court to obtain statement of reasons to which he was constitutionally entitled); Sierra Club v. Lynn, 364 F. Supp. 834 (W.D. Tex. 1973) (fee award to unsuccessful plaintiffs in environmental action because legal action spurred improvements in environmental related aspects of design for real estate development).

${ }_{141}$ See Cooper v. Allen, 467 F.2d 836 (5th Cir. 1972); Jinks v. Mays, 464 F.2d 1223 (5th Cir. 1972); Ojeda v. Hackney, 452 F.2d 947 (5th Cir. 1972); McEnteggart v. Cataldo, 451 F.2d 1109 (1st Cir. 1971); Lee v. Southern Home Sites Corp., 444 F.2d 143 (5th Cir. 1971).

142472 F.2d 318 (4th Cir. 1972), cert. granted, 412 U.S. 937 (1973).

${ }^{143}$ See notes 210-25 infra \& accompanying text. 


\section{B. Background of Fee Award Theories}

\section{Factors Influencing Their Development}

Judge Jerome Frank first coined the phrase "private attorney general" in a 1943 case involving a private citizen's standing to sue a public official for violation of a specific statutory duty. ${ }^{144}$ But the theory was not used to support the shifting of fees until several other factors had appeared.

First, fee shifting in commercial litigation under federal regulatory statutes - such as antitrust actions ${ }^{145}$ _provided a successful example of the use of congressionally-authorized awards as an incentive for private enforcement of public policy. Second, the central role of litigation in the civil rights movement, beginning with Brown $v$. Board of Education, ${ }^{146}$ led to congressional enactment of attorney's fee provisions in the various civil rights acts of the 1960's. ${ }^{147}$ Such provisions probably reflect the legisla-

${ }^{144}$ See Associated Indus., Inc. v. Ickes, 134 F.2d 694, 704 (2d Cir.), vacated as moot, 320 U.S. 707 (1943). The court reasoned:

Instead of designating the Attorney General, or some other public officer, to bring such proceedings [to prevent another official from acting in violation of his statutory powers], Congress can constitutionally enact a statute conferring on any non-official person, or on a designated group of non-official persons, authority to bring a suit to prevent action by an officer in violation of his statutory powers; ... there is nothing constitutionally prohibiting Congress from empowering any person, official or not, to institute a proceeding involving such a controversy, even if the sole purpose is to vindicate the public interest. Such persons, so authorized, are, so to speak, private Attorney Generals.

${ }_{145}$ See, e.g., Clayton Act, 15 U.S.C. $\& 15$ (1970). This is perhaps the best known statute authorizing the award of fees to the successful plaintiff. The statute provides for a mandatory award.

Any person who shall be injured in his business or property by reason of anything forbidden in the antitrust laws may sue therefor in any district court of the United States in the district in which the defendant resides or is found or has an agent, without respect to the amount in controversy, and shall recover threefold the damages by him sustained, and the cost of suit, including a reasonable attorney's fee.

For other examples of statutory provisions for award of counsel fees in commercial litigation, see notes 60-73 supra \& accompanying text.

146347 U.S. 483 (1954).

147 For example, Title II of the Civil Rights Act of 1964 provides:

In any action commenced pursuant to this subchapter, the court, in its discretion, may allow the prevailing party, other than the United States, a reasonable attorney's fee as part of the costs, and the United States shall be liable for costs the same as a private person.

42 U.S.C. \& $2000 \mathrm{a}-3(\mathrm{~b})(1970)$.

The Fair Housing Act of 1968 takes a slightly different approach:

The court may grant as relief [for violations of a right secured by the Act], as it deems appropriate, any permanent or temporary injunction, temporary restraining order, or other order, and may award to the plaintiff actual damages and not more than $\$ 1,000$ punitive damages, together with court costs and reasonable attorney fees in the case of a prevailing plaintiff; Provided, That the said plaintiff in the opinion of the court is not financially able to assume said attorney's fees.

Id. \& 3612(c).

It can be argued that the original text of 42 U.S.C. $\$ 1983(1970)$ also provided for the award of attorney's fees. Section 1983 was part of the Civil Rights Act of 1871 and is derived from the Act of Apr. 20, 1871, ch. 22, 17 Stat. 13. The original uncodified ch. 22 provided that plaintiffs suing under that provision be granted the same remedies as were 
tive perception that the rights involved were necessarily to be dependent on private enforcement and that, where the economic disparities between parties were likely to be great, the creation of federally protected rights would be meaningless without fee shifting. ${ }^{148} \mathrm{~A}$ third factor was the liberalization and expansion by the courts of the rules of standing. ${ }^{149}$ The result has been to permit greater access to the judicial system for those who would represent the public interest or challenge the legality of government action. Access has also been improved by a fourth factor, the liberalization of the rules governing class actions. ${ }^{150}$ These rules have changed to facilitate access to the courts for those whose claims would be uneconomical to litigate individually. Finally, the growing number of lawyers seeking to represent previously unrepresented groups in "public interest" litigation has provided additional impetus for fee shifting under the private attorney general rationale. Legal Aid, the OEO Legal Services Program, private pro bono programs, and "public interest" law firms have all served to greatly increase the amount of "public" litigation before the courts and thus to increase the pressure for fee shifting.

available under other federal civil rights acts. One such remedy was the award of attorney's fees. Thus, as there is no indication that the change was made for substantive reasons, the original language should still be followed and fees whould be awarded under $\S 1983$ as originally intended by Congress. See Brief for Plaintiff in support of petition for counsel fees, Armstead v. Starkville Mun. Separate Sch. Dist., No. EC70-5 IS (N.D. Miss., brief filed Dec. 21, 1973).

${ }_{148}$ The Senate Committee on Labor and Public Welfare Report, on what was ultimately to become Title VII of the Emergency School Aid Act through the Education Amendments of 1972, offers the following explanation:

[School desegregation] laws are not not being enforced throughout the nation.

The Federal government is devoting neither the time, effort nor the financial resources necessary for adequate law enforcement. ... The Committee believes that funds should be made available to assure that Federal laws will be enforced throughout the country, while at the same time, under the policies and programs set forth in this bill, voluntary efforts to achieve quality education in stable integrated environments are assisted throughout the nation.

Although litigation directed toward the enforcement of these laws is often time consuming and therefore expensive, litigation on behalf of those injured by breach of legal requirements remains the most effective and economical method of which the Committee is aware to obtain protection of legal rights.

S. REP. No. 92-61, 92d Cong., Ist Sess. 25 (1971).

${ }^{149}$ See Barlow v. Collins, 397 U.S. 159 (1970) (tenant farmers challenging regulation of Secretary of Agriculture); Flast v. Cohen, 392 U.S. 83 (1968) (federal taxpayers challenging expenditure of federal funds); Office of Communications of the United Church of Christ v. FCC, 359 F.2d 994 (D.C. Cir. 1966) (representatives of listening public challenging license renewal for radio station); Bebchick v. Public Util. Comm'n, 318 F.2d 187, (D.C. Cir.), cert. denied, 373 U.S. 913 (1963) (transit riders challenging fare increase); Powelton Civic Home Owners Ass'n v. HUD, 284 F. Supp. 809 (E.D. Pa. 1968) (residents of affected area challenging urban renewal program). But see Sierra Club v. Morton, 405 U.S. 727 (1972) (environmental group seeking to restrain Interior Dep't from approving an extensive skiing development in a national park).

150 See FED. R. CIv. P. 23; Notes of Advisory Committee on 1966 Amendment to Rules, 39 F.R.D. 69, 98-107 (1966). But see Zahn v. International Paper Co., 39 F.R.D. 69, 98-107 (1966). 94 S. Ct. 505 (1973) (holding that each member of the plaintiff class in a diversity action must meet the $\$ 10,000$ jurisdictional requirement of 28 U.S.C. $\$ 1332$ (a) (1970) in order for the suit to be maintained as a class action). 
Together, these factors dramatized the economic barriers impeding the meaningful access of the average citizen to judicial relief, particularly where the defendant was likely to be either a large corporation or the state, the issues involved were likely to be novel and complex, and the relief sought was likely to be injunctive rather than monetary. Because of the gross disparity in financial resources between typical plaintiffs and defendants, federal rights were not likely to be enforced in the private sphere. ${ }^{151}$ Congress responded to this perception by providing for award of attorney's fees in legislation creating private rights of action where such a disparity in legal resources seemed most likely to exist (e.g., Truth-in-Lending actions), ${ }^{152}$ giving courts a basis for development of the private attorney general theory.

\section{Evolution of Traditional Equitable Grounds}

The historical factors and evidences of congressional sentiment, discussed above, have also prompted liberalization of the two traditional equitable exceptions to the general American Rule. ${ }^{153}$ As part of its general equity powers, ${ }^{154}$ the federal judiciary has always been able to award attorney's fees in a proper case. One major exception allows courts to award counsel fees to a litigant whose opponent has pursued a clearly unfounded action or defense and has done so "in bad faith, vexatiously, wantonly or for oppressive reasons." 155 The obvious purpose of such an award is to protect the honest litigant and to discourage abuse of the courts. ${ }^{156}$

The bad faith exception has been expanded most notably in the recent line of school desegregation cases, beginning with Bell

${ }_{151}$ In 1964, Senator Humphrey stated that the estimated cost of a civil rights suit which was appealed was $\$ 15,000$ to $\$ 18,000$. See 110 CoNG. Rec. 6541 (1964). In view of the recent inflation, these costs must have increased substantially in the past 10 years.

${ }_{152}$ See Truth-in-Lending Act, 15 U.S.C. \& 1640 (1970); Clean Air Act Amendments of 1970, 42 U.S.C. \$ 1857h-2(d) (1970); Emergency School Aid Act, 20 U.S.C. $\$ 1617$ (Supp. II, 1972); Federal Water Pollution Control Act Amendments of 1972, 33 U.S.C. $\S$ 1365(d) (Supp. II, 1972).

${ }_{153}$ Although the general American Rule against award of counsel fees as costs is often cited, arrangements have developed to soften the harsh consequences of this rule where the litigants are likely to be of unequal economic strength. Contingent fee arrangements, coupled with awards for pain and suffering in tort cases, for example, are a means of overcoming the hardship imposed by the American rule. See notes 108-11 supra \& accompanying text.

${ }_{154}$ See, e.g., Sprague v. Ticonic Nat'l Bank, 307 U.S. 161, 164 (1939) (“Allowance of such [attorney's] costs in appropriate situations is part of the historic equity jurisdiction of the federal courts.") (Frankfurter, J.); notes 48-54 supra \& accompanying text. omitted).

${ }^{155} 6$ J. Moore, Federal Practice If 54.77[2], at 1709 (2d ed. 1971) (footnote

${ }_{156}$ Hall v. Cole, 412 U.S. 1, 5 (1973) ("In this class of cases, the underlying rationale for 'fee shifting' is, of course, punitive .....") (dictum).

For a discussion of the possible use of an expanded version of this rationale to alleviate some of the problems created by the American Rule, see notes 113-26 supra \& accompanying text. 
v. School Board ${ }^{157}$ in 1963 . By reformulating the traditional bad faith standard, the courts in those cases have moved to close the economic gap between black plaintiffs and governmental defendants where the plaintiffs seek only to move local schools in the direction clearly required by public policy. Thus in Cato $v$. Parham, ${ }^{158}$ the court awarded fees despite no finding of bad faith on the part of the school board. Noting that "whatever progress has been made in the direction of desegregation ... has followed judicial prodding,"159 the court found the need for judicial intervention to be a sufficient substitute for more traditional bad faith. The new elements for an award based on "bad faith" thus seem to be a clearly defined and established right, and the need for judicial assistance in securing that right. Shifting fees in such a situation recognizes the unfairness of imposing the costs of litigation on the party who should have freely enjoyed his rights. ${ }^{160}$

Congress, perhaps reacting to the strictness of even this standard, has enacted a still more liberal standard in section 718 of the Emergency School Aid Act. ${ }^{161}$ The section allows an award of fees when the court finds that the "proceedings were necessary to bring about compliance."162 This seems to be a simple "but for" test under which fees would usually be awarded so long as the plaintiffs litigated in good faith. In fact, the Supreme Court has ruled that fee awards should be the normal rule under this statute. ${ }^{163}$

The second major area where the federal courts exercise

157321 F.2d 494 (4th Cir. 1963). The appellate court reversed the district court's denial of attorney's fees, citing the school board's

long continued pattern of evasion and obstruction which included not only the defendants' unyielding refusal to take any initiative, thus casting a heavy burden on the children and their parents, but their interposing a variety of administrative obstacles to thwart the valid wishes of the plaintiff for a desegregated education.

Id. at 500 .

${ }_{158} 293$ F. Supp. 1375 (E.D. Ark.), affd, 403 F.2d 12 (8th Cir. 1968).

${ }^{159} I d$. at 1378 .

${ }^{160}$ The bad faith exception is incorporated into various state and federal procedural rules. For example:

In an action or part of an action, if the court finds that any proceeding was had (1) in bad faith, (2) without substantial justification, or (3) for purposes of delay, the court shall require the moving party to pay to the adverse party the amount of the costs thereof and the reasonable expenses incurred by the adverse party in opposing such proceeding, including reasonable attorneys fees.

MD. CT. APP. (CIv.) R. 604(b).

The Federal Rules of Civil Procedure make more limited provision for fee awards in instances of bad-faith litigation. See, e.g., FED. R. Crv. P. 37(a), (c).

16120 U.S.C. § 1617 (Supp. II, 1972).

162 Id.

${ }^{163}$ See Northcross v. Board of Educ., 412 U.S. 427, 428 (1973) ("[T] plaintiff 'should ordinarily recover an attorney's fee unless special circumstances would render such an award unjust." ").

Northcross is likely to lead to a distinct line of school desegregation cases focusing on the size of the fee award, rather than on the propriety of any award. 
their equitable power to award attorney's fees is that involving a common fund. The award is made to avoid the unjust enrichment of a class at the expense of the individual litigant, who has created or protected a fund in which all share. ${ }^{164}$ The fee is normally awarded to the individual litigant out of the common fund. Here, the doctrine has been elaborated into the so-called "substantial benefit" rule. One commentator has explained the development:

The traditional common fund over which the court exercises its jurisdiction always represents a benefit capable of translation into money. Conceptually, however, the fund is the aggregate benefit produced by the litigation, and the court taxes any convenient resource jointly owned by the true beneficiaries. Since the court's power to award legal fees is totally independent of the existence of a fund, it is not difficult to understand the judicial development from the monetary common fund theory to the nonmonetary substantial benefit variant. To award fees under the substantial benefit rule, the court must have jurisdiction over some resource which is not at issue in the litigation but which is common to all the beneficiaries. ${ }^{165}$

The Supreme Court endorsed this development in the 1970 case of Mills v. Electric Auto-Lite Co., ${ }^{166}$ a shareholders' derivative action brought under section 14(a) of the Securities Exchange Act of $1934^{167}$ to dissolve a corporate merger approved by the shareholders on the basis of a misleading proxy statement. The Court held that "fair and informed corporate suffrage" was a benefit produced by the suit sufficient to justify the award of fees out of corporate assets where the court had jurisdiction over the assets and the benefit extended to all of the shareholders. Benefit here has nothing to do with the subjective evaluation of the corporation or a majority of its shareholders. Instead it is defined in terms of achieving the purposes of the statute under

${ }^{164}$ The most frequently cited statement of the traditional common fund rationale is found in Trustees v. Greenough, 105 U.S. 527, 532 (1882):

[I]f the complainant is not a trustee, he has at least acted the part of a trustee in relation to the common interest .... It would not only be unjust to him, but it would give to the other parties entitled to participate in the benefits of the fund an unfair advantage. He has worked for them as well as for himself; and if he cannot be reimbursed out of the fund itself, they ought to contribute their due proportion of the expenses which he has fairly incurred. To make them a charge upon the fund is the most equitable way of securing such contribution.

165 Note, Awarding Attorney and Expert Witness Fees in Environmental Litigation, 58 Cornell L. Rev. 1222, 1234 (1973) (footnote omitted).

${ }^{166} 396$ U.S. 375 (1970).

16715 U.S.C. $\$ 78 \mathrm{n}(\mathrm{a})(1970)$. 
which suit is brought for the common benefit. Justice Harlan used broad language in justifying this new standard:

[T] he stress placed by Congress on the importance of fair and informed corporate suffrage leads to the conclusion that, in vindicating the statutory policy, petitioners have rendered a substantial service to the corporation and its shareholders. ... [P]rivate stockholders' actions of this sort "involve corporate therapeu- tics," and furnish a benefit to all shareholders by providing an important means of enforcement of the proxy statute. ${ }^{168}$

The Mills Court expressed the benefit rule in terms not limited to any particular class of litigation. Fees would be allowed in all cases "where a plaintiff has successfully maintained a suit, usually on behalf of a class, that benefits a group of others in the same manner as himself." 169 Furthermore, fees may be shifted "where the litigation has conferred a substantial benefit on the members of an ascertainable class, and where the court's jurisdiction over the subject matter of the suit makes possible an award that will operate to spread the costs proportionately among them." 170

This "substantial benefit" fee award was developed most clearly in the lower federal courts prior to Mills in cases involving political rights of union members. Beginning in 1951 with Rolax v. Atlantic Coast Line Railroad Co., ${ }^{171}$ federal courts have awarded fees to union members successfully suing their unions to enforce rights of due process, fair representation and free speech or fiduciary duties owed to minority members. ${ }^{172}$ The cases reflect

168396 U.S. at 396 (citations and footnotes omitted).

The Court's use of the term "corporate therapeutics" is taken from Hornstein, Legal Therapeutics: The "Salvage" Factor in Counsel Fee Awards, 69 HaRv. L. REv. 658 (1956). See also Hornstein, The Counsel Fee in Stockholder's Derivative Suits, 39 Colum. L. REv. 784 (1939).

Such reasoning led one commentator to read the decision as establishing a law-enforcement-as-benefit rationale, legitimatizing the fee award "based solely on law enforcement policy considerations." Note, supra note 59, at 327. See also Note, Attorneys' Fees in Shareholder Derivative Suits: The Substantial Benefit Rule Reexamined, 60 CAL. L. REv. 164 (1972); Note, Shareholder Suits: Pecuniary Benefit Unnecessary for Counsel Fee Award, 13 Stan. L. Rev. 146 (1960); Note, Attorneys' Fees: What Constitutes a "Benefit" Sufficient to Award Fees From Third Party Beneficiaries, 1972 WASH. U.L.Q. 271.

169396 U.S. at 392.

${ }^{170}$ Id. at $393-94$.

171186 F.2d 473 (4th Cir. 1951).

${ }^{172}$ See, e.g., Gartner v. Soloner, 384 F.2d 348, 354-55 (3d Cir. 1967):

Plainly the federal courts are empowered ... to come to the aid of any union member whose civil rights have been infringed upon by the union and to compensate that member for reasonable counsel fees and other expenses resulting from that ... action.

... In the context of the Labor Management Act it is untenable to assert that in establishing the bill of rights under the Act Congress intended to have 
the courts' common perception - of three persuasive factors for awarding fees: the fiduciary relationship between a labor union and its members; ${ }^{173}$ the disparity in economic resources between the individual plaintiff and the defendant union; ${ }^{174}$ and the importance of the political rights vindicated to the maintenance of democratic fairness. ${ }^{175}$ As in Mills, the "benefit" is actually the vindication of congressional policy.

In Hall $v$. Cole ${ }^{176}$ the Supreme Court reaffirmed the benefit approach used in Mills. The suit was brought by a union member claiming that his right to free speech had been infringed by the union. Justice Brennan's opinion explained the benefit conferred:

$[T]$ here can be no doubt that, by vindicating his own right of free speech guaranteed by $\S 101(a)(2)$ of Title 1 of the LMRDA, respondent necessarily rendered a substantial service to his union as an institution and to all of its members. When a union member is disciplined for the exercise of any of the rights protected by Title I, the rights of all members of the union are threatened. And,

those rights diminished by the unescapable [sic] fact that an aggrieved union member would be unable to finance litigation and would have no hope of remuneration even if he could some way or other proceed with his suit.

See also Blankenship v. Boyle, 337 F. Supp. 296 (D.D.C. 1972) (breach of fiduciary duty); Burch v. International Ass'n of Machinists, 78 L.R.R.M. 2444 (S.D. Fla. 1971) (denial of due process); Local 648, Retail Clerks v. Retail Clerks Int'l Ass'n, 299 F. Supp. 1012 (D.D.C. 1969) (insurgent candidates dismissed for political opposition); Sands v. Abelli, 290 F. Supp. 677 (S.D.N.Y. 1968) (plaintiff blacklisted and removed from office by local union).

${ }^{173}$ Congress in section 501(a) [of the Labor-Management Reporting and Disclosure Act, 29 U.S.C. § 501(a) (1970)] has defined the fiduciary status of union officers. They are to execute their trust for the benefit of the organization and its members. Should such officers violate their trust, a member of the union is authorized under section 501(b) to initiate steps looking toward remedial action. Thus, any such member and his counsel are to be protected, all to the end that the membership itself may police its own labor organization, whether the suit seeks damages or an accounting "or other appropriate relief for the benefit of the labor organization."

Bakery Workers Int'l Union v. Ratner, 335 F.2d 691, 696 (D.C. Cir. 1964).

${ }_{174} \mathrm{It}$ is difficult for individual members of labor unions to stand up and fight those who are in charge. The latter have the treasury of the union at their command and the paid union counsel at their beck and call while the member is on his own. . . . An individual union member could not carry such a heavy financial burden. Without counsel fees the grant of federal jurisdiction is but a gesture for few union members could avail themselves of it.

Cole v. Hall, 462 F.2d 777, 780-81 (2d Cir. 1972), quoted with approval in Hall v. Cole, 412 U.S. 1,13 (1973).

${ }_{175}$ Congress recognized that it was imperative that all union members be guaranteed at least "minimum standards of democratic process and conduct for the administration of internal union affairs." 105 CoNG. REc. 6471 (1959) (Remarks of Sen. McClellan concerning Title I of the Labor-Management Reporting and Disclosure Act, 29 U.S.C. $\S \S$ 411-15 (1970)). Plaintiffs right of free speech and assembly and other "political" rights are guaranteed by Title I of the LMRDA and were deemed "vital to the independence of the membership and the effective and fair operation of the union as the representative of its membership." Cole v. Hall, 462 F.2d 777, 780 (2d Cir. 1972), quoted in Hall v. Cole, 412 U.S. 1, 8 (1973).

176412 U.S. 1 (1973). 
by vindicating his own right, the successful litigant dispels the "chill" cast upon the rights of others. ... Thus, as in Mills, reimbursement of respondent's attorneys' fees out of the union treasury simply shifts the costs of litigation to "the class that has benefitted from them and that would have had to pay for them had it brought the suit."177

Additionally, fee shifting was thought to be a means of giving vitality to the protection of statutory rights. ${ }^{178}$

The reasoning of Mills and Hall has also been used to allow fee awards in cases involving free speech within colleges ${ }^{179}$ and the denial of membership in a stock exchange. ${ }^{180}$ The extension of the substantial benefit theory to cases involving nonmonetary political rights may be reducing the basis of that theory to the simple encouragement of private law enforcement, at least where political processes and democratic fairness are in issue. Perhaps the courts are actually reshaping their traditional fee shifting powers to lower the economic barriers to access to the judicial system by the citizen-unionmember-shareholder, and to help balance, at least in the area of political rights and due process, the representation of these important interests.

It is not surprising that the courts would want to accomplish such an objective. The factors discussed above ${ }^{181}$ which have brought previously unrepresented interests before the courts have also introduced an unprecedented number of public policy issues into the courts. ${ }^{182}$ Confronted with demands that they play a more active role in determing issues with wide public impact, the courts perhaps perceived that a balanced representation of affected interests would be essential to sound decision, and that balanced representation was in many areas of public policy severely distorted by the disparity in financial and legal resources available to different sectors of the public in such litigation. ${ }^{183}$ Seen in this perspective, the change was necessary to preserve

${ }^{177}$ Id. at 8-9 (citations omitted).

${ }^{178}$ Id. at 13 .

${ }^{179}$ See Rainey v. Jackson State College, 481 F.2d 347 (5th Cir. 1973); Stolberg v. Members of the Bd. of Trustees, 474 F.2d 485 (2d Gir. 1973).

${ }^{180}$ See Bright v. Philadelphia-Baltimore-Washington Stock Exch., 327 F. Supp. 495

(E.D. Pa. 1971).

${ }^{181}$ See notes 145-150 supra \& accompanying text.

182 See, e.g., Ojeda v. Hackney, 452 F.2d 947 (5th Cir. 1972) (court required to determine the rights of welfare recipients); Wyatt v. Stickney, 344 F. Supp. 387 (M.D. Ala. 1972) (court called upon to consider the proper level of treatment for mentally ill patients).

${ }_{183}$ Having represented both corporations and public interest groups, I believe it is fair to conclude that as things now stand, the more complex the public issue, the more likely it is that the decision-maker-be it an administrative agency or a court-will be presented with an increasingly one-sided approach to the problem.

Hearings, supra note 127, at 841 (Testimony of D. Flannery, Esq.). 
the fairness of policy making by the third branch of government, and was parallel and complementary to the development of the private attorney general theory.

\section{Development of the Private Attorney General Theory}

Given this background, the adoption of a new and more comprehensive theory for award of counsel fees by the Supreme Court is hardly surprising. Newman v. Piggie Park Enterprises, Inc. ${ }^{184}$ was perhaps the strongest case possible for acceptance of the private attorney general theory. There was express statutory provision for fee shifting, the action was for injunctive relief, the protection of civil rights was an especially appropriate function for the Court, the litigation would benefit a broader segment of the public than those bringing the suit, and there was no means within the Court's jurisdiction of distributing the cost of the litigation among the benefited class in accordance with the substantial benefit approach.

Although a strict interpretation of Piggie Park would limit the holding to require these factors, the lower federal courts have lost little time in using variations on the basic approach to justify fee shifting in a rapidly expanding line of private attorney general cases. Throughout, the common factor has been the necessity of fee shifting to permit meaningful private enforcement of prurected rights. ${ }^{185}$ An early case which applied the private attorney general theory to litigation in the absence of express statutory authority was Lee v. Southern Home Sites Corp. ${ }^{186}$ The court there looked to the statutory provision for fee shifting in the Fair Housing Law $^{187}$ as evidence of congressional policy in closely related legislation. Finding that " $[t]$ he statute . . . depends entirely on private enforcement," 188 the court applied the Piggie Park reasoning to the suit before it. ${ }^{189}$

This holding was soon followed by other decisions which

184390 U.S. 400 (1968); see text accompanying note 132 supra.

${ }^{185} \mathrm{~A}$ characteristic of many of the cases in each of these lines of authority [cases following substantial benefit or private attorney theory] is that the plaintiff represented a minority group or interest and only by resort to the courts could the plaintiff ensure that the defendants fulfilled their fiduciary or other obligations to persons in the plaintiff's situation. Particularly where the defendant is a governmental entity, such litigation may be regarded as a means of offsetting the possibly limited opportunities for minority interests to assure through the political process that their governing bodies fulfill their duties to them, as part of their obligations to the general community. The availability of an attorney fee award in such a case would presumably have the desirable effect of minimizing some barriers to this exercise of constitutional rights.

Brief for United States as Amicus Curiae at 10 n.6, Bradley v. School Bd., 412 U.S. 937 (1973), granting cert. to 472 F.2d 318 (4th Cir. 1972) (citations omitted).

186444 F.2d 143 (5th Cir. 1971).

${ }_{187}$ See 42 U.S.C. \& 3612 (c) (1970).

188444 F.2d at 147.

${ }^{189}$ Suit was brought under 42 U.S.C. $\$ 1982$ (1970). 
extended the private attorney general theory to cases arising under related statutes. ${ }^{190}$ Many of these decisions extending the application of the private attorney general theory also found bad faith on the part of the defendant, ${ }^{191}$ so the new theory was applied in cases where the award was justified on more traditional grounds. However, numerous other awards have since been made under the same sections without any finding of bad faith. ${ }^{192}$

The private attorney general theory has only recently been applied to areas other than civil rights where no statutory authorization for fee shifting exists. Sims $v$. Amos ${ }^{193}$ is a leading decision applying the new approach to reapportionment litigation. There the court awarded fees for the following reasons:

In instituting the case sub judice, plaintiffs have served in the capacity of "private attorneys general" seeking to enforce the rights of the class they represent. ... If, pursuant to this action, plaintiffs have benefited their class and have effectuated a strong congressional policy, they are entitled to attorneys' fees regardless of defendants' good or bad faith. . . . Indeed, under such circumstances, the award loses much of its discretionary character and becomes a part of the effective remedy a court should fashion to encourage public-minded suits, . . a and to carry out congressional policy. ${ }^{194}$

The two elements identified in this decision-benefit to the public and effectuation of a strong congressional policy-suggest an overlap with the substantial benefit approach. Indeed, in many reapportionment decisions awarding fees, it is difficult to discern which approach is the basis for the award. ${ }^{195}$ The distinction between the two approaches has been obscured by the more liberal extensions of the substantial benefit theory. ${ }^{196}$ In concept,

${ }^{190}$ See Cooper v. Allen, 467 F.2d 836 (5th Cir. 1972) (\$ 1981); NAACP v. Allen, 340 F. Supp. 703 (M.D. Ala. 1972) (\$ 1983); Lyle v. Teresi, 327 F. Supp. 683 (D. Minn. 1971) (same).

${ }^{191}$ See, e.g., Lee v. Southern Home Sites Corp., 444 F.2d 143 (5th Cir. 1971); NAACP v. Allen, 340 F. Supp. 703 (M.D. Ala. 1972); Sims v. Amos, 340 F. Supp. 691 (M.D. Ala.), affd, 409 U.S. 942 (1972).

${ }^{192}$ See, e.g., Jinks v. Mays, 350 F. Supp. 1037 (N.D. Ga. 1972) (\$ 1983); Brown v. Ballas, 331 F. Supp. 1033 (N.D. Tex. 1971) (\$ 1982).

For an excellent collection of reported and unreported decisions involving awards of attorney's fees, see M. Derfner, Attorneys' Fees in Pro Bono Publico Cases (Aug. 1972) (available from the Lawyers' Committee for Civil Rights, Washington, D.C.).

193340 F. Supp. 691 (M.D. Ala.), affd, 409 U.S. 942 (1972).

194 Id. at 694 (citations omitted).

195 See, e.g., Clark v. DeSoto Parish Police Jury, Civil No. 17,266 (W.D. La. 1972) (reapportionment).

${ }^{196}$ While Mills v. Electric Auto-Lite Co., 396 U.S. 375 (1970), expanded the benefit theory to include nonmonetary benefits, it did not define what now are the limits of the term "benefit." If benefit can be defined as simply a result of law enforcement, then the benefit and the private attorney general theories become indistinguishable so long as the 
the benefit theory is defensive, preventing unjust enrichment by taxing the true beneficiaries of the litigation, while the private attorney general theory is offensive, promoting the effective implementation of public policy by taxing the defendant. ${ }^{197}$ Since the defendant often, as in reapportionment and much corporate and labor litigation, is also the representative of the beneficiaries, the two approaches coalesce in result. So long as the court has within its jurisdiction the means of distributing the costs of the litigation, the benefit theory is adequate. The private attorney general theory becomes necessary only when the court cannot feasibly match the costs with the benefits which are created or protected by judicial action.

The two most recent leading cases extending the private attorney general theory of court awarded attorney's fees were authored by Judge Peckham of the Northern District of California. La Raza Unida v. Volpe $e^{198}$ is the first application of this theory to environmental litigation, ${ }^{199}$ representing a significant extension of the approach. Stanford Daily $v$. Zurcher, ${ }^{200}$ decided less than a year later, awarded fees to a party (not suspected of a crime) who brought an action for injunctive relief under section $1983^{201}$ after being subjected to a search which violated the fourth amendment. Of course the award of fees under section 1983 is not new, but the opinion tries to establish new criteria for such an award which are worth examining in detail and in comparison to the standards used in La Raza.

The cases share some important characteristics. Both suits were for injunctive relief; the relevant statutes were silent as to fee awards and lacked "a 'meticulously detailed' pattern of remedies"; ${ }^{202}$ the defendants in each were, in effect, governmen-

court has control over a solvent party, such as a corporation, labor union or governmental body, roughly representing the class that can be said to have been benefited. See generally Note, Attorneys' Fees: What Constitutes a "Benefit" Sufficient to Award Fees From Third Party Beneficiaries, 1972 WASH. U.L.Q. 271.

${ }^{197}$ See La Raza Unida v. Volpe, 57 F.R.D. 94, 98 (N.D. Cal. 1972).

${ }^{198} \mathrm{Id}$.

For recent comment on the impact and importance of the La Raza opinion, see Nussbaum, Attorney's Fees in Public Interest Litigation, 48 N.Y.U.L. Rev. 301 (1973); Note, Awarding Attomey and Expert Witness Fees in Environmental Litigation, 58 CoRNELL L. REv. 1222 (1973); Note, Awarding Attorneys' Fees to the "Private Attorney General": Judicial Green Light to Private Litigation in the Public Interest, 24 HAST. L.J. 733 (1973) [hereinafter cited as Green Light]. The relationship of attorney's fees to public interest litigation is discussed in testimony given in hearings held by Senator Tunney before the Subcommittee on Representation of Citizen Interests of the Senate Committee on the Judiciary on Oct. 4 \& 5, 1973. See Hearings, supra note 127, at 787-88 (Opening Remarks of Sen. Tunney on Court Award of Attorney's Fees).

${ }^{199}$ Although the case can be read as a housing decision with as much justification, it seems that it will more often be cited for its breakthrough in the environmental area, if only because that is currently a more litigated area of the law.

200366 F. Supp. 18 (N.D. Cal. 1973).

20142 U.S.C. \& 1983 (1970).

${ }^{202}$ The award of attorney's fees has been held inappropriate where the governing statute provides for detailed and complete remedies without authorizing award of counsel fees. See Fleischmann Distilling Corp. v. Maier Brewing Co., 386 U.S. 714 (1967). 
tal units; and the plaintiffs in each case would have been unable to finance such litigation were it not for exceptional legal assistance from unpaid attorneys. In other words, plaintiffs in both cases would normally have been unable to seek judicial protection absent the possibility of fee shifting.

The La Raza opinion identified three factors which governed the decision to award fees under the private attorney general theory: "the strength of the Congressional policy, the number of people benefited by the litigants' efforts, and the necessity and financial burden of private enforcement." ${ }^{203}$ Stanford Daily, on the other hand, gave four criteria:

Where as here fee shifting is necessary to insure the vindication of important constitutional rights and appropriate because of the inadequate remedies otherwise available, because it is consistent with a remedy increasingly furnished by Congress, and because of the high social value placed upon the rights involved, an award of attorney's fees as costs is essential, lest these important rights be relegated to a mere platitude. ${ }^{204}$

The opinion does not explain the difference between "important constitutional rights" and "high social value placed on the rights involved." These seem to be essentially the same as the "strength of Congressional policy" criterion in La Raza, and it appears they all derive from decisions such as Mills and Hall $v$. Cole which stressed the societal importance of the rights vindicated.

The other common factor is the necessity of private enforcement, which comprehends both the inadequacy of public enforcement ${ }^{205}$ and the need for fee shifting to make private enforcement possible. ${ }^{206}$ The concern here is that without an award of fees, the rights protected by the law will not be capable of adequate implementation or vindication.

The La Raza criterion with regard to the number of people benefited seems to be aimed at limiting the scope of the exception by distinguishing public from private litigation. Although the court could have pointed to the deterrent effect of litigation

${ }^{203} 57$ F.R.D. at 99.

${ }^{204}$ Stanford Daily v. Zurcher, $366 \mathrm{~F}$. Supp. 18, 24 (footnote omitted).

205 "The only public entities that might have brought suit in this case were named as defendants in this action and vigorously opposed plaintiff' contentions. Only a private party could have been expected to bring this litigation. . . 57 F.R.D. at 101 .

${ }^{206}$ In many 'public interest' cases only injunctive relief is sought, and the average attorney or litigant must hesitate, if not shudder, at the thought of 'taking on' an entity such as the California Department of Highways, with no prospect of financial compensation for the efforts and expenses rendered. The expense of litigation in such a case poses a formidable, if not insurmountable, Id. obstacle. 
which protects the rights of all citizens, this factor is absent from the Stanford Daily opinion wherein only a few people were affected directly.

Finally, the Stanford Daily criterion, "consisten[cy] with a remedy increasingly furnished by Congress," seems merely to recognize the parallel remedies developing in Congress and in the courts. ${ }^{207}$ No such factor is mentioned in La Raza, although the court there could have cited amendments to environmental legislation enacted contemporaneously with the decision. ${ }^{208}$ The two decisions, read together, thus summarize the major relevant factors considered by the courts in the decision to award fees under the private attorney general theory. ${ }^{209}$

\section{Analysis of the Theory}

\section{When Is Its Application Appropriate?}

Several conceptual difficulties with the four factors identified in La Raza and Stanford Daily emerge on close analysis. After discussing the problems associated with each, this section will propose a new set of criteria for fee awards. In this discussion two underlying goals are assumed: the fair allocation of the inevitable costs of litigation, and the strengthening of legal protections through increased access to judicial remedies. ${ }^{210}$

The obvious difficulty with the "strength of public policy" factor common to the decisions is that it requires a subjective evaluation on the part of a judge. In effect, it asks him to distinguish important rights from less important ones and thereby invites usurpation of the legislative function. As the Fourth Circuit opinion in Bradley $v$. School Board ${ }^{211}$ noted:

[I]t will launch courts upon the difficult and complex task of determining what is public policy, an issue normally reserved for legislative determination, and, even more difficult, which public policy warrants the encouragement of award of fees to attorneys for private litigants who voluntarily take upon themselves the character of private attorneys-general. ${ }^{212}$

${ }^{207}$ E.g., the statutory provisions for award of attorney's fees discussed in notes 147 , 152 suepra.

${ }_{208}$ See, e.g., note 152 supra.

${ }^{209}$ Although Stanford Daily does not explicitly state that the fee award is based on the private attorney general theory, the elements in the court's analysis as well as the dependence on La Raza make it apparent that this was the ground of the decision.

${ }_{210}$ Increased access does not necessarily imply more litigation with the resultant problems of clogged court calenders and long delays. Access is important as a bargaining chip in settlement negotiations, and equal ability to threaten trial tends to equalize the bargaining relationship.

${ }_{211} 472$ F.2d 318 (4th Cir. 1972), cert. granted, 412 U.S. 937 (1973).

${ }^{212}$ Id. at 329 (footnote omitted). 
It is by no means clear why the courts are the appropriate locus for such decisions. It is appropriate for the courts to use their equitable powers where necessary to make statutory protections effective, ${ }^{213}$ because the rights have been enacted by the legislature. But to establish a criterion that seeks to promote such enacted rights but not others seems a legislative function. The difficulty is thus not only that no reasonably objective standards can be formulated to differentiate statutes on the basis of the relative strength of their respective policy goals, but more fundamentally that such differentiation is not the proper function of the judiciary. Where rights are created by the legislature the courts may imply the existence of remedies necessary to their effective protection. ${ }^{214}$ They stand on less sure footing when they themselves attempt to arrange the priorities for public policy enforcement.

"Necessity of private enforcement," the second major factor discussed above, looks to the adequacy of public enforcement and seeks economic equalization of representation in cases where private enforcement is necessary. Where suit is brought against governmental agencies and officials, the necessity of private enforcement is obvious. In such situations private citizens alone must "guard the guardians" and the disparity in legal resources is likely to be greatest. ${ }^{215}$

On the other hand, where the action is brought against a private defendant, public enforcement may be adequate. Assuming no bad faith, why should a losing private defendant have to pay more when suit is brought by a private plaintiff than when a public official seeks enforcement? If public enforcement is inadequate due to lack of staff or of funding, then it may well be appropriate for the court to authorize awards to private litigants who are in essence doing the job of public enforcement for the government. Since public enforcement is normally supported from general tax revenues, however, why should the losing defendant be taxed exclusively? Fairness would seem to require that the private attorney general be awarded fees from the same

"213 Thus, in suits for damages based on violations of federal statutes lacking any express authorization of a damage remedy, this Court has authorized such relief where, in its view, damages are necessary to effectuate the congressional policy underpinning the substantive provisions of the statute. J.I. Case v. Borak, 377 U.S. 426 (1964); Tunstall v. Brotherhood of Locomotive Firemen \& Engineermen, 323 U.S. 210,213 (1944).

Bivens v. Six Unknown Named Agents, 403 U.S. 388, 402 (1971) (Harlan, J., concurring).

214 While various rationales have been given for including attorney's fees as costs, the courts are in essence making a judgment that including attorney's fees as costs is an additional remedy necessary to effectuate the congressional underpinnings of a substantial program.

Stanford Daily v. Zurcher, 366 F. Supp. 18, 23.

${ }^{215}$ See note 206 supra. 
source as the public law enforcement budget, i.e., the public treasury. ${ }^{216}$ Taxing the defendant instead of the public treasury does act as a deterrent by raising the cost of an unsucessful defense in court, but it is not at all clear that this is fair or desirable from a public policy point of view. If the effect is primarily to deter litigation (or encourage nuisance suits) instead of to deter the undesirable conduct, public policy is poorly served by taking the case out of the judicial system. Thus, the deterrence argument alone should not prevent the award of fees from public funds.

As to the issue of disparity in legal resources, one underlying policy motivation is the courts' need to have balanced representation for the parties so that an informed decision may be reached. ${ }^{217}$ More importantly, in decisions concerning major issues of public policy, where it is crucial for the court to consider all sides before making a decision, fee awards for those parties that would not otherwise be able to afford representation serve the interests of the court. ${ }^{218}$ The difficulty here is that if awards are to be made as part of public policy making, what standards are to govern the determination of which interests are eligible for such awards and which are not? If, on the other hand, fee awards are made only to those who would otherwise be unable to protect their rights adequately in court, does consideration of the economic position of the plaintiff deprive the taxed defendant of the equal protection of the laws?219

The third criterion, "number of people benefited," is an attempt to distinguish public suits from private ones. But as Stanford Daily and other suits indicate, courts have awarded fees where only a single individual or a small group was directly benefited. Using terms like "deterrence" or "therapeutics" to show an indirect benefit to more people simply confuses the conceptual differences between the private attorney general theory and the substantial benefit theory. ${ }^{220}$ The private attorney general theory speaks, in essence, to the effective implementa-

216 See Mause, supra note 6.

217 This is particularly true where the factual and legal issues are complex or technical. See, e.g., Sierra Club v. Lynn, 364 F. Supp. 834 (W.D. Tex. 1973) (environmental); Hargrove v. Caddo Parish School Bd., Civil No. 17,630 (W.D. La. 1972) (reapportionment); Martinolich v. Dean, Civil No. 3111 (S.D. Miss. 1972) (reapportionment).

${ }^{218}$ See note 183 supra.

219 Why should the private defendant bear a greater potential liability toward a poorer or less well organized plaintiff than toward one who is able to finance litigation on his own? This seems to create something of a double standard, particularly where the attorney's fee award exceeds the other monetary relief. $C f$. Advance Business Systems \& Supply Co. v. SCM Corp., 287 F. Supp. 143 (D. Md. 1968), affd E remanded for modification on other grounds, 415 F.2d 55 (4th Cir. 1969), cert. denied, 397 U.S. 920 (1970) $(\$ 35,875$ fee award in antitrust action in which actual damages were $\$ 16,714)$. The private defendant is not in the same position in this regard as is the government, for it is the government's unique obligation to provide for equality of law enforcement.

220 See note 197 supra \& accompanying text. 
tion of public policy, regardless of the number of people benefited. The substantial benefit theory of Mills, on the other hand, is addressed to the fair matching of the costs and benefits of the litigation, regardless of public policy concerning the rights created or protected. "Deterrence" or "therapeutics" language seems to be a signal that the benefit theory is being transformed into a means of encouraging policy enforcement. While awards for such enforcement may be appropriate, particularly where political processes are involved, ${ }^{21}$ the theory used should be correctly identified as that of the private attorney general. Otherwise the courts and legislatures that use the theories will be more vulnerable to criticism and doubts, and awards will be made less often than they should be because of the usual conservative response to confusion. ${ }^{222}$ In addition, as recognized by Judge Peckham in La Raza, ${ }^{223}$ many public interest suits do not benefit all of the public evenly. Suits against governmental bodies rarely fit the benefit model on any but the most generalized basis.

Thus, especially in suits against public entities, the size of the class benefited is not a determinative factor in deciding whether to award fees under the private attorney general theory. The problem of identifying suits involving the public interest remains, however, and it will be discussed in the following section.

The fourth factor mentioned by Judge Peckham, "consisten[cy] with a remedy furnished by Congress," seems unneeded in light of the courts' traditional equitable powers to fashion effective remedies. But to the extent that legislative provisions for the award of fees exist in closely related statutes, the policy behind a fee award is given increased weight and the complaint about judicial usurpation of legislative decisions expressed above ${ }^{224}$ is partially answered. Perhaps this criterion could be more meaningfully understood to imply that where there is parallel legislative authority, fee awards will be made as a matter of course unless special circumstances would make the

221 See note 175 supra \& accompanying text.

${ }^{222}$ Cf. Bradley v. School Bd., 472 F.2d 318 (4th Cir. 1972), cert. granted, 412 U.S. 937

(1973); notes 239-45 infra \& accompanying text.

${ }_{223}$ Mills extended the scope of the common-fund justification for the awarding of fees by holding that no pecuniary benefit need be demonstrated. ... In so doing it has become exceedingly difficult to trace the benefits of litigation to their ultimate beneficiaries, so as to apportion the attorneys' fees amongst them. Because of the attendant difficulties in determining the ultimate beneficiaries, the "common fund" mold simply does not fit the present situation. As Judge Merhige stated in Bradley v. School Board .... , wherein he rejected the common fund theory as a basis for awarding attorneys' fees in a school desegregation case: 'School desegregation cases, or any suits against governmental bodies, do not fit this fund model without considerable cutting and trimming.'

57 F.R.D. at 97 (citations and footnotes omitted). ${ }^{224}$ See notes 211-14 supra \& accompanying text. 
award unjust. Thus the legislative authorization of discretionary fee shifting can be understood as transferring the burden of proving special circumstances to the losing party. ${ }^{225}$

\section{Proposed Criteria for Fee Shifting}

If the private attorney general theory is best understood as a means of encouraging public policy enforcement through the courts, then clearly the most fundamental problem faced by those who would use it is to limit its application to litigation brought in the public interest. Given the present American Rule, courts will be unwilling to adopt a rationale that could lead to a universal fee award system. ${ }^{226}$ The task, then, is to formulate workable criteria for determining what litigation serves the public interest in a way appropriate for the award of counsel fees.

The term "public interest," although frequently used here and elsewhere, raises serious conceptual difficulties. ${ }^{227}$ In a pluralistic society such as ours, it is difficult to maintain that there is a single public interest or that any particular policy is a priori in the public interest. Substantive approaches to a definition easily reduce to differences in subjective values. ${ }^{228}$

A procedural approach, however, emphasizing fairness and the importance of representation for every interest in the policy making process, may be more fruitful. This approach is an integral part of American idealism. ${ }^{229}$ As one writer observed: "The method for obtaining a full or equalized presentation of competing sides in a conflict, whether they be people or ideas, is the central problem for our legal institutions. It is the central

225 Since the courts have always had the power to award fees in exceptional circumstances, statutory fee shifting provisions might be redundant on any other interpretation. See Northcross v. Board of Educ., 412 U.S. 427 (1973); Newman v. Piggie Park Enterprises, Inc., 390 U.S. 400 (1968).

${ }^{226}$ See Bradley v. School Bd., 472 F.2d 318 (4th Cir. 1972), cert. granted, 412 U.S. 937 (1973) (court strictly limited the private attorney general theory because, inter alia, of fears of the growth of the theory).

${ }^{227}$ See generally The Public INTERest (C. Friedrich ed. 1962) (NOMOS V); G. Schubert, The Public InTerest (1961); Riley, The Challenge of the New Lawyers: Public Interest and Private Clients, 38 GEo. WASH. L. REv. 547 (1970); Symposium-The Practice of Law in the Public Interest, 13 ARIz. L. Rev. 797 (1971); Comment, Public Participation in Federal Administrative Proceedings, 120 U. PA. L. REv. 702, 731 (1972); Note, The New Public Interest Lawyers, 79 YALE L.J. 1069, 1070 n.3 (1970).

${ }^{228}$ [C]ritical investigation has failed to reveal a statement of public interest theory that offers much promise as a guide either to public officials who are supposed to make decisions in the public interest or to research scholars who might wish to investigate the extent to which governmental decisions are empirically made in the public interest.

Schubert, Is There a Public Interest?, in The Public InTERest 172 (C. Friedrich ed. 1962) (NOMOS V).

${ }^{229}$ In a different context, Judge Learned Hand remarked: "[R]ight conclusions are more likely to be gathered out of a multitude of tongues than through any kind of authoritative selection. To many, this is, and always will be, folly; but we have staked upon it our all." United States v. Associated Press, 52 F. Supp. 362,372 (S.D.N.Y. 1943). 
focus of a 'public interest response." "230 Thus public interest representation can be defined as "representation of an otherwise inadequately represented policy position . . . formulated to promote an interest which will be affected by the decision to be made."231 This approach is based on ethical relativism which requires that all relevant interests and perspectives be heard before a decision is made. Under this definition, attorney's fees should be granted any party who seeks to represent a relevant policy position which is not normally represented before the court.

This conception of public interest litigation would result in a radical revision of the private attorney general theory as it now exists. It would, in essence, lead to fee awards regardless of whether the party is successful on the merits, regardless of any benefit that might result apart from full and fair representation.

However, due to the sweeping scope of such a change, other criteria may be needed to prevent complete dislocation of our judicial system. The fear of frivolous litigation is often given as a justification for limiting awards to successful litigants ${ }^{232}$ and is probably a valid argument here except when a court finds that an unsuccessful suit has served to further public policy goals ${ }^{233}$ or educate the court. ${ }^{234}$ Although a successful defense against public prosecution may occasionally serve to "police the prosecution" and may also serve to represent a normally underrepresented interest before the court, ${ }^{235}$ no readily apparent policy of

${ }^{230}$ F. Marks, The Lawyer, The Public, and Professional Responsibility 51 (1972).

23: Comment, Public Participation in Federal Administrative Proceedings, 120 U. PA. L. REv. 702, 731 (1972) (emphasis in original).

The Comment notes further that there are two qualifications to this definition: the function of public interest representation may be served by others than those usually identified as "public interest groups"; and the concept of an "interest" is defined by the decisionmaker (the court) in each individual case.

${ }^{232}$ Typical of the expressed Congressional intent with respect to the award of attorney's fees under $\$ 2000 \mathrm{a}-3(\mathrm{~b})$ [allowing award of attorney's fees in actions brought under Title II of the Civil Rights Act of 1964 to only the prevailing party] is the following remark by Senator Lausche during debate prior to passage:

"That language was inserted in the bill to deter the bringing of lawsuits without foundation." 110 Cong. Rec. at 13189-90.

Senator Pastore agreed:

"The purpose of this provision $* * *$ is to discourage frivolous suits ***."110 Cong. Rec. at 13720-21.

United States v. Gray, 319 F. Supp. 871,872 (D.R.I. 1970) (footnote omitted).

${ }^{233}$ See Sierra Club v. Lynn, 364 F. Supp. 834, 847 (W.D. Tex. 1973) (court will consider fee award to unsuccessful plaintiffs in environmental action because legal action spurred improvements in environmental aspects of design for real estate development).

${ }^{234} S_{e e}$ Hargrove v. Caddo Parish School Bd., Civil No. 17,630 (W.D. La. 1972) (court awarded fees to unsuccessful plaintiffs-intervenors, citing their service in educating the court in the problems of reapportionment).

${ }^{235}$ See, e.g., United States v. McLeod, 385 F.2d 734 (5th Cir. 1967) (criminal defendants awarded attorney's fees where prosecution was for purpose of intimidation of prospective voters). 
enforcement is consistently furthered by an award of fees to a successful defendant. ${ }^{236}$ Thus fee awards could generally be limited to successful plaintiffs even under the proposed system.

The strength of a procedural approach to "public interest" fee awards is that it focuses on the problem of access to the courts for those interests which have not previously enjoyed it. This includes not only the interests of the poor, but, more fundamentally, the interests of the unorganized and dispersed elements of society, which are uneconomical to pursue on a traditional basis. ${ }^{237}$ By awarding attorney's fees to representatives of such groups, the courts would be continuing their special concern for the rights of those who are not adequately represented in the other branches of government. ${ }^{238}$

A comparison of the district court's opinion in Bradley $v$. School Board ${ }^{239}$ with the opinion of the Fourth Circuit in that case $^{\mathbf{2 4 0}}$ will illustrate the conflict between the procedural and substantive approaches. The district court awarded attorney's fees on two grounds: a liberalized bad faith theory, ${ }^{241}$ and in the alternative the private attorney general theory. ${ }^{242}$ On appeal, the Fourth Circuit reversed, rejecting, inter alia, the private attorney general theory as applied to the case. The essence of the circuit court's rejection of that theory was the recognition that without statutory provision or indication of legislative intent, judges would be exceeding their proper role in attempting to determine priorities in public policy: ${ }^{243}$

Should the courts, in those instances where Congress has failed to grant the right [to shift counsel fees],

${ }^{236}$ But see United States v. Gray, 319 F. Supp. 871 (D.R.I. 1970) (award of fees to defendant motel owner under Title II of the Civil Rights Act of 1964 for successfully defending meritless action); Gaster v. Coldiron, 297 A.2d 384 (Del. 1972) (statutory authorization of fees to plaintiffs and not defendants in mechanic's lien cases violated equal protection under the 14th amendment).

${ }^{237}$ See note 129 supra.

${ }^{238}$ Professor Bickel characterizes this widely-shared perception as the Supreme Court's function "of guarding the elemental integrity of a system in which all groups have access to political power (through exercise of the franchise) . . .." A. BICKEL, THE Supreme Court and the Idea of Progress 86 (1970).

${ }_{239} 53$ F.R.D. 28 (E.D. Va. 1971), rev'd, 472 F.2d 318 (4th Cir. 1972), cert. granted, 412 U.S. 937 (1973).

${ }^{240}$ Bradley v. School Bd., 472 F.2d 318 (4th Cir. 1972), cert. granted, 412 U.S. 937 (1973). For a more complete criticism of the appellate opinion, see Green Light, supra note 198 , at $761-69$.

24153 F.R.D. at 39.

${ }^{242} I d$. at 42.

${ }^{243}$ The decision held that a court may grant an attorney's fee in a suit to promote the public policy expressed in legislative action only if Congress has expressly permitted it. 472 F.2d at 330-31. But in Hall v. Cole, 412 U.S. 1 (1973), the Supreme Court held that attorney's fees could be awarded unless the relevant statutes meticulously detail the remedies available to the plaintiff and fail to provide for attorney's fees. Id. at 9-14. Hopefully, this discrepancy will be eliminated when the Supreme Court reviews the Bradley decision. 
review the legislative omission and sustain or correct the omission as the court's judgment on public policy suggests? This, it seems to us, would be an unwarranted exercise of judicial power. ${ }^{244}$

This reasoning recalls the difficulties with the "strength of public policy" criterion discussed earlier, and recognizes the inappropriateness in democratic theory of judges making subjective judgments as to the relative stength of policies underlying statutory rights.

The district court articulated another more valid understanding of the theory that the appellate judges did not apparently perceive, namely the procedural approach that has been advocated here. "[J]ustice demands that plaintiff's attorneys be equipped to inform the court of the consequences of available choices; this can only be done if the availability of funds for representation is not left to chance." 245 The concern of this language is not with weighing substantive policies, but with providing adequate legal representation so that the court will have a sound basis upon which to determine what the relevant public policy is. The conflict between the district court's opinion and that of the circuit court is thus, at least with respect to the proper approach to the private attorney general theory, a conflict between substantive and procedural understandings of the public interest.

This discussion has assumed that meaningful legal representation is an important form of political power, one that should be equally available to all. In such a context, the award of fees to a private attorney general is simply one way of allocating the costs of law enforcement and policymaking. From this perspective the "necessity of private enforcement" factor discussed above, ${ }^{246}$ as it concerns the adequacy of public enforcement, may be justified on the grounds of reducing redundancy between public and private attorneys general. To avoid unduly inhibiting protected rights, however, the courts should look to the adequacy of actual enforcement by the government and not simply to the adequacy of potential or authorized public enforcement. ${ }^{247}$ Where the suit

24442 F.2d at 330 .

24553 F.R.D. at 42.

${ }^{246}$ See notes 215-16 supra \& accompanying text.

${ }^{247}$ Cf., e.g., Brewer v. School Bd., 456 F.2d 943, 950 n.22 (4th Gir. 1972) (declining to apply the private attorney general theory because both the Department of Justice and HEW were empowered to enforce the statute); Office of Communication v. FCC, 359 F.2d 994, 1003-04 (D.C. Cir. 1966) ("The theory that the Commission can always effectively represent the listener interests in a renewal proceeding without the aid and participation of legitimate listener representatives fulfilling the role of private attorneys general is one of those assumptions we collectively try to work with so long as they are reasonably adequate. When it becomes clear, as it does to us now, that it is no longer a valid assumption which stands up under the realities of actual experience, neither we nor the Commission can continue to rely upon it."). 
is against a public defendant, normally this criterion will automatically be met.

Where the suit is against a private defendant, and is necessary due to the inadequacy of public law enforcement, then clearly the private plaintiff is doing the job that public tax funds are supposed to finance. In such cases, it seems only just that the court be able to award counsel fees from the state or federal public treasury ${ }^{248}$ depending upon which governmental entity failed in its law enforcement duty.

Of course this power does not presently exist. But statutory creation of such a power, coupled with a realistic appropriation, would serve several beneficial purposes. It would encourage broader participation by lawyers in public interest litigation. It would allow awards even to losing litigants when, in the judgment of the court, the litigation served to improve or implement public policy. Most importantly, the public at large would benefit from the more evenly balanced adversary representation before the courts (and perhaps also before administrative agencies), for policy decisions and conflict resolution affecting the public interest would likely become more informed and thus more enlightened.

Such an award would also serve to balance the one-sided subsidy now created by federal tax policy. Present federal income tax. law allows business corporations (the most likely private defendants in public interest litigation) to deduct the cost of business related litigation, including attorney's fees, from taxable income. ${ }^{249}$ Thus, in terms of public tax expenditures, the federal treasury already indirectly contributes almost fifty percent ${ }^{\mathbf{2 5 0}}$ of one side's expenses in public interest litigation, regardless of the merit or reasonableness of such expenses. ${ }^{251}$ Awarding fees to

\footnotetext{
${ }^{248}$ Much of the resistance to the private attorney general theory may be based upon the fear of unfairness in taxing private defendants for attorney's fees. See note 78 supra \& accompanying text.

${ }^{249}$ Cf. Commissioner v. Tellier, 383 U.S. 687 (1966) (securities dealer allowed to deduct legal fees-incurred in unsuccessful defense of a criminal prosecution for securities fraud-as a business expense under INT. REv. CODE of 1954, § 162(a)).

It must be noted, however, that private contributions to public interest law firms are also deductible in limited circumstances. See REv. Proc. 71-39, 1971-2 Cum. Bull. 575-76. The value of this deduction to the individual donor (and thus of the government's share of his contribution to the public interest law firm) would, of course, vary according to his marginal tax rate. See generally Goldsmith, The IRS Man Cometh: Public Interest Law Firms Meet the Tax Collector, 13 ARIz. L. REv. 857 (1971).

${ }^{250}$ The current corporate income tax rate is about $48 \%$. See INT. REv. CoDE of 1954,
} $\S 11$.

251 [P] ublic tax dollars are in a very real sense being used to support that [corporate] litigation. The corporation's litigation expenses, its attorney's fees, its court costs and all costs connected with the litigation are deductible from the corporation's income tax. And that is win or lose, frivolous or non-frivolous, meritorious or nonmeritorious.

Hearings, supra note 127, at 835 (Testimony of D. Flannery, Esq.). 
public interest litigants from public funds would at least serve to balance the scales in this area.

An even more serious problem in implementing an effective private attorney general theory arises when the litigation is against a state government or the federal government. ${ }^{252}$ Even if the suit is not barred by sovereign immunity, ${ }^{253}$ attorney's fees are explicitly excluded from the costs that the United States is authorized to pay in cases where no specific statutory provision controls. ${ }^{254}$ This prohibition runs directly contrary to the policy considerations behind the private attorney general fee award. It acts to inhibit the legal accountability of federal agencies to those whom they represent. It obstructs the proper matching of expenses with benefits, and it serves to perpetuate the enormous disparity in legal resources between governmental agencies and the public interest litigant, often to the detriment of a fair adversary hearing on the merits.

If the private attorney general theory is to become fully viable, this statutory provision must be eliminated. ${ }^{255}$ There is no

${ }^{252}$ Federal agencies are named as defendants in a suprisingly large number of [public interest] cases .... This is particularly true in environmental cases and in suits by low-income persons challenging the denial of rights conferred by statute, such as the rights to welfare benefits, relocation housing, etc. In these cases the difficulties normally present in public interest cases are exacerbated by the enormous legal resources of a defendant federal agency. Where such a federal agency has been found by the courts to have violated important legislative policies or constitutional mandates, no reason appears why it should not be liable for the fees incurred by the plaintiffs who bore the burden of vindicating the rights of the affected public.

Id. 804 (Testimony of J. Kline, Esq., of Public Advocates, Inc.).

${ }^{253}$ Although a full discussion of the doctrine of sovereign immunity and the 11th amendment is beyond the scope of this Comment, it is relevant to the question of fee awards when a governmental entity is a defendant. In the past courts have refused to assess fees against a state because of the 11th amendment and its application to state sovereign immunity. See, e.g., Sincock v. Obara, 320 F. Supp. 1098 (D. Del. 1970). But a recent decision in the 5th Circuit, Gates v. Collier, No. 73-1790 (5th Cir., Dec. 5, 1973), held that such doctrines did not bar an award of attorney's fees against the State of Mississippi. The court based its result in large part upon the Supreme Court's affirmance without opinion of an award of attorney's fees against various officials of the State of Alabama. See Sims v. Amos, 340 F. Supp. 691 (M.D. Ala.), affd, 409 U.S. 942 (1972). Thus, there seems to be an open question concerning the applicability of these doctrines to attorney's fees awarded against the states and their officers. For more extensive consideration of this problem, see Cramton, Nonstatutory Review of Federal Administrative Action: The Need for Statutory Reform of Sovereign Immunity, Subject Matter Jurisdiction, and Parties Defendant, 68 Mrch. L. Rev. 387 (1970); Note, Environmental Litigation Fees, 58 CoRnell L. REv. 1222, 1246 (1973). See also note 327 infra.

25428 U.S.C. § 2412 (1970) provides:

Except as otherwise specifically provided by statute, a judgment for costs, as enumerated in section 1920 of this title but not including the fees and expenses of attorneys may be awarded to the prevailing party in any civil action brought by or against the United States or any agency or official of the United States acting in his official capacity ....

(Emphasis added.)

${ }_{255}$ Without this provision federal sovereign immunity would probably still bar awards against the federal government absent an affirmative indication that such immunity is waived. $C f$. West Central Mo. Rural Dev. Corp. v. Phillips, 42 U.S.L.W. 2366 
justification for retaining it in the light of the policy considerations just discussed. Combined with federal and state legislative provisions for a fund out of which courts would be authorized to award fees, this would eliminate the major legislative roadblocks to a more vital and effective role for private attorneys general. All that would be needed is the courts' continued response to the equities of the litigation before them.

\section{E. Conclusion}

The recent rapid development of the private attorney general theory of court awarded attorney's fees offers both a promise and a threat. The promise is one of greater access to the courts for those aspiring to vindicate the public interest. The threat is that conceptual confusion will prevent further development of this promise.

This Section has considered two approaches to the private attorney general fee award, corresponding to two understandings of the "public interest" in public interest litigation. The substantive approach to the definition of public interest seems most appropriate for a legislative, majoritarian determination. Thus courts, as the Fourth Circuit recognized in Bradley, should be wary of awarding fees to representatives of certain substantive interests and not to others. Legislative provision for fee awards should be the guide. ${ }^{256}$

A procedural approach, on the other hand, is more appropriate for the courts, as it is more neutral. Defining the public

(D.D.C., Dec. 21, 1973). The creation of a fund out of which the courts are authorized to award fees could be such a waiver.

There is some indication that the courts do not consider themselves completely without authority to award fees in suits against the federal government when there is no specific statutory provision for the award. In Pyramid Lake Paiute Tribe v. Morton, 360 F. Supp. 669 (D.D.C. 1973), the court awarded fees against the government even though there was no specific statutory authorization for the award, stressing the unique character of the suit. The suit was brought to enforce a fiduciary duty owed to the Tribe by the Secretary of the Interior, and the court cited two federal statutes, 25 U.S.C. $\S \S 175,476$ (1970), that authorize the United States Attorney to represent the Tribe in litigation and authorize the Tribe to employ legal counsel subject to the approval of the Secretary of the Interior. The court felt that the statutes provided in effect for an attorney's fee award in such a situation.

Read broadly, this case suggests that $\S 2412$ can be circumvented whenever the plaintiff complains of the government's failure to fulfill its duties under the law, leaving it to operate in cases in which the government acts as an essentially private party. But the unique features of the case would allow it to be limited to its facts in any future proceeding.

If the government is codefendant with one or more private parties, the burden of $\S$ 2412 on the plaintiff may be entirely removed. The court may simply award attorney's fees against the private defendants and not against the government, as was done in Sierra Club v. Lynn, 364 F. Supp. 834 (W.D. Tex. 1973).

256 Note, supra note 59 , at 336 contends:

Logically, one of two things must happen: either judicial discretion to grant fees on policy grounds [using the substantive approach] will result in universal fee shifting from the successful party, or the courts will withdraw to the traditional position, denying any fee transfer without specific statutory authorization. 
interest in terms of the opportunity for every significant interest to be heard enables the court to award fees to representatives of those interests that would not otherwise be able to appear. Thus the court is better able to make a fully informed decision and all interests affected by that decision will at least be fairly considered.

In making private attorney general fee awards, courts may also consider the "necessity of private enforcement" of the policy or right in question. This allows such awards to be made in instances where statutory or constitutional rights and policies would not otherwise be vindicated. This approach, as exemplified in the La Raza and Stanford Daily opinions, applies aspects of both the substantive and the procedural approaches to public interest litigation. Legislative or constitutional protection of a right or policy is a necessary condition to such an award, as is the court's determination that a party needs the award to be able to enjoy the benefit of the right or policy in question. Such awards are fairest when they are assessed against the state or federal public treasury, since the primary obligation to protect rights and enforce policies rests with public agencies.

Certain statutory reforms are necessary in order to completely carry out the private attorney general theory of fee awards. Public funds should be made available out of which courts could award fees for public interest representation, particularly under the procedural definition of the public interest. In addition, the federal government as litigant should allow itself to be assessed for attorney's fees by courts in appropriate cases. Although these reforms would not solve all problems of public interest representation, ${ }^{257}$ they would constitute a giant step toward realization of the universal goal of equal justice for all.

\section{Fee Awards to Legal Services}

As the number of cases in which attorney's fees are awarded under statutory or equitable authority has increased, questions have arisen concerning the propriety of such awards to Legal Services organizations, ${ }^{258}$ which are financed primarily by federal funds. ${ }^{259}$ This Section will explore the legality and desirabil-

${ }^{257}$ For example, these reforms would not meet the problems of financing very large-scale public interest litigation, where assured financing is needed throughout the course of the litigation. An assessed fee award at the conclusion of the litigation (if successful) would not realistically serve the purpose of private attorney general awards in such cases. Interim financing from public funds has been proposed. See Hearings, supra note 127 at 842 (Testimony of D. Flannery, Esq.).

${ }^{258}$ Awarding attorney's fees to Legal Services was first advocated in McLaughlin, The Recovery of Attorney's Fees: A New Method of Financing Legal Services, 40 FordHAM L. Rev. 761 (1972). That article makes specific suggestions as to when Legal Services might be awarded fees, especially under New York state law.

${ }^{259}$ The first OEO local Legal Services projects were funded in 1965 under general 
ity of such awards, their ability to effectuate policies underlying fee awards, and the advisability of ever awarding fees against Legal Services.

\section{A. Legal Services' Financial Need}

In civil law countries, legal aid for noncriminal litigation has a firm statutory basis, is securely built into the structure of judicial and professional organization, and is reasonably assured of continuity and long term financial support. ${ }^{260}$ By contrast, the American legal aid system rests on shaky footing indeed. Legal Services is insufficiently funded and has an excessive caseload per lawyer. ${ }^{261}$ American expenditures on legal aid are less than twice as high as British expenditures, even though the population is four times larger and the economy eight times greater. ${ }^{262}$ Estimates of the legal needs of poor people in the United States are grossly out of proportion to the resources actually available to serve them. ${ }^{263}$ Two recent New York decisions, in which Legal Services projects successfully contended that their overwhelming caseloads prevented them from accepting court assigned divorce $^{264}$ and landlord-tenant ${ }^{265}$ cases because of inability to provide the prompt and adequate representation called for by the $A B A$ Code of Professional Responsibility, ${ }^{266}$ provide a concrete illustration of this crisis in resources.

community action provisions of the Economic Opportunity Act of 1964, $\S \S 201-11,42$ U.S.C. $\$ \S 2781-837$ (1970). In 1966 an amendment to the Act gave specific authorization for the Legal Services program. See id. § 2809(a)(3).

Under normal circumstances no more than $80 \%$ of the cost of a Legal Services project may be covered by federal sources. See Economic Opportunity Act of 1964 , $\S$ 225(c), 42 U.S.C. \$ 2812(c) (1970). However, under authority granted under \& 225(c), OEO has adopted a rule providing that the federal share of funding may be $90 \%$ of costs for the first 32 months of a community action program, and may permanently be more than $80 \%$ in communities with certain characteristics. See 2 CCH Pov. L. REP. I 8020 (1972). The remaining share is contributed in cash or in kind by nonfederal sources ranging from state legislatures, see $i d$. $\Uparrow 8115.30$ (Vermont), to private charities and volunteer help.

The Act requires that all programs be developed, conducted and administered "with the maximum feasible participation of residents of the areas and members of the groups served." Economic Opportunity Act of 1964, § 202(a)(3), 42 U.S.C. \& 2791(f)(1) (1970).

260 R. Schlesinger, Comparative Law 278 \& $\mathrm{n.38}$ (3d ed. 1970).

${ }^{261}$ See Silver, The Imminent Failure of Legal Services for the Poor: Why and How to Limit Caseload, 46 J. URBAN L. 217 (1969).

${ }_{262}$ See Cappelletti \&c Gordley, Legal Aid: Modern Themes and Variations, Part One, 24 STAN. L. REv. 347,379 n.210 (1972). This comparison remains meaningful even in the face of $O E O$ estimates that American-style programs can furnish aid at one-third the cost of British-style programs, id. $362 \mathrm{n} .89$, because of the difference in quality of work due to size of caseload. Id. Part Two, 413 \& nn.100-05.

${ }^{263}$ Former OEO Director Frank Carlucci has estimated that the Legal Services program is meeting only $28 \%$ of poor people's need for counsel in civil matters. Hearings on H.R. 40, H.R. 185, H.R. 357, etc. E' Oversight on the Administration E' Extension of the Economic Opportunity Act Before the House Comm. on Education \& Labor, 92d Cong., 1st Sess. 1566-67 (1971).

${ }_{264}$ See Vanderpool v. Vanderpool, 40 App. Div. 2d 1030, 339 N.Y.S.2d 657 (1972) (mem.).

${ }^{265}$ See Tobak v. Mojica, No. 66859-72 (N.Y. Sup. Ct., App. Term, May 11, 1973), 7

Clearinghouse Rev. 167 (1973) (Doc. No. 10,290B).

${ }_{266}$ ABA Code of Professional Responstbility, Canon 2. 
Against this ominous background, the possibility of Legal Services recovering attorney's fees, even if only in a small number of cases, promises welcome relief. Any fees recovered by a Legal Services project, generated purely as a byproduct of its regular operation, could be applied to everyday needs of the office or, if sufficiently large, to expanding its legal staff. This would allow Legal Services a better chance of adequately fulfilling its objective of aiding the poor. ${ }^{267}$ At the same cost to the taxpayer, Legal Services could operate an expanded program.

Legal Services has been severely criticized for the way it has gone about meeting the needs of the poor, apparently because law reform policies which evolved side-by-side with everyday client services as the dual thrust of the program struck many people as being too far removed from the everyday legal needs of the poor or too threatening to the existing social order. ${ }^{268}$

${ }^{267}$ The overall objectives of the Legal Services program are:

First: To make funds available to implement efforts initiated and designed by local communities to provide the advice and advocacy of lawyers for people in poverty.

Second: To accumulate empirical knowledge to find the most effective method to bring the aid of the law and the assistance of lawyers to the economically disadvantaged people of this nation. OEO will encourage and support experiment and innovation in legal services proposals to find the best method.

Third: To sponsor education and research in the areas of procedural and substantive law which affect the causes and problems of poverty.

Fourth: To acquaint the whole practicing bar with its essential role in combating poverty and provide the resources to meet the response of lawyers to be involved in the War on Poverty.

Fifth: To finance programs to teach the poor and those who work with the poor to recognize problems which can be resolved best by the law and lawyers. The poor do not always know when their problems are legal problems and they may be unable, reluctant, or unwilling to seek the aid of a lawyer.

OEO, Guidelines for Legal Services Programs, 2 CCH Pov. L. ReP. If 8010 (1972).

${ }^{268}$ Former Vice President Agnew, for example, probably set forth the Nixon

Administration's view of the failings of the Legal Services program when he declared:

[W] hat we have is the Federal Government funding a program designed to effectuate major political changes. What we may be on the way to creating is a federally funded system manned by ideological vigilantes, who owe their allegiance not to a client . . . but only to a concept of social reform.

... Isn't it possible that we have gone too far when the Federal Government constructs a program which encourages individual lawyers to test at public expense their own individual theories of how society should be structured and how the resources, rights and benefits of that society should be distributed among the population?

Agnew, What's Wrong with the Legal Services Program, 58 A.B.A.J. 930, 931 (1972). See also the remarks of Rep. Conlan concerning Legal Services practices.

In this situation there are staff attorneys who are interested in causes. They concentrate on high impact cases, appeals and class actions .... .

In case after case ... these staff attorneys were not taking the bread and butter cases of helping the poor. What happened to the poor? They were thrown into the revolving door, out on the streets, because the staff attorneys did not make enough time.

119 Cong. REc. 5108 (daily ed., June 21, 1973).

The history of Legal Services is replete with efforts to halt the law reform aspect of the program. In the late sixties former Senator Murphy of California introduced two amendments to antipoverty legislation, neither of which passed, to prevent the use of 
Such criticism appears unfounded in light of Legal Services' impressive national success record of winning eighty percent of cases litigated, and settling sixteen percent of all cases out of court. ${ }^{269}$ The law reform policy was tentatively stated in 1965 as follows:

In some areas, the law ... is either unclear or is detrimental to the interests of the poor. The proposal should consider the role of the legal service program in defining or changing such law. This may include judicial challenge to particular practices and regulations, studies of whole areas of the law in advance, research into conflicting or discriminatory applications of law or administrative rules, and proposals for administrative and legislative change. ${ }^{270}$

The award of fees to Legal Services in appropriate cases would help remove the bases of these arguments against Legal Services' broad attack on the legal roots of poverty. Many types of cases in which courts may award fees are cases which have an impact on classes of people. If fees were awarded to Legal Services in such cases, it would mean filling real needs of poor people while at the same time replacing the resources expended. Thus Legal Services would be able to handle cases of broad impact without depleting the legal resources available to serve the "bread and butter" needs of the poor.

The award of fees to Legal Services would thus provide a much-needed financial boost so that the program could more adequately provide advice and advocacy for people in poverty. This is a factor which a judge should consider in determining

Legal Services funds to sue a governmental agency and to give state governors an absolute veto over a Legal Services program. There have been several cases where state officials have attempted to halt law reform activity by vetoing programs, although OEO subsequently overrode the vetoes. ABA SEction on INDIvidual RigHTS \& RESPONsibilities \& Standing Committee on Legal Aid \& Indigent Defendants. The Corporation for Legal. Services 14-15 (1971) (joint informational report).

${ }^{269}$ See 119 Cong. Rec. 5109 (daily ed. June 21, 1973) (Remarks of Rep. Meeds, referring to a General Accounting Office report on Legal Services). It is not clear how much of this success record is due to the careful selection of cases to be litigated.

270 Bureau of Social. Science Research, INC., A CoMparative ANAlysis of Alternative Strategies for the Provision of Legal Services to the Rural Poor 10 (Draft Rep. June 1971), quoting U.S. OfFice of Economic Opportunity, Dep'T of Health, Education \& Welfare, Tentative Guidelines for Legal Service Proposals to the OFFICE OF ECONOMIC OPPORTUNITY (1965). The Legal Services Corporation Bill, passed by the House in June of 1973, 119 CoNG. REc. 5067-138 (daily ed. June 21, 1973), seems specifically designed to thwart these priorities; it would abolish backup centers (regional research and strategy centers), prohibit administrative and legislative advocacy, and forbid any Legal Services attorney from engaging in partisan or nonpartisan political work. See H.R. 7824, 93d Cong., 1st Sess. (1973). The Senate version of the Bill, S. 2686, 93d Cong., 1st Sess. (1973), does not prohibit back up centers and is less restrictive with regard to political advocacy by Legal Services personnel. It was passed by the Senate in January of 1974. 120 Cong. Rec. S. 905-1012 (daily ed. Jan. 31, 1974). 
how to exercise his discretion in a case which would normally be fee generating. ${ }^{271}$

\section{B. Absence of Initial Barriers \\ 1. Proper Recipient}

Assuming that an attorney's fee is to be awarded, who would be the proper recipient in a case in which the winning party is represented by Legal Services? There are four possible answers to this question: the client, the attorney, the federal government, or Legal Services itself.

To pay such an award to the indigent himself, when he has received legal assistance free of charge, would be to give him an unwarranted windfall. The district court in White $v$. King ${ }^{272}$ recognized this when it ruled that it was within the court's discretion not to award fees, absent a showing that they would be contributed to the Legal Services organization. On the other hand, it would be impossible to award fees to the salaried attorney himself since a Legal Services attorney may not accept compensation for any case handled in his official capacity or through Legal Services. ${ }^{273}$

The third alternative is to make the award to the contributors of Legal Services' funds. One court considered this possibility, finding it logical to award the fees to Legal Services' supporters who "technically should have the right to allocate the award at their option either to Legal Aid or their own coffers."274 However, this procedure was rejected because of administrative problems. A New Jersey court in a divorce action ${ }^{275}$ made the fee award payable to the United States Treasury, on the theory that taxpayers should not have to bear the financial burden when normally the husband would have to pay his wife's counsel fees. The question therefore becomes whether Legal Services has a stronger claim to this potential fund than the taxpayer.

The amount of federal money spent to serve the legal needs of the poor is properly set by congressional appropriation. However, the federal government is not the sole supporter of Legal Services as its total funding level is also determined by state and local appropriations and private contributions. ${ }^{276}$ To contend

${ }^{271} C f$. Woolfolk v. Brown, 358 F. Supp. 524, 536 (E.D. Va. 1973) (court took judicial notice of Legal Services' waiting lists as support for Legal Services' contention that time spent on contempt motions resulted in the denial of legal services to others).

272319 F. Supp. 122, 127 (E.D. La. 1970). (1972)

${ }^{273}$ See OEO, Guidelines for Legal Services Programs, 2 CCH POV. L. REP. I 8700.44

${ }_{274}$ Woolfolk v. Brown, 358 F. Supp. 524, 536 n.5 (E.D. Va. 1973).

${ }^{275}$ Ferrigno v. Ferrigno, 115 N.J. Super. 283, 279 A.2d 141 (Ch. 1971).

${ }^{276} \mathrm{See}$ note 259 supra. 
that any fees which are generated by Legal Services lawyers should be returned to the federal treasury is to treat the federal contribution as an investment, which it is not. It is a grant to provide legal services to the poor, and Congress surely did not contemplate that it would be partially returned through the efforts of Legal Services attorneys. Rather, court-awarded attorney's fees should be viewed as forced supplemental contributions to a local Legal Services organization, channelled through the judicial system.

Most significantly, the award of fees to Legal Services would allow a Legal Services attorney the opportunity to increase, by his skill, the amount of legal aid available to the poor people of his community, and thereby further the policies implicit in federal funding of the program. This point is especially important in view of the present financial crisis of Legal Services and the many pressing needs of the poor. ${ }^{277}$ Since neither the client nor the individual attorney has a valid claim to the fee award, and the federal government has at best a weak one, the most appropriate recipient of court awarded fees is the local Legal Services organization.

\section{Competition with the Private Bar}

Legal Services organizations would not be entering into competition with the private bar by accepting court awarded fees. By regulation and actual practice, the cases which Legal Services takes are those which the private bar will not accept, even though some turn out to be fee generating. The OEO Guidelines for Legal Services Programs on this issue are clear:

Programs should not provide free legal advice in feegenerating cases, such as contingent fee cases or other cases in which a fee provided by statute or administrative rule is sufficient to retain an attorney. The test should be whether a client can obtain representation. When a case generates a fee sufficient to employ competent private counsel, the client should be referred under an appropriate lawyer referral system. If the fee is not sufficient to attract a private lawyer, the client may

${ }^{277}$ See Silver, The Imminent Failure of Legal Services for the Poor: Why and How to Limit Caseload, $46 \mathrm{~J}$. UrBan L. 217, 221 (1969). Silver suggests that 257,800 lawyers would be needed to serve the poor in the United States, on the assumption that 5 times as much attorney input is required to provide the same level of representation to poor as to middle-class clients. As of 1969 there were only 200,600 lawyers in private practice in the United States. See also note 263 supra.

For the past three years Legal Services has operated on continuing appropriations, which do not even reflect cost-of-living increases. Interview with Laurence H. Hamblen, OEO Legal Services Regional Director, Region III, in Philadelphia, Pennsylvania, Dec. 1973. 
be eligible for the assistance of the OEO-funded program. ${ }^{278}$

In Alameda County, California, for example, where Legal Services has referred clients seeking review of welfare hearing decisions to the County Bar Association Lawyer Referral Service, the Service has been unable to secure the assistance of private attorneys ${ }^{279}$ even though the award of fees in such cases is authorized by statute. ${ }^{280}$ The former Western Regional Director of OEO Legal Services has stated that the private bar is uninterested in such welfare cases. ${ }^{281}$ Therefore when Legal Services in Alameda County prevails in a hearing review proceeding and is awarded fees under the relevant statutory provision, ${ }^{282}$ it has not taken a fee away from the private bar but has merely provided legal aid to a person who would otherwise have remained unrepresnted.

The crucial decision, vis-à-vis competition with the private bar, occurs at the time a case is accepted. Whether or not Legal Services is awarded attorney's fees upon the completion of a case is irrelevant to competition, since the case was one which the private bar was unwilling to take initially. If adequate fees are consistently awarded to Legal Services, such cases may become more attractive to private attorneys. Legal Services should be glad to broaden the base of the struggle against poverty by turning these cases over to private attorneys, and free its resources to handle other cases which private attorneys will not handle. If Legal Services organizations continue to refer potentially fee generating cases to the private bar, there will be no conflict between the acceptance of court awarded fees by Legal Services and the ban against competition. ${ }^{283}$

278 OEO, Guidelines for Legal Services Programs, 2 CCH Pov. L. REP. I 8700.35 (1972).

One commentator has advanced the view that the possibility of a traditional contingent fee arrangement should not make a client ineligible for legal aid when he seeks to recover only out-of-pocket losses, and would be financially eligible for Legal Services even after the recovery. See Comment, 4 Harv. Civ. Rights-Crv. Lib. L. Rev. 415 (1969).

${ }^{279}$ See Brief for Appellee at 23-24, Bell v. Carleson, Civil No. 1-32930 (Cal. App., filed July 17, 1973) (available from National Clearinghouse for Legal Services, Doc. No. $10,782 \mathrm{~A}$ ).

${ }^{280}$ CAL. Welf. \& INST'NS CODE $\S 10962$ (West 1972).

281 See Brief for Appellee at 22-24, Bell v. Carleson, Civil No. 1-32930 (Cal. App. filed July 17, 1973), (quoting affidavit of Thomas Mack). Mr. Mack attributes this lack of interest to the extreme complexity of welfare law which requires specialized expertise. He concludes that:

Despite the Legislature's attempt by providing for attorney's fees to stimulate the interest of the private bar, such cases would not be handled if legal services did not handle them, except where they come within the limited interests of organizations like the ACLU, Welfare Rights, NAACP, Synanon, etc.

Id. at 24 .

${ }^{282}$ See, e.g., Bell v. Carleson, Civil No. 426494 (Cal. Super. Ct., Alameda Co. 1972).

${ }^{283}$ The extent to which these fee-generating cases involving the poor would be taken by private attorneys even if fees were consistently awarded is open to question. Fees awarded in such cases are "reasonable" attorney's fees, in contrast to (usually) higher 


\section{The Client's Obligation to Pay His Attorney}

Many parties losing to a complainant represented without cost by Legal Services or pro bono counsel have raised the objection that it is senseless to award attorney's fees to a person who does not have to pay his attorney. ${ }^{284}$ This argument as to privately funded organizations such as the NAACP Legal Defense and Education Fund, Inc. and Public Advocates, Inc. has been rejected by several courts in landmark attorney's fees cases. ${ }^{285}$

In Clark v. American Marine Corp. ${ }^{286}$ a case in which a major portion of the plaintiff's case was handled by a staff attorney of the NAACP Legal Defense and Education Fund, Inc., the court held that the relevant consideration was not the presence, absence, or amount of any fee agreement between the lawyer and his client, but rather the amount of a reasonable fee, ${ }^{287}$ as the statute provided for the award of fees to the prevailing party and not to the lawyer. Miller v. Amusement Enterprises, Inc., ${ }^{288}$ also participated in by the Legal Defense and Education Fund, explicitly rejected the argument that an obligation to pay attorney's fees is a condition precedent to the award of fees, holding that only the existence of an attorney-client relationship is required. ${ }^{289}$ The court described this relationship as a status which exists independently of compensation, giving as one example "the now widespread organized [legal] services on behalf of the poor."290 Moreover, were courts to require an obligation

contingent fees. Contingent fees are typically in excess of what would be charged if a straight hourly rate were used, to make up for costs incurred in lost cases for which no fee is received. See generally ABA Code of Professional Responsibility, DR 2-106(B)(8) (1969). Also, in many Legal Services cases the recovery is small or relief is injunctive only, neither of which are likely to generate a very large fee.

Even if a substantial case is won and a fee is awarded, it is unlikely to produce a fee attractive to a private attorney. For example, in Wyatt v. Stickney, 344 F. Supp. 387, 410 (M.D. Ala. 1972), a suit which helped to establish minimum constitutional standards for mental health institutions, the court found $\$ 30$ per in-court hour and $\$ 20$ per out-ofcourt hour to be a reasonable basis for computing fees, even though it recognized that these rates are below normal levels of compensation in private legal practice.

Finally, the lawyer has to contend with the large amount of discretion in setting the fee award vested in the trial judge, see Cooper v. Allen, 467 F.2d 836 (5th Cir. 1972) (denial of attorney's fees has typically been overturned "only upon a showing of abuse of discretion"), which greatly limits the lawyer's remedy when he feels that the award has been wrongly denied or determined. But see Newman v. Piggie Park Enterprises, Inc., 390 U.S. 400, 402 (1968) (greatly narrowing the discretion of the trial judge in certain situations where fees are authorized by statute).

${ }^{284}$ See, e.g., Lea v. Cone Mills Corp., 438 F.2d 86, 89 (4th Cir. 1971) (Boreman, J., dissenting in part).

${ }^{285}$ See Lee v. Southern Home Sites Corp., 444 F.2d 143 (5th Cir. 1971); Lea v. Cone

Mills Corp., 438 F.2d 86 (4th Cir. 1971).

286320 F. Supp. 709 (E.D. La. 1970), affd, 437 F.2d 959 (5th Cir. 1971).

${ }^{287}$ For a discussion of the difficulties of determining a "reasonable" fee award, see Section IV infra.

${ }^{288} 426$ F.2d 534 (5th Cir. 1970).

${ }^{289}$ See id. at 538-39.

${ }^{290} I d$. 
on the part of the client to pay his attorney as a condition precedent to a fee award, this requirement could easily be circumvented by a formal agreement limiting the attorney's compensation to whatever fees might be awarded by the court. ${ }^{291}$

Case law therefore indicates that making the client whole is not the only reason for awarding fees. The fact that a Legal Services client has no obligation to pay the organization for legal aid received should be no bar to a court awarded fee to Legal Services. The fact that private nonprofit organizations were involved in the cases cited above, rather than governmentfunded Legal Services, should make no difference in the result when a fee award is mandated by statutory provision or policy.

\section{Effectuation of Purposes Underlying Fee Awards}

The single most important consideration involved in awarding fees is the effectuation of the policies and purposes behind the award. Careful examination of the rationales behind the major equitable exceptions to the restrictive American Rule ${ }^{292}$ and certain statutory provisions allowing such awards reveals that these policies and purposes are served as well, with one exception, by the award of fees to the litigant represented by Legal Services as by the award of fees to those represented by private counsel.

\section{Bad Faith and Obstinacy}

The first exception to the American Rule is straightforward: the court may shift the costs of litigation to a party who acted in bad faith, ${ }^{293}$ refused to act rightfully when his duties under the law were clear, ${ }^{24}$ put the opposing party to unnecessary expense, ${ }^{295}$ or engaged in frivolous litigation, dilatory tactics or harassment. ${ }^{296}$ Included also is the practice of awarding fees to

291 This type of agreement was made by the appellee and Legal Services in Bell v. Carleson, Civil No. 1-32930 (Cal. App., filed July 17, 1973). See Brief for Appellee at 17, id.

${ }^{292}$ For an extended discussion of the Rule, see notes $1-47$ supra \& accompany text.

${ }^{293}$ See, e.g., Bell v. School Bd., 321 F.2d 494, 500 (4th Cir. 1963).

${ }^{294}$ See, e.g., Vaughan v. Atkinson, 369 U.S. 527, 530-31 (1961) (admiralty case).

${ }^{295}$ The Federal Rules of Civil Procedure make specific provision for attorney's fees to be awarded in such situations. For example, FED. R. CIv. P. 37(c) provides:

If a party fails to admit the genuineness of any document or the truth of any matter as requested under Rule 36 , and if the party requesting the admissions thereafter proves the genuineness of the document or the truth of the matter, he may apply to the court for an order requiring the other party to pay him the reasonable expenses incurred in making that proof, including reasonable attorney's fees. The court shall make the order unless ... (3) the party failing to admit had reasonable ground to believe that he might prevail on the matter....

${ }_{296}$ See Annot., 8 L. Ed. 2d 894, 912-13 (1962). For a discussion of the recent expansion of this exception, see notes $157-63$ supra \& accompanying text. For a discussion 
the prevailing plaintiff in a contempt action. ${ }^{297}$ The purpose of such awards seems to be twofold: first, to reimburse one party for unnecessary litigation expenses, and second, to punish the party at fault and to deter him and others from such conduct in the future. ${ }^{298}$

In regard to the first purpose, it is as unjust for a Legal Services organization to have to use its limited resources to counteract wrongful conduct and bad faith litigation as it is for a private party. To deplete unnecessarily such resources frustrates the legislative goal and diminishes the legal assistance available to those eligible for Legal Services.

The second purpose, to punish and deter future wrongful conduct, is of special importance to litigation involving people eligible for Legal Services. Such people, because of their lack of economic power, are apt to be especially vulnerable to such conduct. For example, in Silberzweig $v$. Masino ${ }^{299}$ a landlord had brought several false rent proceedings against a tenant within a few months. The tenant won on a counterclaim for damages for abuse of process and harassment, and the court granted fees to Legal Services, which represented the tenant. Particularly when poor people are involved, obstinacy, harassment and frivolous claims should be deterred and punished, to deter the opposing party from taking advantage of the powerlessness of the poor. Failure to assess fees against a party who acted wrongfully, merely because the other party was represented by a Legal Services attorney, in effect thwarts the policy of deterrence where it is most needed and creates an undeserved windfall for the party at fault.

Recognition that failure to award fees would nullify this policy of deterrence was probably the basis for the district court's award in Quad-Cities Community News Service, Inc. v. Jebens, ${ }^{300}$ a

of the possible use of an expanded version of this exception to alleviate some of the problems created by the American Rule, see notes 87-158 supra \& accompanying text.

297 See Annot., 8 L. Ed. 2d 894, 911-12 (1962).

${ }^{298}$ Cases in which counsel fees are taxed against the losing party under a bad faith or obstinacy rationale are notably reticent about exploring fully the purposes behind such awards. That one purpose is to compensate the party who has been inequitably forced to expend funds unnecessarily is explicit. See, e.g., Vaughan v. Atkinson, 369 U.S. 527, 531 (1961) ("As a result of that recalcitrance libellant was forced to hire a lawyer and go to court to get what was plainly owed him under laws that are centuries old."). That such an award also serves to punish the guilty party and deter him from vexatious and oppresive conduct in the future is implicit. See Hall v. Cole, 412 U.S. 1, 5 (1973); Gazan v. Vadsco Sales Corp., 6 F. Supp. 568, 568 (E.D.N.Y. 1934) ("Plaintiff in bringing this action has been engaged in a fishing expedition .... . Every fisherman, including novices, realizes that any one who contemplates a fishing trip must be prepared to pay the expenses."). It has been suggested that the fee is taxed primarily to punish the losing party's bad faith. See McLaughlin, supra note 258 , at 768 .

${ }^{299} 164$ N.Y.L.J., Nov. 17, 1970, at 20 (N.Y. Civ. Ct.).

${ }^{300}$ Civil No. 4-989-D (S.D. Iowa 1971). See also Jeffries v. Weaver, No. 70-3196 (N.D. IIl. 1972) (fees awarded to Legal Services in case where counsel was required to attend 3 unnecessary hearings because of defendant's continued delay in carrying out the court's 
suit to vindicate the constitutional rights of the publishers of an underground newspaper. The court awarded $\$ 150$ as attorney's fees to Legal Services lawyers because the defendant police department deliberately went through the trial process without any hope of prevailing on the merits, failed to file any pleadings, and did not make any arguments. The court made no issue of the fact that the recipient of the fee was a Legal Services organization. Similarly, in In re Souza ${ }^{301}$ the Court of Appeals for the First Circuit awarded attorney's fees of $\$ 250$ to Rhode Island Legal Services under rule 38 of the Federal Rules of Appellate Procedure. Rule 38 provides for damages and award of single or double costs to an appellee when the court finds an appeal to be frivolous. The defendants, correctional officials, had failed to seek a stay or an expedited appeal of a judgment allowing a physician and photographer into a correctional institution to obtain proof of plaintiff's injuries from alleged police beatings. The judgment had been fully implemented by the time of the appeal, and so the circuit court dismissed it as moot.

In Woolfolk $v$. Brown, ${ }^{302}$ a case noteworthy because it attempts to create a methodology for determining whether to award fees to a Legal Services organization, ${ }^{303}$ a contrary result was reached. Although the court found that the state welfare department "wilfully, and without reasonable belief in the correctness of their actions and the law, disobeyed and violated an injunction," 304 and that an award would have been proper under the obstinacy exception if plaintiff had been represented by a private attorney, it found certain policy factors missing which were requisite, in its view, for an award to Legal Services. ${ }^{305}$ The court took judicial notice of Legal Services' waiting lists as support for the argument that time spent on the contempc case denied legal services to others, but absent the requisite policy factors the court found insurmountable the problems associated with the award of fees from the state welfare budget, and did not find sufficient personal misconduct to hold the defendants per-

order). But see Gaddis v. Wyman, 336 F. Supp. 1225 (S.D.N.Y. 1972), in which welfare department officials were found in civil contempt. The court offered as grounds for the denial of the requested fee award the fact that Legal Services lawyers are OEO funded and that the attorneys did not use any of their private funds in the suit. An underlying ground for the denial, however, was that the defendants did not willfully disobey or defy the injunction. The court found that the defendants' denial of aid was due to bureacratic anticipation of new legislation. See id. at 1227.

${ }^{301}$ No. $72-1184$ (1st Cir. 1972).

302358 F. Supp. 524 (E.D. Va. 1973).

${ }^{303}$ The court suggested that three considerations were relevant to the award of attorney's fees: (1) whether the circumstances of the litigation merit attorney's fees under doctrines of equity as applied to private attorneys and parties; (2) the potential recipient of an award; and (3) the party to be taxed. Id. at 536-37.

${ }^{304}$ Id. at 535 .

${ }^{305}$ See text accompanying note 306 infra. 
sonally liable. Such a result fails to deter one party from wrongful conduct and fails to compensate the other party for wasted resources. Whenever fees would be awarded to the client of a private attorney under an obstinacy rationale, the same considerations support an award to Legal Services.

\section{Private Attorney General}

The court in Woolfolk did conclude that fee awards to Legal Services would be proper when certain policy factors are present, including a statutory expression of congressional intent or strong precedent indicating that the purpose of an award is either to make violators rather than victims or the public bear the cost of enforcement of a policy, or to stimulate private enforcement of a public policy. ${ }^{306}$ These factors underlie the private attorney general rationale for awarding attorney's fees to successful plaintiffs. In accordance with this conclusion, the same court awarded fees in Jones $v$. Seldon's Furniture Warehouse, Inc. ${ }^{307}$ to Legal Services under the attorney's fee provision of the Truth-inLending Act. ${ }^{308}$ The court found that the statute was intended to promote private enforcement, and that legislative history expressed a strong public policy in regard to credit transactions. The court felt that the award to Legal Services was consistent with the purposes of the legislation:

Creditors will be placed on notice that consumers will have greater access to help from legal services projects, which by virtue of an award of fees might be freer to allocate their time to consumer credit cases. This in turn may more effectively influence creditors to avoid running afoul of the law. ${ }^{309}$

Other courts have agreed that fees should be awarded to Legal Services under the private attorney general rationale. In United States $v$. Texas, ${ }^{310}$ a district court awarded fees to a Legal Services project in a civil rights case covered by no statutory fee provision. The decision in a sex discrimination case, Doe $v$. Osteopathic Hospital of Wichita, Inc., ${ }^{311}$ awarded fees to a legal aid society under the discretionary fee award provision of Title VII

${ }^{306}$ See 358 F. Supp. at 536.

${ }^{307} 357$ F. Supp. 886 (E.D. Va. 1973).

${ }^{308} 15$ U.S.C. \& 1640 (a)(2) (1970). Accord, Settle v. Mallicott Auto Sales, Inc., Civil No. 71-238 (D. Ore. 1972). But see Owens v. Modern Loan Co., Civil No. 7298-A (W.D. Ky. 1972) (illogical to award fees to Legal Services because Legal Services was performing its intended function, and the principle of such an award, compensation for funds expended, was inapplicable).

${ }^{309} 357$ F. Supp. at 888.

${ }^{310}$ Civil No. 5281 (E.D. Tex., Apr. 30, 1973).

311333 F. Supp. 1357 (D. Kan. 1971). 
of the Civil Rights Act of 1964..12 And Taylor v. City of Millington $^{313}$ awarded fees to a Legal Services organization under section 812(c) of the Fair Housing Act of $1968^{314}$ on the authority of Newman v. Piggie Park Enterprises, Inc., ${ }^{315}$ the Supreme Court archetype of private attorney general litigation. ${ }^{316}$

In conflict with these authorities stands Ross $v$. Goshi, ${ }^{317}$ a freedom of speech case..$^{318^{-}}$The court, although granting fees under a private attorney general rationale to plaintiffsintervenors represented by private counsel, denied fees to the Hawaii Legal Services Project on the ground that Legal Services attorneys can function as private attorneys general without court awarded fees because of their government funding. The court, pointing out that the private attorney general function is one of the underlying reasons for a Legal Services program, found no "necessity" for a fee award under the La Raza Unida test:

[W]henever there is nothing in a statutory scheme which might be interpreted as precluding it, a "private attorney-general" should be awarded attorneys' fees when he has effectuated a strong Congressional policy which has benefited a large class of people, and where further the necessity and financial burden of private enforcement are such as to make the award essential. ${ }^{319}$

It is true that the private attorney general exception is intended to promote suits to enforce government policies in areas which depend on private enforcement, and to compensate those who litigate in the public interest. ${ }^{320}$ In theory, then, Legal Services does not need fees to motivate and enable it to represent poor people in areas of special concern to them. It is important

31242 U.S.C. $\$ 2000 \mathrm{e}-5(\mathrm{k})(1970)$.

Although the court did not discuss the purpose behind the fee provision or the propriety of awarding fees to Legal Services, awarding fees in Title VII cases has been interpreted consistently to be an expression of the private attorney general rationale. See, e.g., Clark v. American Marine Corp., 320 F. Supp. 709, 710-11 (E.D. La. 1970), aff d, 437

F.2d 959 (5th Cir. 1971).

${ }^{313}$ Civil No. $71-249$ (W.D. Tenn. 1972).

31442 U.S.C. $\$ 3612$ (c) (1970).

315390 U.S. 400 (1968); see notes 132-35, 184 supra \& accompanying text.

${ }^{31} 6$ See also Schuman v. Meyers, No. 210432 (Wash. Super. Ct., Spokane Co., June 5, 1973), where fees were awarded to Legal Services in an action brought under a state consumer protection statute which contained a discretionary fee provision clause.

317351 F. Supp. 949 (D. Hawaii 1972).

${ }^{318}$ The action was brought under 42 U.S.C. $\$ 1983$ (1970).

${ }^{319}$ La Raza Unida v. Volpe, 57 F.R.D. 94, 98 (N.D. Cal. 1972).

${ }^{320}$ In many "public interest" cases only injunctive relief is sought, and the average attorney or litigant must hesitate, if not shudder, at the thought of "taking on" an entity such as the California Department of Highways, with no prospect of financial compensation for the efforts and expenses rendered. The expense of litigation in such a case poses a formidable, if not insurmountable, obstacle.

Id. at 101 . 
to realize, however, that almost all suits to which the private attorney general rationale is applicable benefit the whole population through the enforcement and improvement of public policy. As Judge Peckham said in La Raza: "[E]nvironmental protection, housing relocation, and highway construction are nearly everyone's business, and ... almost all of society is better off when public policies in these areas have been strengthened."321

If the wining plaintiff in that case, or in a free speech, civil rights or due process case, were represented by Legal Services, to deny fees would result in the poor people of a community bearing alone, in terms of a reduction in the level of legal services available to fill their needs, the financial burden of effectuating strong congressional policies which benefit the whole population. In order to have the general public rather than a particular segment of the poor bear the cost, resources expended by Legal Services in a suit to which the private attorney general rationale was applicable would have to be replaced by general federal funds. It is illogical to put the cost of enforcement on violators when the plaintiff is represented by private counsel, and on the public or the poor when the plaintiff is represented by Legal Services. Fees should also be allowed in favor of Legal Services and against the losing party under the private attorney general rationale. ${ }^{322}$

Contrary to the reasoning of the Ross court, as long as Legal Services has an excessive caseload ${ }^{323}$ and the legal needs of all the poor are not adequately served, there is a need to award fees to Legal Services. Denial of fees is a penalty against Legal Services and detracts from the opportunity of poor people to act as private attorneys general, with costs to be covered by the violators of the policy vindicated. The burden of enforcement in private attorney general cases should not depend upon the presence or absence of Legal Services attorneys in the case. Otherwise violators will receive an undeserved windfall in the form of reduced liability, solely because of Legal Services' presence in the case.

\section{Common Fund}

A third major equitable exception to the American Rule is the common fund rationale. Fees are awarded under this

${ }^{321}$ Id. at 100 .

322 If the system of fee awards from public funds in private attorney general cases proposed in the preceding Section were adopted, see notes 248-55 supra \& accompanying text, then Legal Services should receive the award from the public treasury like any other litigant. As explained in the text, such private attorney general suits benefit the whole public through the enforcement of public policy, and it would be unjust to tax the poor for the cost of such suits when it has been determined that the general public should bear their cost.

${ }^{323}$ The court in Woolfolk v. Brown, 358 F. Supp. 524, 536 (E.D. Va. 1973), took judicial notice of local Legal Services waiting lists. 
rationale out of a fund recovered or maintained by the plaintiff, on the theory that all who will participate in the fund should pay the cost of its creation or protection and that this is best achieved by taxing the fund itself for attorney's fees. ${ }^{324}$ Legal Services attorneys should not accept fees in most common fund cases, since Legal Services may not accept fees from clients or receive a part of the client's recovery. ${ }^{325}$

The court in Woolfolk $v$. Brown ${ }^{326}$ refused for this reason to award fees under the common fund theory, even though they could have been awarded under an obstinacy rationale. Assuming that fees could be awarded only from recovered funds earmarked for distribution to welfare recipients, and not from the state treasury because of the proscription of the eleventh amendment, ${ }^{327}$ the court concluded that it would be inequitable to tax welfare recipients' benefits to pay attorney's fees to Legal Services, and that Legal Services would not wish it. ${ }^{328}$ This reasoning would be applicable in any common fund case in which the class to receive the fund is composed of poor people who need all of the recovery.

In some cases in which fees may be recovered under a common fund rationale, Legal Services should not be so constrained. There are cases in which fees, although justified on the basis of a common fund theory, are actually awarded out of the pocket of the defendant. Sometimes the defendant is seen as the personification of those who benefited from the fund, ${ }^{329}$ and sometimes as the only feasible entity to tax. For example, in

${ }^{324}$ For a discussion of the recent expansion of this rationale, see notes 164-83 supra $\&$ accompanying text.

${ }^{325}$ For example, Legal Services refuses any fees awarded in connection with Social Security benefits, as they would come out of the claimant's recovery. Interview with Laurence H. Hamblen, OEO Legal Services Regional Director, Region III, in Philadelphia, Pennsylvania, Dec. 1973. See also McLaughlin, supra note 258, at 778 .

326358 F. Supp. 524 (E.D. Va. 1973).

${ }^{327}$ Id. at 537 .

Because of the 11th amendment proscription, the Woolfolk court concluded that attorney's fees could only be recovered from funds slated for disbursement to the welfare recipients, and not from nondistributable funds allocated to the budget of the Virginia State Welfare Department. The court was not clearly correct in this conclusion. In Sims v. Amos, 340 F. Supp. 691 (M.D. Ala.), aff'd, 409 U.S. 942 (1972), the court awarded attorney's fees against Alabama state legislators and officials under the private attorney general rationale. It held that the defendants were not immune, because they had consistently refused to reapportion the state legislature when it was clear that they were under a duty to do so. The suit was brought to force the defendants to fulfill this duty and the court concluded that the defendants should be held responsible for the costs of their deliberate failure to act. Thus, in certain egregious circumstances, fees are awardable against state officials personally. See also note 253 supra.

${ }^{328}$ See 358 F. Supp. at 537. Strictly speaking, the court's language on this issue is dictum, as the case did not satisfy the other criteria for awarding fees to Legal Services.

${ }^{329}$ See Hall v. Cole, 412 U.S. I (1973) (fees awarded against union on the theory that all union members benefited from plaintiffs suit); Bright v. Philadelphia-BaltimorcWashington Stock Exch., 327 F. Supp. 495 (E.D. Pa. 1971) (fees awarded against the exchange, justified in part on the theory that the entire exchange and its members had benefited from plaintiff's suit). 
Brewer v. School Board ${ }^{330}$ the court awarded fees against the school district, reasoning that although the plaintiffs had created a "common fund" by securing a right to transportation valued at sixty dollars per school child per year, which warranted a contribution toward attorney's fees from each school child, to tax the fees against the benefiting school children would be impractical and would defeat the basic purpose of the relief, which was to provide transportation to them without cost. When the defendant is required to pay, even in common fund cases Legal Services should recover fees the same as a private attorney; Legal Services would not be breaching its duty to provide legal aid without charge to its clients, and the rationale behind the fee award would be served as well as if a private attorney had handled the case.

Finally, if only a small portion of the recovered fund is to be distributed to people in a low income category, ${ }^{331}$ it seems equitable to award fees to Legal Services when it handles such a case. Such a case minimizes the problem of Legal Services taking part of its clients' recovery, since most of those who participate in the recovery are not real or potential Legal Services clients; it is only fair that those who could afford to pay a private attorney share with Legal Services the cost of obtaining that recovery. An adjustment in the fee or in the distribution of the fund could be made so that only those who are not within Legal Services' "constituency" are taxed.

\section{A Solution}

The three preceding subsections set forth the case for the award of attorney's fees to Legal Services under the major rationales for fee awards. Many statutory provisions are grounded in one or another of these rationales. ${ }^{332}$ The remaining statutory and common law methods of awarding fees in

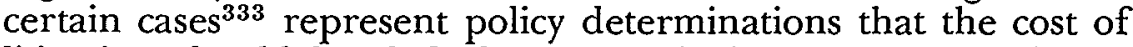
litigation should be shifted to a particular party in particular

${ }^{330} 456$ F.2d 943 (4th Cir.), cert. denied, 406 U.S. 933 (1972) (school district must provide a method of free busing as part of its desegregation plan).

It has been suggested that Brewer should have been discussed under the private attorney general rationale, id. at 952-54 (Winter, J., concurring specially), but it will be treated here as a common fund case because that is the terminology used by the court.

${ }_{331}$ One example of this would be a case in which a plaintiff represented by Legal Services recovered a monetary fund by challenging illegal price increases in a regulated industry which affected all consumers alike.

${ }_{332}$ Section 204(b) of Title II of the Civil Rights Act of 1964, 42 U.S.C. § 2000a-3(b) (1970), exemplifies the private attorney general rationale. See Newman v. Piggie Park Enterprises, Inc., 390 U.S. 400 (1968). FED. R. APP. P. 38 formalizes the sanction against frivolous appeals. See also Comment, 87 Harv. L. REv. 411, 415 (1973).

${ }^{333}$ For example, the husband must generally pay the wife's attorney's fees in matrimonial actions. See H. Glark, Law of Domestic Relations in the United States $\S$ 14.2 (1968); note 74 supra \& accompanying text. 
types of cases. Such policies are equally applicable to litigants represented by Legal Services, in that neither the taxpayer nor Legal Services should bear the cost of such an action when it has been determined to be sound policy that the opposing party bear the costs. As already noted, the opposing party should not benefit because Legal Services, and not a private attorney, handles the case. In view of the legitimate benefits provided by Legal Services and the lack of barriers to such awards, courts should routinely award attorney's fees to Legal Services whenever an award would be appropriate to a party represented by a private attorney, making an exception only in certain common fund cases. ${ }^{334}$

\section{Should It Be a Two Way Street?}

Having given the case for the award of attorney's fees to Legal Services whenever fees would be awarded to a party represented by a private attorney, the question of fee awards against Legal Services arises. The most extreme resolution of this issue is that adopted by the House of Representatives when it passed an amendment to the Legal Services Corporation Bill ${ }^{335}$ authorizing courts to award costs and.attorney's fees to any winning defendant sued by a litigant represented by a Legal Services attorney. Such fees would be paid directly by the Legal Services Corporation. ${ }^{336}$ This provision is completely one-sided (as Legal Services may not routinely collect fees in the cases it wins as plaintiff's attorney) and seems to be an attempt to limit indirectly the effectiveness of Legal Services. ${ }^{337}$

A fairer solution to this problem is found in the landmark English case of Hanning $v$. Maitland ${ }^{338}$ which set current English policy concerning a prevailing litigant who would normally collect fees, but cannot because his opponent is represented by a legal aid organization. In Hanning a cyclist sued a pedestrian for

${ }^{334}$ See notes 324-31 supra \& accompanying text.

335 H.R. 7824, 93d Cong., 1st Sess. (1973); see 119 Cong. REC. 5103 (daily ed., June $21,1973)$.

${ }^{336}$ See id. 5102.

${ }^{337}$ At least two justifications are given for this amendment. First, it is said to be inequitable for the federal government to sponsor suits against private individuals who end up paying their own attorney's fees even if they win; second, that the threat of paying fees in all losing cases would restrain Legal Services attorneys from taking frivolous cases and appeals. See id. 5103 (Remarks of Rep. Green).

Neither argument is very convincing. While it is laudable for Congress to be concerned with the burden imposed upon those who must litigate against a party subsidized by government funds, such concern has not manifested itself in other somewhat analogous cases where the individual must contend with federally supported opponents (e.g., successful criminal defendants or those who successfully sue for tax refunds). Also, it is hard to believe that frivolous litigation is a problem in an organization such as Legal Services, which only loses $12 \%$ of its cases. See id. 5109 (Remarks of Rep. Meeds, referring to a General Accounting Office report on Legal Services).

${ }^{338}[1970] 2$ W.L.R. 151 (C.A.). 
injuries incurred when he ran into the pedestrian at the road's edge. The cyclist was represented by legal aid and the pedestrian, though of very modest means, had to retain private counsel. The Legal Aid Act of 1964 provided for payment, out of the Legal Aid Fund, of costs incurred by successful opponents of legally-aided litigants where certain conditions were met: (1) that in the absence of legal aid the successful party would have been awarded costs, (2) that it be just and equitable under all the circumstances to pay costs out of public funds, and (3) that the unassisted party would suffer severe financial hardship otherwise. ${ }^{339}$ The Hanning court reinterpreted the Act so that the financial hardship criterion would exclude only the wealthy, insurance companies and prosperous corporations; and indicated that fees should be awarded in every case regardless of fault on the part of the legal aid committee or attorney. In this way a successful litigant would not be financially disadvantaged because the other party was an indigent represented by legal aid.

Although England follows the winner-take-all rule ${ }^{340}$ and the Legal Aid Fund may recover fees from a losing party just as any other litigant, ${ }^{341}$ Hanning may be relevant to American policy if read to say that legal aid organizations should be treated the same as a losing nonindigent party with regard to the award of attorney's fees against it. In the United States, applying such a rule would result in an award of fees against Legal Services only in those cases where a fee would have been awarded against a party represented by private counsel. It is evident that this policy could be fairly applied only if Legal Services could in general be awarded fees in cases where a person represented by a private attorney would receive them. Such an added financial burden on an already underfunded program could have the effect of forcing Legal Services to turn down cases which, although possibly meritorious, promise a slight chance of winning and a larger chance of an adverse fee award. Presumably, however, given the highly successful court record of Legal Services, fees recovered would more than cover those which had to be paid out. If in the case of a particular local project this favorable ratio were not established, help from the national budget would be in order so as not to jeopardize the everyday operation of that project. $^{342}$

${ }^{339} \mathrm{See}$ id. at 154 . The previously controlling precedent, Nowotnik v. Nowotnik, [1965] 3 W.L.R. 920 (C.A.), had strictly limited the use of the 1964 Act, by excluding awards to persons who would not suffer "severe financial hardship" unless the award was made and by construing "just and equitable" to mean that the winning litigant be awarded only as much as he would have gotten out of the fund if he were an assisted person. See [1970] 2 W.L.R. at 155.

${ }^{340}$ For a brief explanation of English fee award practices, see note 7 supra.

${ }^{341}$ See Jolowicz, Fundamental Guarantees in Civil Litigation: England, in Fundamental Guarantees of the Parties in Civil Litigation 121, 152 (M. Cappelletti \& D. Tallon eds. 1973).

${ }^{342}$ This problem might also be solved by awarding fees against a Legal Services 
The number of cases in which fee awards could legitimately be made against Legal Services projects under this system would probably be small, generally being limited to frivolous litigation and enforcement of contracts which include an attorney's fee clause, such as leases ${ }^{343}$ or security agreements. Such a policy, however, would open the door to the possibility that judges unfavorably disposed to Legal Services attorneys ${ }^{344}$ would award excessive fees or exercise their discretion more broadly than usual to deter certain types of suits.

Furthermore, the Legal Services-assisted indigent will seldom, if ever, be a defendant in a fee award case. For example, the strongest national policy supporting the award of fees is aimed at facilitating suits by plaintiffs where there is an important public interest involved ${ }^{345}$ and indigents are not defendants in such suits. Thus to recognize that the political frailty and limited budget of the Legal Services program are such that fees should never be awarded against local projects would not seriously impede the national policy supporting such plaintifforiented equitable and statutory exceptions to the American Rule. In the ideal world of a financially sound Legal Services program, fees could be awarded against Legal Services the same as against any private litigant. Such, however, is not the state of the Legal Services program in the United States in 1974. In addition to furthering the policies behind fee awards, awards to Legal Services would augment the meager Legal Services budget at no additional cost to the taxpayer. To partially nullify this

project only if they could be paid out of the fund created by winning fee award cases. Among people who obtained fee awards, however, this might be an unfair method of distribution because whether a particular litigant would actually get fees would depend on the status of the fund at the time of that particular fee award.

${ }^{343}$ Under New York law when there is such a clause benefiting the landlord in a lease in New York City, a covenant is implied that the landlord will have to pay the tenant's reasonable fees and costs if the tenant should prevail in litigation. See N.Y. ReAL Prop. LAW \& 234 (McKinney 1968).

${ }^{344}$ That many judges are in fact hostile to program goals and Legal Services staff attorneys is documented in Stumpf \& Janowitz, Judges and the Poor: Bench Responses to Federally Financed Legal Services, 21 STAN. L. REv. 1058 (1969).

${ }^{345}$ The rationales of private attorney general and common benefit were developed to aid only prevailing plaintiffs. The Fair Labor Standards Act, 29 U.S.C. § 216(b) (1970), the Labor-Management Reporting \& Disclosure Act, id. \$ 501(b) (1970), the Truth in Lending Act, $15 \mathrm{id}$. $\S 1640(\mathrm{a})(2)(1970)$, and the Fair Housing Act of 1968, $42 \mathrm{id}$. $\S$ 3612 (c) $(1970)$, for example, provide for the award of fees only to prevailing plaintiffs. Even where the statute is worded so as to allow fees to a prevailing plaintiff or defendant, a court may look behind the words to the purpose of the provision and decline to award fees to a winning defendant. In Richardson v. Hotel Corp., 332 F. Supp. 519 (E.D. La. 1971), aff'd, 468 F.2d 951 (5th Cir. 1972), the defendant moved for attorney's fees under such a fee provision contained in Title VII of the Civil Rights Act of 1964, 42 U.S.C. \& $2000 \mathrm{e}-5(\mathrm{k})(1970)$. The court found that the award was not justified as the plaintiff had proceeded in forma pauperis and in good faith in an attempt to vindicate statutory rights and that the award would serve only as possible "precedent in terrorem to discourage other Title VII plaintiffs." 332 F. Supp. at 521-22. But see United States v. Gray, 319 F. Supp. 871 (D.R.I. 1970) (fees awarded to successful defendant against federal government in a racial discrimination suit the court found to be meritless). 
desirable effect by awarding fees against Legal Services, even though limited to certain types of cases, would be undesirable.

\section{E. Conclusion}

In Woolfolk v. Brown ${ }^{346}$ the court suggested that in order to award fees when Legal Services is the potential recipient special public policy factors must be present, even though fees would be awarded without such additional factors if a private attorney were involved. The analysis in this Section leads to the simpler, more rational result that a court should award fees to Legal Services whenever they would be awarded to a party represented by a private attorney, with the one exception that an award would be improper if it would reduce the recovery of Legal Services clients. Such an organization is a proper recipient of fees; there is no threat of competition with the private bar; the awards would increase the legal aid available to eligible clients in a program with ambitious goals but inadequate funding; and, most significantly, only such awards can adequately and fairly accomplish the purposes sought to be achieved by the particular fee award rationale involved. Awarding fees against Legal Services, however, involves different considerations which on balance lead to the conclusion that at this time such a practice is ill-advised and not compelled by any strong policy.

At present the number and variety of cases in which attorney's fees are awarded may seem limited, so the question of awarding fees to Legal Services may not appear particularly significant. But viewed in terms of the rapid expansion of cases covered by statutory and equitable exceptions to the American Rule, and the large impact a few fee awards could have on a local Legal Services office, the issue emerges as important. A proper resolution will serve both to avoid the unjustified, inconsistent treatment of losing litigants in similar situations merely because Legal Services represents some winners, and to facilitate the enforcement of the rights of the poor through peaceful legal means. That this furthering of the aims of Legal Services is a highly desirable end was well expressed by Representative Koch in the House debates on the Legal Services Corporation Bill: ${ }^{347}$

Is it not to be preferred that there be a cutting edge for social change applied through the courts rather than through riot and upheaval in the streets, and is it not helpful in terms of testing and changing the law that those who could not afford lawyers are provided with those legal services? ${ }^{348}$

${ }^{346} 358$ F. Supp. 524 (E.D. Va. 1973).

${ }^{347}$ H.R. 7284, 93d Cong., lst Sess. (1973).

${ }^{348} 119$ ConG. REC. 5097 (daily ed., June 21, 1973). 


\section{Calculating the Fee Award}

\section{A. Introduction}

The size of a court awarded attorney's fee may seem to be of subordinate importance. Yet whether statutory or equitable principle mandates a fee award to a victorious plaintiff ${ }^{349}$ or vests in the court discretion to make such an award, ${ }^{350}$ it is the size of the fee award which will for practical purposes determine whether the underlying public purposes are to be frustrated or fulfilled. ${ }^{351}$

Ideally, litigating parties could agree upon an appropriate fee award. In the absence of agreement between the parties, the burden falls on the court to determine an appropriate fee. ${ }^{352}$ Unfortunately, the guidance accorded a conscientious trial judge in discharging this burden has been minimal. Suggestions for the proper method of assessing the "reasonable" award have ranged from awarding an amount equal to what a victorious attorney would reasonably charge his client ${ }^{353}$ to awarding the plaintiff an amount equal to the legal expenses of the defendant. ${ }^{354} \mathrm{Em}$ phasis in such proposals has varied from strict attention to the size of the plaintiff's recovery ${ }^{355}$ to nearly exclusive focus upon the number of hours spent on the case. ${ }^{356}$ Statutes have provided no more helpful calipers for reasonableness: some have confided the question to unfettered judicial discretion, ${ }^{357}$ while others have required the courts to interpret such unhelpful phrases as

${ }^{349}$ See, e.g., Clayton Act $\$ 4,15$ U.S.C. $\$ 15$ (1970).

${ }^{350}$ See, e.g., Civil Rights Act of 1964, § 204(b), 42 U.S.C. $\S 2000 \mathrm{a}-3(\mathrm{~b})$ (1970).

${ }^{351}$ See Note, supra note 97 , at 400 .

${ }^{352}$ See Jones v. Seldon's Furniture Warehouse, Inc., 357 F. Supp. 886, 888 (E.D. Va. 1973) (Truth-in-Lending); Sims v. Amos, 340 F. Supp. 691, 693 n.3 (M.D. Ala.), affd, 409 U.S. 942 (1972).

${ }^{353}$ See Cape Cod Food Products, Inc. v. National Cranberry Ass'n, 119 F. Supp. 242, 244 (D. Mass. 1954). This method, although not inconsistent with the theory of fee awards, tends to minimize downward pressure on contingent fee agreements and may lead to "sweetheart" fee arrangements between client and attorney. It has been rejected by most courts. See, e.g., Milwaukee Towne Corp. v. Loew's, Inc., 190 F.2d 561, 570 (7th Cir. 1951).

${ }^{354}$ See Memorandum in Support of Award of Expenses and Attorney's Fees at 26-27, Wilderness Soc'y v. Morton, No. 72-1796-98 (D.C. Cir., filed Feb. 23, 1973).

${ }_{355}$ See, e.g., Webster Motor Car Co. v. Packard Motor Car Co., 166 F. Supp. 865 (D.D.C. 1955), rev'd E cross-appeal concerning attorney's fee award dismissed as moot, 243 F.2d 418, 421 (D.C. Cir.), cert. denied, 355 U.S. 822 (1957). This method has been rejected by most courts on the theory that placing primary importance on the size of a recovery results in either inadequate or excessive awards. See, e.g., Trans World Airlines, Inc. v. Hughes, 312 F. Supp. 478, 484 (S.D.N.Y. 1970), aff'd with respect to fee award, 449 F.2d 51, 79 (2d Cir. 1971), rev'd on other grounds, 409 U.S. 363 (1973); Illinois v. Harper \& Row Publishers, Inc., 55 F.R.D. 221 (N.D. Ill. 1972).

${ }_{356}$ See, e.g., Perkins v. Standard Oil Co., 474 F.2d 549 (9th Cir.), cert. denied, 412 U.S. 940 (1973). Several courts have rejected this approach, finding the complexity of the legal problems and the skill and success of counsel more important considerations in measuring the value of legal services. See, e.g., Trans World Airlines, Inc. v. Hughes, 312 F. Supp. 478, 484 (S.D.N.Y. 1970), aff'd with respect to fee award, 449 F.2d 51, 79 (2d Cir. 1971), rev'd on other grounds, 409 U.S. 363 (1973).

${ }_{357}$ See, e.g., Truth-in-Lending Act $\S 130(a)(2), 15$ U.S.C. $\S 1640(a)(2)(1970)$. 
"reasonable part of the recovery." 358 Even plaintiffs or defendants as a class are unlikely to espouse a consistent philosophy regarding the factors which should govern fee awards. Where there is a large recovery a plaintiff is likely to ask for a fee award pegged to a percentage of the recovery, while the defendant will plead that an hourly rate best establishes a "reasonable" award. Where only a small recovery is involved, however, the disputants are likely to reverse positions. ${ }^{359}$

\section{B. The Vagaries of "Reasonableness"}

Current judicial practice in awarding attorney's fees fails to give close attention to fundamental purposes underlying the award of attorney's fees. ${ }^{360}$ Though current awards are made under a variety of rationales, courts do not appear even to have considered the possibility that the differing rationales could justify differing methods of fee calculation. Trial judges have frequently awarded fees without ever stating the criteria by which those fees were calculated, and appellate review of trial court awards has been as narrow as the trial court discretion has been broad. ${ }^{361}$ The clearest guiding principle that has emerged is that awards cannot be calculated by any simple formula. ${ }^{362}$

Recent cases do seem to indicate a general rejection of the philosophy which suggested that fee awards be determined by a specified percentage of a plaintiff's recovery. ${ }^{363}$ An occasional court will award fees on the basis of a percentage of assessed damages: in Jurinko v. Wiegand Co., ${ }^{364}$ for example, the court ordered that the attorneys be awarded $\$ 3,946$, or twenty-five percent of the damages suffered by their clients. This approach, however, is atypical, and is unlikely to be applied in cases in which more substantial damages are awarded.

The presently predominant method of calculating a court awarded attorney's fee is partially exemplified by a recent case involving section four of the Clayton Act, ${ }^{365}$ an old and muchlitigated provision for such awards. Victorious after a complex

\footnotetext{
${ }^{358}$ See, e.g., Labor-Management Reporting \& Disclosure Act § 501(b), 29 U.S.C. § 501 (b) (1970).

${ }_{359}$ Compare Hanover Shoe, Inc. v. United Shoe Machine Corp., 245 F. Supp. 258, 302 (M.D. Pa. 1965), vacated with respect to fee award, 377 F.2d 776, 793 (3d Cir. 1967), rev'd in part on other grounds, 392 U.S. 481 (1968), with Advance Business Systems \& Supply Co. v. SCM Corp., 287 F. Supp. 143, 160 (D. Md. 1968), affd in part E remanded for modification on other grounds, 415 F.2d 55 (4th Cir. 1969), cert. denied, 397 U.S. 920 (1970).

${ }^{360}$ See 2A J. Sutherland, Statutes \& Statutory Construction $\$ 58.06$, at 474 (4th ed. C. Sands 1973). See also Perkins v. Standard Oil Co., 474 F.2d 549, 554 (9th Cir.), cert. denied, 412 U.S. 940 (1973). (1973).

${ }^{361}$ See Kelly v. Guinn, 456 F.2d 100, 111 (9th Cir. 1972), cert. denied, 413 U.S. 919

${ }^{362}$ Weeks v. Southern Bell Tel. \& Tel. Co., 467 F.2d 95 (5th Cir. 1972).

${ }^{363}$ See note 355 supra.

3643 Fair Emp. Practices Cas. 944 (W.D. Pa. 1971).

36515 U.S.C. \& 15 (1970).
} 
trial, plaintiffs in Pacific Coast Agricultural Association v. Sunkist Growers, Inc. ${ }^{366}$ requested an award of over $\$ 250,000$. Defendants contended that reasonable fees would range between $\$ 36,000$ and $\$ 85,000$, or between fifteen and thirty-five percent of actual damages. The court, emphasizing that any fee award must depend upon the highly particular facts of a case, found eight factors relevant:

(1) whether plaintiff's counsel had the benefit of a prior judgment or decree in a case brought by the Government, (2) the standing of counsel at the bar -both counsel receiving the award and opposing counsel, (3) time and labor spent, (4) magnitude and complexity of the litigation, (5) responsibility undertaken, (6) the amount recovered, (7) the knowledge the court has of the conferences, arguments that were presented, and of work shown by the record to have been done by the plaintiff prior to trial, [and] (8) what it would be reasonable for counsel to charge a victorious plaintiff. ${ }^{\mathbf{3 6 7}}$

Without making clear exactly how it had utilized these eight criteria, the court rejected the defendant's percentage formula as creating only an illusion of fairness and precision. Instead it awarded a fee of $\$ 194,700$, finding that plaintiff's counsel had spent 3700 hours on the case, and allowing a hybrid hourly rate of $\$ 46 .^{368}$

Although Sunkist placed considerable emphasis upon the hourly rates of counsel, it is clear that most courts will not regard such rates as determinative in the computation of a fee award, partly out of fear that if final reliance were placed on such rates, "economy of time may cease to be a virtue." 369 Courts have, moreover, felt that factors other than inefficiency frequently make it necessary to discount the fee award computed by multiplying an attorney's hourly rate by the number of hours he invested in research and litigation.

Even where attorneys have reasonably claimed that their research was novel and time consuming, for example, courts have

${ }^{366}$ 1973-1 Trade Cas. I 74,523, at 94,342 (N.D. Cal. 1973).

${ }^{367}$ Id. at 94,343 (quoting Hanover Shoe, Inc. v. United Shoe Machinery Corp., 245 F. Supp. 258, 302-03 (M.D. Pa 1965), vacated with respect to fee award, 377 F.2d 776 (3d Cir. 1967), rev'd in part on other grounds, 392 U.S. 481 (1968). For an enunciation of similarly vague criteria, see Clark v. American Marine Corp., 320 F. Supp. 709, $711-12$ (E.D. La. 1970), affd, 437 F.2d 959 (5th Cir. 1971). See also Bradley v. School Bd., 53 F.R.D. 28, $42-43$ (E.D. Va. 1971), rev'd, 472 F.2d 318 (4th Cir. 1972), cert. granted, 412 U.S. 937 (1973), in which Judge Merhige also applied similar criteria, citing Campbell County y. Howard, 133 Va. 19, 112 S.E. 876 (1922) for surprisingly antiquated doctrinal support.

${ }_{368}$ The court computed this rate on a weighted average of $\$ 75$ for lead counsel, $\$ 60$ for partners, and $\$ 35-\$ 50$ for associates. 1973-1 Trade Cas. If 74,523, at 94344 n.2 (N.D. Cal. 1973).

${ }^{369}$ See Weeks v. Southern Bell Tel. \& Tel. Co., 467 F.2d 95, 98 (5th Cir. 1972) quoting Hornstein, supra note 42 , at 660 . 
noted that the absence of existing precedent, while sometimes necessitating a tedious search for analogous precedent, may on other occasions eliminate hours of research. ${ }^{\mathbf{3 7 0}}$ Others have noted that abnormal time spent in research may be regarded as an investment in legal acumen which will prove useful in later litigation..$^{371}$ Still others have noted that even attorney's fee provisions intended to promote civil rights were not designed as punitive measures which would put guilty defendants out of business, but were meant only to compensate for the cost of bringing antidiscrimination actions. On that basis, Black $v$. $B_{0 n d s^{372}}$ refused to assess even a requested $\$ 1,000$ fee against a small discriminatory cafe.

Other case law indicates that time spent researching and litigating unsuccessful claims ${ }^{373}$ or upon duplicated work ${ }^{374}$ will frequently be deducted from the actual number of hours spent on a case in arriving at the number of hours on which an attorney's fee award may be based. In Trans World Airlines $v$. Hughes, ${ }^{375}$ however, the court refused to limit an award of attorney's fees to the time and effort necessary to prove the items of damage ultimately sustained by the trier of fact. The Hughes court held that hours spent preparing other claims for which recovery was denied should be considered in the award, since recovery was not denied for failure of proof, but because the court rejected a theory of damage measurement reasonably advanced by the plaintiff. ${ }^{376}$ Since new theories of liability ${ }^{377}$ and damages are constantly evolving and frequently necessary to the continued vitality of old law, the Hughes court's position seems well-advised. A contrary result would penalize the creative,${ }^{378}$ and confuse innovation with inefficiency.

${ }^{370}$ United States v. Gray, 319 F. Supp. 871, 873 n.21 (D.R.I. 1970).

${ }^{371}$ E.g., Vogel v. Trans World Airlines, 5 Fair Emp. Practices Cas. 379 (W.D. Mo. 1971).

${ }_{372} 308$ F. Supp. 774, 776 (S.D. Ala. 1969).

${ }^{373}$ See Vandervelde v. Put and Call Brokers \& Dlrs. Ass'n, Inc., 1972 Trade Cas. If 74,034 (S.D.N.Y. 1972); Bowl America Inc. v. Fair Lanes, Inc., 299 F. Supp. 1080, 1100 (D. Md. 1969); Advance Business Systems \& Supply Co. v. SCM Corp., 287 F. Supp. 143, 161 (D. Md. 1968), aff'd छ' remanded for modification on other grounds, $415 \mathrm{~F} .2 \mathrm{~d} 55$ (4th Cir. 1969), cert. denied, 397 U.S. 920 (1970); Bergjans Farm Dairy Co. v. Sanitary Milk Producers, 241 F. Supp. 476, 489; Osborn v. Sinclair Refining Co., 207 F. Supp. 856, 864

(D. Md. 1962), rev'd E remanded on other grounds, 324 F.2d 566 (4th Cir. 1963).

${ }^{374}$ See, e.g., Pacific Coast Agric. Export Ass'n v. Sunkist Growers, Inc., 1973 Trade Cas. I 74,523, at 94,344 (N.D. Cal. 1973); Bowl America, Inc., v. Fair Lanes, Inc., 299 F. Supp. 1080, 1100 (D. Md. 1969); Advance Business Sys. \& Supply Co. v. SCM Corp., 287 F. Supp. 143, 161 (D. Md. 1968), aff'd छ' remanded for modification on other grounds, 415 F.2d 55 (4th Cir. 1969), cert. denied, 397 U.S. 920 (1970).

375312 F. Supp. 478 (S.D.N.Y. 1970), aff'd with respect to fee award, 449 F.2d 51 (2d

Cir. 1971), rev'd on other grounds, 409 U.S. 363 (1973).

${ }^{376} I d$. at $482-83$.

${ }^{377}$ See, e.g., Osborn v. Sinclair Refining Co., 207 F. Supp. 856, 864 (D. Md. 1962), rev'd E remanded on other grounds, 324 F.2d 566 (4th Cir. 1963).

${ }^{378}$ See Comment, Attorneys' Fees in Individual and Class Action Antitrust Litigation, 60

Cal. L. Rev. 1656, 1667 (1972). 
Thus, careful analysis should be used in reducing the total number of hours spent on a case to some lesser total upon which the fee award will be based. Although the cost of time spent preparing patently meritless claims will not be forced upon a defendant-even one guilty of other illegality-courts are unlikely to require an attorney to possess superhuman prescience and assess early in the history of a case the exact legal services which will prove absolutely necessary. ${ }^{379}$

The small size of a plaintiff's recovery has occasionally been found to justify reduction of a fee. ${ }^{380}$ The propriety of this practice is questionable, since it may discourage small claimants from vindicating even clear legal rights. ${ }^{381}$ Fees awarded on a private attorney general or common benefit rationale, ${ }^{382}$ in particular, are awarded for the very reason that the rights in dispute do not concern only the named parties, ${ }^{383}$ and that the monetary damages awarded in such litigation are not likely to reflect the true benefits. ${ }^{384}$ For these reasons, the limited size of a monetary recovery should not justify reduction of an otherwise "reasonable" fee award in such circumstances. It should similarly not result in the reduction of awards made under an obstinate party rationale, ${ }^{385}$ or otherwise premised upon the bad faith of the losing litigant, simply to effectuate the policies those rules embody. ${ }^{386}$

${ }^{379}$ In Locklin v. Day-Glo Color Corp., 429 F.2d 873 (7th Gir. 1970), cert. denied, 400 U.S. 1020 (1971), for example, the Seventh Circuit indicated its belief that legal services which appear unnecessary in retrospect may be considered in an award unless they were "manufactured." Id. at 878-79.

${ }^{380}$ See Schaeffer v. San Diego Yellow Cabs, Inc., 462 F.2d 1002 (9th Cir. 1972); Bates v. Hinds, 334 F. Supp. 528, 533 (N.D. Tex. 1971). Thus, in Lyle v. Teresi, 327 F. Supp. 683,686 (D. Minn. 1971), although a fee of $\$ 11,280$ would have been computed under a minimum fee schedule, the court awarded only $\$ 1,000$, noting that its damage award had been only $\$ 4,000$. But of. Ratner v. Chemical Bank, 54 F.R.D. 412 (S.D.N.Y. 1972) (parties' agreement on a sizeable settlement for attorney's fees probably influenced the court to forbid maintenance of class action, limiting attorney-plaintiff to $\$ 100$ statutory damages under Truth-in-Lending).

${ }^{381} \mathrm{Cf}$. text accompanying notes 94-96 supra.

${ }^{382}$ See text accompanying notes 325-29 supra.

${ }^{383}$ See Newman v. Piggie Park Enterprises, Inc., 390 U.S. 400, 402 (1968) (civil rights); La Raza Unida v. Volpe, 57 F.R.D. 94, 99 (N.D. Cal. 1972) (environmental).

${ }^{384}$ See Brewer v. School Bd., 456 F.2d 943, 952-53 (4th Cir.) (Winter, J., concurring), cert. denied, 409 U.S. 892 (1972); Highway Truck Drivers Local 107 v. Cohen, 220 F. Supp. 735, 737-38 (E.D. Pa. 1963) (under \$ 501(b) of the Labor-Management Reporting \& Disclosure Act, 29 U.S.C. $\$ 501$ (b) (1970), which permitted an award of a "reasonable part of the recovery," the court granted a $\$ 38,000$ fee award despite a monetary recovery under $\$ 25,000$, interpreting "recovery" to include total benefits of the litigation, not merely plaintiffs monetary relief). See also Hammond v. Housing Authority, 328 F. Supp. 586, 588 (D. Ore. 1971).

${ }^{385}$ See text accompanying notes 293-96 supra.

${ }^{386}$ See note 112 supra \& accompanying text. Two other considerations deserve mention. At one extreme, a plaintiff cannot expect any award of attorney's fees until a decision on the merits is reached. See Young v. ITT, 5 Fair Emp. Practices Cas. 19 (E.D. Pa. 1972). 


\section{A Suggested Change}

While the abstract criteria used by modern courts in calculating awards of attorney's fees are sound at the theoretical level, their very abstractness has afforded courts virtually unlimited discretion in their application. The very existence of such a multiplicity of discretionary factors has generally made it impossible to predict with any assurance what will be awarded in any particular case. The consequent difficulties of estimation are a problem not only for the practitioner but for the trial judge:

Any Court approaches the problem of an attorneys fee with trepidation. Anyone who has had the benefit of the experience of a dozen partners expressing an opinion on a fee knows that the answers are going to be a dozen, ranging hundreds of per cents apart. ${ }^{387}$

Since trial court discretion has been disturbed only upon proof of its abuse, ${ }^{388}$ and since a discussion of abstract criteria does not generally provide a record which is reviewable, ${ }^{389}$ even courts that are generous in their awards have not demonstrated consistency in measuring fees. ${ }^{390} \mathrm{~A}$ particularly troubling consequence has been the lack of consistently adequate fee awards in areas such as civil rights litigation where they are necessary to spur the private bar to active participation. ${ }^{391}$

Several commentators have suggested the need for more sharply defined standards for the awarding of attorney's fees. ${ }^{392}$ Even less significant departures from current practice, however, would not only increase consistency in attorney's fee awards, and provide awards which would reasonably reimburse plaintiffs and

At the other, a plaintiff forced to protect a damage recovery through appellate proceedings may not, at least in antitrust litigation, be entitled to the same monetary rate for appellate as for trial court work. In Perkins v. Standard Oil Co., 474 F.2d 549 (9th Cir.), cert. denied, 412 U.S. 940 (1973), for example, the Ninth Circuit declared that an award need not fully reimburse a plaintiff for his counsel fees on appeal, since such an award was made only to prevent undue shrinkage of the plaintiff's damage award from the costs of appeal. Id. at 553. Noting that antitrust litigation is most complex in its earlier stages and that fee awards on appeal should generally be less than those for trial work (the latter had been at the rate of $\$ 46$ per hour) the Ninth Circuit found an hourly rate of $\$ 40$ to reflect the contributions of various attorneys employed for the appeal, id. at 554 n.7, rejecting the district court's award for appellate services, computed at rates of over $\$ 85$ per hour. Given that a successful antitrust plaintiff will be awarded treble damages, this "undue shrinkage" argument seems inapposite to other appellate proceedings.

${ }^{387}$ Dobbins v. Local 212, IBEW, 2 Fair Emp. Practices Cas. 180 (S.D. Ohio 1969).

${ }^{388}$ See, e.g., Montague \& Co. v. Lowry, 193 U.S. 38, 48 (1904); Cato v. Parham, 403 F.2d 12, 16 (8th Cir. 1968).

${ }^{389}$ See Trans World Airlines, Inc. v. Hughes, 312 F. Supp. 478, 480-85 (S.D.N.Y. 1970), aff'd with respect to fee award, 449 F.2d 51, 79 (2d Cir. 1971), rev'd on other grounds, 409 U.S. 363 (1973).

${ }^{390}$ See Clark, The Treble Damage Bonanza: New Doctrines of Damages in Private Antitrust Suits, 52 Mrch. L. Rev. 363, 412 (1954) ("there are nearly as many notions of what is reasonable as there are judges"); Comment, supra note 378 , at 1657.

391 See Note, supra note 97 at 404 .

392 See, e.g., id., 410-11; Comment, supra note 378, at 1668. 
lawyers for the expenses of litigation, but would also provide appellate courts with the record necessary to insure that the purposes of such awards are consistently served. ${ }^{393}$ The mere requirement of a systematic application of current guidelines, for example, combined with a requirement that trial courts conduct an evidentiary hearing at which are made certain basic factual findings essential to intelligent fee awards, should allow continued broad judicial discretion, while affording practitioners some ability to predict fee awards. This systematic calculation of the fee award would, moreover, focus new attention upon the adequacy or inadequacy of such awards in attracting necessary participation by the private bar.

Appellate courts should regularly demand that trial courts conduct a brief evidentiary hearing and make specific findings concerning factors essential to a basic fee calculation. These would include: the total number of hours actually spent on a case; ${ }^{394}$ the number of hours which must be subtracted for unsubstantiated claims, wasted effort or unwarranted start-up research; ${ }^{395}$ experience, reputation and usual fees of counsel, ${ }^{396}$ and the extent and quality of their work; ${ }^{397}$ and applicable

${ }^{393}$ It should be noted that appellate courts have recently been less inhibited in remanding fee award determinations when the record provides an inadequate basis for determining the "reasonableness" of an award. See, e.g., Dillon v. Berg, 42 U.S.L.W. 2101 (filed Aug. 8, 1973). Much concern has been with excessive awards, see, e.g., Ellis v. Flying Tiger Corp., No. 71-1704 (7th Cir. 1972), but there has also been growing concern with insufficient awards. See, e.g., Lea v. Cone Mills Corp., 467 F.2d 277, 280 (4th Cir. 1972) (Winter, J., dissenting).

The Fifth Circuit, moreover, has recently gone so far as to find it an abuse of discretion for a trial court, which had unexplainedly disallowed a substantial number of attorney hours, not to have expressly considered the broad discretionary factors approved in Clark v. American Marine Co., 320 F. Supp. 709 (E.D. La. 1970), aff'd, 437 F.2d 959 (5th Cir. 1971). See note 367 supra \& accompanying text. Johnson v. Georgia Highway Express, Inc., No. 72-3294 (5th Cir., Jan. 21, 1974), vacating and remanding fee award, 5 Fair Emp. Practices Cas. 776 (N.D. Ga., Aug. 8, 1972).

${ }^{304}$ See Philadelphia v. Charles Pfizer \& Co., 345 F. Supp. 454 (S.D.N.Y. 1972) (antitrust class action settlement); Blankenship v. Boyle, 337 F. Supp. 296, 302 (D.D.C. 1972); Perkins v. Standard Oil Co., 322 F. Supp. 375 (D. Ore. 1971), modified, 474 F.2d 549 (9th Cir.), cert. denied, 412 U.S. 940 (1973).

${ }^{395}$ See Lea v. Cone Mills Corp., 467 F.2d 277, 279 (4th Cir. 1972). In making this finding, a court could rely upon the testimony of expert witnesses; in their absence, however, it would presumably be competent to make the finding itself.

${ }^{396}$ See id. at 280 (Winter, J., dissenting); United States v. Gray, 319 F. Supp. 871 (D.R.I. 1970); Cape Cod Food Prods., Inc. v. National Cranberry Ass'n, 119 F. Supp. 242, 244 (D. Mass. 1954); Note, supra note 97, at 411.

Several recent cases demonstrate judicial adjustment of hourly rates according to the experience of counsel-in particular, counsel's status in a law practice. See Pacific Coast Agric. Export Ass'n v. Sunkist Growers, Inc., 1973 Trade Cas. \ 74, 523, at 94,344 n.2 (N.D. Cal. 1973); Perkins v. Standard Oil Co., 474 F.2d 549, 553-54 (9th Cir.), cert. denied, 412 U.S. 940 (1973).

Under this formula, of course, equal success in the courtroom will not necessarily be rewarded by equal compensation: the successful fledgling attorney will receive a lesser award than a more established colleague.

${ }^{397}$ See, e.g., Rosenfeld v. Southern Pac. Co., 4 Fair Emp. Practices Cas. 72 (C.D. Cal. 1972) (court stressed the value of counsel's having quickly brought the court's attention to the legal issues); Clark v. American Marine Corp., 320 F. Supp. 709, 712 (E.D. La. 1970) 
minimum fee rates in the locality. ${ }^{398}$ Having applied these factors to compute a basic fee, the court can then apply appropriate discounting procedures, ${ }^{399}$ so long as it enumerates its reasons for doing so. Finally, the court should consider allowing additional compensation to reflect the contingent nature of such fee awards and the need to encourage particular types of litigation.

\section{The Contingency Element}

Whether the purpose of awarding attorney's fees is seen as making a litigant whole ${ }^{400}$ or as encouraging the private bar to participate actively in certain types of litigation, ${ }^{401}$ that purpose is in some measure defeated if the attorney does not receive full and fair compensation adequate to induce him to take cases on the expectation of receiving such awards. The Supreme Court noted in Newman v. Piggie Park Enterprises, Inc. ${ }^{402}$ that exceptional circumstances may warrant the denial of fee awards; so too may exceptional circumstances warrant a fee based on less than the customary charges of the private bar. ${ }^{403}$ In most instances, however, a court awarded attorney's fee should reflect not only the customary charges of the bar ${ }^{404}$ but the contingency of compensation. An attorney's compensation may be considered contingent for present purposes whenever success is prerequisite to his being paid. Whether he expects a fee award out of the defendant's pocket or the more traditional percentage of

(minimum fee rate felt insufficient to compensate counsel for handling a complex civil rights case with brevity and skill); Highway Truck Drivers Local $107 \mathrm{v}$. Cohen, $220 \mathrm{~F}$. Supp. 735, 738 (E.D. Pa. 1963) (award should reflect the fact that case was "one of first impression and required more than the usual efforts and skill on the part of counsel"); Cape Cod Food Prods., Inc. v. National Cranberry Ass'n, 119 F. Supp. 242, 244 (D. Mass. 1954) (antitrust).

398 See Lindy Bros. Builders, Inc. v. American Radiator \& Standard Sanitary Corp., 487 F.2d 161 (3d Cir. 1973). These rates would be substituted for the usual fee of counsel in cases where, for example, Community Legal Services was the plaintiff, with the result that standard charges would be unavailable. They should, moreover, act as a floor for the hourly rate component of fee awards, and be applied only where such rate component is in doubt. See Lea v. Cone Mills Corp., 467 F.2d 277, 280 (4th Cir. 1972) (Winter, J., dissenting). See also note 396 supra.

${ }_{399}$ See notes $370-74$ supra \& accompanying text.

${ }^{400}$ See text accompanying note 372 supra.

401 One purpose of fee awards is to encourage the private enforcement of public policy. See Newman v. Piggie Park Enterprises, Inc., 390 U.S. 400, 402 (1968) (Civil Rights Act of 1964); Perkins v. Standard Oil Co., 474 F.2d 549, 553 (9th Cir.), cert. denizd, 412 U.S. 940 (1973) (Clayton Act); Jones v. Seldon's Furniture Warehouse, Inc., 357 F. Supp. 886, 887 (E.D. Va. 1973) (Truth-in-Lending Act); La Raza Unida v. Volpe, 57 F.R.D. 94, 100-01 (N.D. Cal. 1972) (award under court's equitable powers in environmental action); Hutchinson v. William C. Barry, Inc., 50 F. Supp. 292, 298 (D. Mass. 1943) (Fair Labor Standards Act).

${ }_{402} 390$ U.S. 400, 402 (1968) (under Title II of the Civil Rights Act of 1964, a successful plaintiff should recover an attorney's fee "unless special circumstances would render such an award unjust").

${ }^{403}$ See Hall v. Cole, 412 U.S. 1, 9 n.13 (1973) (financial condition of defendant labor union was a proper consideration in assessing a fee award made under the court's equity power). See also note 372 supra \& accompanying text.

${ }^{404}$ See note 396 supra \& accompanying text. 
plaintiff's recovery, the economic effect is the same: if he is to earn an "average" hourly rate he must be overcompensated in successful cases to make up for unpaid losing efforts. ${ }^{405}$

The fact that compensation is dependent on recovery has not generally been reflected in court awarded attorney's fees. ${ }^{406}$ One result of this nonrecognition, in private attorney general or other public interest litigation, is that attorneys who cannot afford to absorb the lost fees are discouraged from pursuing such litigation: in cases in which only injunctive relief is at stake, victory will only assure counsel of a basic hourly-computed fee, while no fee at all will be available should the suit fail. ${ }^{407}$ If counsel is nevertheless to be induced to take such cases, the deficiency must be made up out of the client's pocket. ${ }^{408}$ Either result is likely to deter vindication of protected rights.

An attorney depends upon his fees for his livelihood. In cases in which a potential plaintiff is incapable of assuring an attorney of payment in the event of defeat, it has been the contingent fee which, for all its defects, ${ }^{409}$ has kept open the courthouse door. Payment of sums in excess of the fee which would be derived by multiplication of hours spent on a case by customary hourly rates has long been deemed reasonable by the American Bar Association, ${ }^{410}$ in recognition of the fact that an attorney will invariably have expended his efforts in other cases without recompense.

Recently, in Lindy Brothers Builders, Inc. v. American Radiator E Standard Sanitary Corp., ${ }^{411}$ the Third Circuit departed

${ }^{405}$ See Hornstein, supra note 168 , at 660 .

${ }^{406}$ But see, e.g., Angoff v. Goldfine, 270 F.2d 185, 189 (1st Cir. 1959). In Angoff, a stockholders' derivative suit, the court noted one factor to be considered in a fee award was "the contingent nature of the fees, with the accompanying risk of wasting hours of work, overhead and expenses (for it is clearly established that compensation is awarded only in the event of success)." See also Illinois v. Harper \& Row Publishers, Inc., 55 F.R.D. 221,224 (N.D. Ill. 1972).

Since a main purpose of a contingency calculation is to remove disincentives to particular types of litigation, it would seem inappropriate to make such a calculation for fees awarded under a bad faith or obstinacy exception to the American Rule, see notes 50-58, 293-98 supra \& accompanying text. Such cases would be indistinguishable from ordinary private litigation but for the bad faith of the opposing litigant. Since the expense occasioned by such bad faith will be compensated for in an hourly-calculated fee award, disallowance of the contingency multiplier will create no disincentive vis-à-vis ordinary private litigation.

${ }_{407}$ This will generally be the case where class action suits are concerned. See, e.g., Illinois v. Harper \& Row Publishers, Inc., 55 F.R.D. 221, 223 (S.D. Ill. 1972) (antitrust class action suit). Even in non-class-action antitrust litigation in which plaintiffs could afford to retain counsel at an hourly rate, a typical fee arrangement calls for compensation only upon success. See Alioto, The Economics of a Treble Damage Case, 32 ABA ANTITRUST L.J. 87, 93 (1966).

${ }^{408}$ See, e.g., Farmington Dowel Prods. Co. v. Forster Mfg. Co., 421 F.2d 61, 87 n.58

(1st Cir. 1969).

${ }^{409}$ See notes 108-11 supra \& accompanying text.

${ }^{410}$ See ABA Code of Professional Responsibinity, DR 2-106(B)(8) (1969), recognizing that the contingent nature of compensation is a factor to be considered in assessing the reasonableness of a fee.

${ }^{411} 487$ F.2d 161 (3d Cir. 1973). 
significantly from current practice to observe that a fee award based solely on hourly rates may fail to fully compensate a plaintiff when his attorney's compensation is set by contract on a contingent fee basis. In those cases in which attorney's fees are most frequently awarded-class actions, ${ }^{412}$ civil rights suits, ${ }^{413}$ and environmental suits, ${ }^{414}$ for example-the availability of this contingent fee is essential to the availability of counsel. Facing this need, the Lindy court noted the need to adjust a normal fee award by a factor based on the contingency of compensation for the plaintiff's attorney. ${ }^{415}$

The court's failure to expand upon the contingency-ofcompensation factor appears to be due to tacit recognition that that factor, albeit essential to the continued emergence of private attorneys general, is difficult to grapple with. If quantified by some mathematical schedule, such a factor could result in windfall returns for a few, and turn the legal profession into a game of odds, a mere "money getting trade."416 If it is left to the unbridled discretion of the judiciary, it may be ignored, and the frustration of private enforcement of urgent laws may continue. Nonetheless, some suggestions for the application of the contingency factor may be hazarded.

First of all, contingency factors should be computed and applied case by case. In some cases, the probability of success is so great at the outset that no adjustment in a base award would be appropriate. Courts in antitrust cases, for example, have recognized that the existence of a prior decree or judgment in a government suit so enhances the likelihood of later private success that the size of a "reasonable" fee would be less in that litigation than in a similar suit brought without the benefit of prior adjudication..$^{417}$

When, however, pertinent law is unclear at the outset of a case, ${ }^{418}$ or other factors decrease the likelihood of success on a claim, an upward adjustment in recompense will be warranted. That adjustment would be greatest in cases in which new law had

${ }^{412}$ E.g., id.

${ }^{413}$ E.g., Lyle v. Teresi, 327 F. Supp. 683 (D. Minn. 1971).

${ }^{414}$ E.g., La Raza Unida v. Volpe, 57 F.R.D. 94 (N.D. Cal. 1972).

415 Ironically, Lindy was an antitrust treble damage action, the least appealing case for adjusting fee awards based on prior contingent fee arrangements.

416 United States v. Gray, 319 F. Supp. 871 (D.R.I. 1970).

${ }^{417}$ See Philadelphia v. Charles Pfizer \& Co., 345 F. Supp. 454, 484-85 (S.D.N.Y. 1972) (antitrust class action settlement); Hanover Shoe, Inc. v. United SJ OE Machinery Corp., 245 F. Supp. 258, 302 (M.D. Pa. 1965), vacated with respect to fee award, 377 F.2d 776, 793 (3d Cir. 1967), rev'd in part on other grounds, 392 U.S. 481 (1968). See also Trans World Airlines, Inc. v. Hughes, 312 F. Supp. 478, 482 (S.D.N.Y. 1970), aff'd with respect to fee award, 449 F.2d 51, 79 (2d Cir. 1971), rev'd on other grounds, 409 U.S. 363 (1973).

${ }^{418}$ This is analogous to the perspective a court uses when determining whether a fee arrangement is ethical: it evaluates the facts known to the parties when the agreement was formed. See Farmington Dowel Prods. Co. v. Forster Mfg. Co., 421 F.2d 61, 89 (1st Cir. 1969). 
to be forged or difficult burdens of proof met, ${ }^{419}$ to encourage the private bar to take claims which, though potentially meritorious, might for economic reasons go unrepresented. ${ }^{420}$ How high the contingency multiplier factor might rise is especially problematic, and is best left to judicial development. A multiplier factor of one hundred, even in a case in which the chances of victory were one in one hundred, would be patently unreasonable; even bringing such a claim could be considered frivolous or vexatious. On the other hand, a multiplier of two would seem clearly reasonable in a case whose odds might be computed as even. Perhaps the best starting point for quantification of the contingency factor would be an empirical examination of the relationship between the maximum allowable contingent fee in a jurisdiction, and the hourly-computed fee which would be deemed reasonable in comparable cases. The ratio of the former to the latter would then be the maximum contingency multiplier in the jurisdiction in question, and would be reserved for the claims in which compensation at the outset of litigation appeared most contingent. Appropriately reduced multipliers could then be established for cases in which compensation was more assured.

\section{A Public Interest Factor}

Application of an appropriate contingency factor in private attorney general and common benefit litigation should have the salutary effect of assuring adequate recompense in such cases, and of removing any existing financial disincentives to such public interest litigation. In accordance with present practice, however, it would appear appropriate for a court to make an additional upward adjustment in compensation for attorneys who have undertaken thorny litigation especially requiring greater incentives to participation by the private bar. ${ }^{421}$ The court may place itself in the shoes of an attorney presented with the facts of the case at hand, and assess such factors as its likely unpopularity ${ }^{422}$ or the likelihood that the suit will give rise to complex or protracted litigation not likely to be lightly

${ }^{419}$ See Illinois v. Harper \& Row Publishers, Inc., 55 F.R.D. 221, 224 (N.D. Ill. 1972) (class action settlement); Blankenship v. Boyle, 337 F. Supp. 296, 302 (D.D.C. 1972).

${ }^{420}$ See generally Illinois v. Harper \& Row Publishers, Inc., 55 F.R.D. 221, 226 (N.D.

Ill. 1972) (antitrust class action settlement).

${ }_{421}$ See note 401 supra \& accompanying text; Angoff v. Goldfine, 270 F.2d 185, 189 (1st Cir. 1959) ("benefits accruing to the public from suits such as this" relevant to a fee calculation); Illinois v. Harper \& Row Publishers, Inc., 55 F.R.D. 221, 226 (N.D. Ill. 1972) (antitrust class action settlement).

${ }_{422}$ See Bradley v. School Bd., 53 F.R.D. 28, 44 (E.D. Va. 1971), rev'd, 472 F.2d 318 (4th Cir. 1972), cert. granted, 412 U.S. 937 (1973). The Bradley court noted that in civil rights litigation "the unpopularity of the causes and the likelihood of small reward discourage many lawyers even from mastering the field of law, much less accepting the cases." Id. See also NAACP v. Allen, 340 F. Supp. 703, 710 (M.D. Ala. 1972). 
undertaken. ${ }^{423}$ While certain of such cases may not involve the difficulties of proof that increase the unlikelihood of victory and, a fortiori, the contingency of compensation, they may involve special personal costs which establish a clear need to specially encourage such litigation. Even a case in which a contingency adjustment has been made may warrant this separate adjustment. It should be presumed that the application of a contingency multiplier would remove all disincentive to public interest litigation, and use of this public interest factor should be entrusted to the discretion of the court, to be applied where justice requires.

\section{Conclusion}

This brief investigation of the American system of attorney's fees reveals the confused state of relevant law. Courts and attorneys have consistently failed to fully grasp and explain the American Rule, its exceptions, and the policy goals underlying each. As a result, fees are awarded or denied with little or no regard for the real effect of an award on the behavior of live litigants.

While the present Rule may have had some rational basis in the distant past, it now seems to further no accepted judicial policy. Despite widespread recognition of this fact, no one has yet devised a fully viable alternative to the Rule. Minor modifications can only alleviate its worst effects.

Total repudiation of the American Rule without a thorough reevaluation of the goals behind fee shifting and a full investigation of the effects of various types of fee shifting upon the behavior of litigants of different economic strata would be disastrous. Pending such comprehensive investigation, however, some reforms are both possible and necessary. The expansion of the bad faith exception to allow fee shifting in cases of dilatory courtroom tactics, assertion of meritless defenses, and other unnecessary delay would at least lower the cost of litigation for the average private litigant and prevent oppressive manipulation of our legal apparatus. Awarding fees out of the public treasury in certain cases involving important issues of public policy would encourage judicial scrutiny of major governmental and business decisions. Such awards should be tailored to encourage the representation of all relevant interests before the courts so that a full and fair hearing will be had on all issues. Fee awards to Legal Services in cases otherwise appropriate for fee shifting

${ }^{423}$ See Illinois v. Harper \& Row Publishers, Inc., 55 F.R.D. 221, 226 (N.D. III. 1972); Bradley v. School Bd., 53 F.R.D. 28, 40 (E.D. Va. 1971), rev'd, 472 F.2d 318 (4th Cir. 1972), cert. granted, 412 U.S. 937 (1973) (noting technical problems in bringing a class action civil rights case). 
would generally both further the goals behind the applicable fee shifting rationale and help to provide increased legal resources for the poor, the most underrepresented group in our society. Finally, the courts can increase the effectiveness of fee shifting by carefully evaluating and clearly articulating the factors used in calculating the award, taking into account the policies underlying the award, and awarding fees sufficiently large to achieve those policies.

These reforms, which can at best alleviate the worst effects of the present system, are inadequate to achieve the goal of equal access to the courts. Given the present cost of litigation in the United States, no amount of tinkering with the system will accomplish that result. Litigation is now so expensive, and the needs of poor and middle-class litigants so great, that any further increase in fee awards would result not only in making the size of a fee the most important issue in much litigation, but in awarding attorney's fees that many parties simply could not pay.

The goal of totally equal access to the courts, then, will have to be achieved not through the reform of existing judicial doctrines, but through legislative action. Our law is so complicated, and lawyers' time so expensive, that some broad reform in these areas appears essential before this country can truly declare that its courts are equally open to all its citizens. 